\title{
ReVisão TAXoNômica das ESPÉcIES de ANTHURIUM (ARACEAE) SEÇÃo UROSPADIX SUBSEÇão FLAVESCENTIVIRIDIA ${ }^{1}$
}

\author{
Marcus A. Nadruz Coelho ${ }^{2,5}$, Jorge L. Waechter ${ }^{3}$, Simon J. Mayo ${ }^{4}$
}

Resumo

(Revisão taxonômica das espécies de Anthurium (Araceae) seção Urospadix subseção Flavescentiviridia) Apresenta-se o estudo taxonômico de 35 espécies de Anthurium seção Urospadix subseção Flavescentiviridia, com base em análises dos caracteres morfológicos vegetativos e reprodutivos, a partir de material coletado em campo e de exsicatas de diversos herbários nacionais e internacionais. A subseção caracteriza-se pela lâmina foliar de consistência membranácea a cartácea, esverdeada discolor, com nervuras secundárias geralmente impressas adaxialmente e proeminentes abaxialmente em diversos graus, são geralmente ombrófilas e esciófilas. Registros inéditos de morfologia vegetativa e reprodutiva estão sendo apresentados, especialmente em relação às bagas (A. acutum, A. urvilleanum, A. hoehnei, A. ianthinopodum, A. loefgrenii, A. longicuspidatum, A. luschnathianum, A. marense e A. mourae). Apresenta-se uma chave para identificação das espécies, descrições detalhadas, comentários sobre a distribuição geográfica, ecologia, fenologia, conservação e ilustrações para cada uma delas.

Palavras-chave: morfologia vegetativa, morfologia reprodutiva, floresta atlântica, costa atlântica.

\section{Abstract}

(Taxonomic revision of Anthurium sect. Urospadix subsect. Flavescentiviridia (Araceae)) A taxonomic revision of the 35 species of Anthurium sect. Urospadix subsect. Flavescentiviridia is presented, it was based on vegetative and reproductive morphological characters data gathered during field studies and the analyses of dried specimens from herbaria in Brazil and abroad. The subsection is characterized primarily by vegetative characters, mainly from the leaves. Unreported morphological observations are presented, being particularly interesting those concerned to the fruits of A. acutum, A. urvilleanum, A. hoehnei, A. ianthinopodum, A. loefgrenii, A. longicuspidatum, A. luschnathianum, A. marense and A. mourae. An identification key is provided for the species as well as illustrations, detailed descriptions and commentary on geographical distribution, ecology, phenology and conservation status for each species.

Key words: vegetative morphology, reproductive morphology, atlantic forest, atlantic coast.

\section{INTRODUÇÃo}

Araceae está dividida em 10 subfamílias (Bogner \& Hesse 2005), possuindo 113 gêneros (CATE Araceae 2009) e cerca de 4.000 espécies, distribuídas pela América tropical e Norte, África tropical continental e Sul, Eurásia temperada, Arquipélago Malaio, Madagascar e Seychelles (Mayo 1997).

O gênero Anthurium é o maior da família, com cerca de 1.100 espécies. Sua área de distribuição é essencialmente a América tropical, distribuindo-se do México até a Argentina, ocorrendo também nas ilhas do
Caribe (Mayo 1997). Apresenta grande diversidade nas matas úmidas tropicais de baixas e médias elevações, mas também ocorrem em florestas nebulares, em áreas brejosas, sobre afloramentos rochosos, áreas arenosas abertas e até em regiões semi-áridas. As espécies são hemiepífitas trepadeiras, terrestres, epífitas, litófitas, raramente helófitas ou reófitas (Mayo 1997). Na última grande revisão do gênero (Engler 1905), as 486 espécies foram agrupadas em 18 seções. Atualmente o gênero Anthurium pertence a subfamília Pothoideae, tribo Potheae e está

Artigo recebido em 01/2008. Aceito para publicação em 11/2009.

${ }^{1}$ Parte da Tese de Doutorado defendida no Programa de Pós Graduação em Botânica da Universidade Federal do Rio Grande do Sul.

${ }^{2}$ Instituto de Pesquisas Jardim Botânico do Rio de Janeiro, R. Pacheco Leão 915, 22460-030, Rio de Janeiro, RJ.

${ }^{3}$ Universidade Federal do Rio Grande do Sul, Av. Bento Gonçalves 9500, Prédio 43433, bl. 4, s. 214, Campus do Vale, 91501-970, Porto Alegre, RS.

${ }^{4}$ Royal Botanic Gardens Kew, Richmond, Surrey, TW9 3AB, London, England.

${ }^{5}$ Autor para correspondência: mnadruz@jbrj.gov.br 
subdividido em 19 seções (Croat 1983; Keating 2002).

Poucos trabalhos foram desenvolvidos com o gênero Anthurium desde o tratamento de Engler (1905), principalmente no leste do Brasil, onde, a excessão de algumas espécies descritas (e.g. Barroso 1957; Catharino 1990; Sakuragui 1999; Coelho 2000, 2004, 2006; Gonçalves 2005), floras realizadas (Coelho 2000) e estudos relacionados à morfologia (Madison 1978; Croat 1979, 1991), muitos táxons ainda são pobremente definidos e pouco compreendidos, necessitando ainda de estudos sistemáticos (Croat 2000).

A seção Urospadix foi descrita por Engler (1878) para agrupar 23 espécies, das quais 14 ocorrem no sudeste brasileiro. É o maior grupo, sendo o mais artificial do gênero (Croat 1983). As espécies estão concentradas no Brasil leste e sudeste. A classificação atual das seções de Anthurium é bastante similar a de Engler (1905). As espécies da seção Urospadix são reconhecidas devido aos entrenós curtos, catafilos e profilos na maioria das vezes decompostos, lâmina foliar geralmente oblongo-lanceolada, lanceolada, linear lanceolada, mais longa que larga, nervuras secundárias geralmente numerosas, evidentes e bagas subglobosas (Engler 1878, Croat 1983). Em 1898, Engler apresentou uma classificação infraseccional, criando cinco subseções para Urospadix, incluindo a subseção (§) Flavescentiviridia que reunia 21 táxons, sendo 11 para a Região Sudeste, caracterizando-se pelas lâminas foliares crassas, pouco crassas ou raramente membranáceas, de coloração pálida abaxialmente e nervuras secundárias, em material seco, proeminentes na face inferior. No tratamento de 1905, Engler, descreveu mais duas subseções, aumentando para sete o total para a seção Urospadix, sendo que 32 espécies foram reconhecidas para a subseção (§) Flavescentiviridia.

No passado, a dificuldade em posicionar taxonomicamente os espécimes desse grupo, deveu-se ao pouco conhecimento da morfologia apresentado por Engler (1905). As descrições utilizadas na citada revisão foram baseadas em diagnoses confeccionadas em tratamentos anteriores, na utilização de um pequeno número de exsicatas e por algumas coletas que foram cultivadas em estufas da Europa. Deste modo, a escassez de dados críticos como hábito, cor e grau de decomposição dos catafilos e profilos, coloração da espata e espádice, forma e cor das bagas, careceram nas descrições apresentadas, características essas necessárias para uma visão mais completa da base morfológica. Então, este trabalho tem como objetivo o estudo taxonômico da subseção (§) Flavescentiviridia no Brasil, disponibilizando dados inéditos de morfologia vegetativa e reprodutiva, até então desconhecidos ou pouco conhecidos.

\section{Material e Métodos}

Foi consultada literatura especializada (Engler 1905; Reitz 1957; Barroso 1959/61; Angely 1965; Coelho 2000) para aquisição dos primeiros registros de ocorrência das espécies da subseção Flavescentiviridia.

Para o desenvolvimento dos trabalhos de campo foram realizadas 45 viagens por 23 municípios, englobando os estados do Espírito Santo, Rio de Janeiro, Minas Gerais e São Paulo, durante o período de julho de 2000 a março de 2007. Foram coletados, seguindo as técnicas apresentadas por Croat (1985), aproximadamente 300 espécimes que encontram-se depositados no Herbário do Instituto de Pesquisas Jardim Botânico do Rio de Janeiro (RB), sendo que cerca de 200 espécimes estão em cultivo no Arboreto da mesma instituição. Foram analisadas cerca de 1.500 exsicatas procedentes de oito estados (Santa Catarina, Paraná, São Paulo, Minas Gerais, Rio de Janeiro, Espírito Santo, Bahia e Sergipe), que estão depositadas nos seguintes herbários: ALCB, B, BH, BHCB, BM, BOTU, BR, CEPEC, CESJ, ESA, F, FFP, FUEL, GFJP, GH, GUA, HB, HBR, HRCB, HUEFS, K, L, MBM, MBML, MO, NY, P, R, RB, S, SP, UB, UNISA, UPCB, UPS, US, USC (acrônimos de acordo com Holmgren \& Holmgren 1998). 
Para a nomenclatura das nervuras seguiuse Hickey (1973). As descrições das formas da lâmina foliar basearam-se em Stearn (1993). Para as formas dos seios e lobos foliares, as nervuras mediana e secundárias, os ângulos formando pela espata em relação ao pedúnculo, as decorrências da espata e as formas do espádice utilizou-se Croat (1979).

Para a realização das medidas de largura da lâmina foliar e espata, diâmetro do pecíolo, pedúnculo e espádice, e a distância da nervura coletora em relação à margem da lâmina foliar, foram utilizados as porções medianas de cada órgão. No caso das lâminas sagitadas e subhastadas a área utilizada para a medição da largura foi a junção da base da lâmina com o genículo. As larguras mensuradas do catafilo e profilo foram realizadas na porção basal desses órgãos. O uso dos termos nervuras basioscópicas e acroscópicas e os conceitos de terrestre, rupícola, hemiepífita e epífita, utilizados no texto, foram baseados em Mayo et al. (1997).

O uso da interrogação entre parênteses (?) nas descrições das espécies, refere-se à dúvida em relação à forma do órgão em material herborizado.

As cores mencionadas para os órgãos vegetativos e reprodutivos foram baseadas em material vivo e informações de etiquetas de herbário. As cores foram denominadas de forma generalizada (ex. esverdeada, amarelada, vinácea, etc.), tendo em vista a variação no tom observada em cada uma delas.

As dimensões e formas dos caracteres florais, das bagas e as formas do catafilo e profilo, foram discutidas nos resultados, não sendo apresentadas para cada espécie estudada, tendo em vista esses aspectos morfológicos repetirem-se em todas as espécies.

Na relação do material selecionado foram relatados somente os dois registros mais recentes para cada município, sendo que todas as exsicatas utilizadas foram arroladas no final do trabalho em "listagem de coletores".

A terminologia do sistema de classificação da vegetação utilizada seguiu Veloso (1991).

\section{Resultados E Discussão Morfologia}

As espécies de Anthurium, subseção Flavescentiviridia, apresentam-se como terrestres, epifíticas, hemiepifíticas ou rupícolas. No caule, os entrenós variam de muito curtos até moderadamente curtos a longos.

Foram encontradas três tipos de folhas nas espécies de Anthurium, subseção Flavescentiviridia, o mesmo ocorrendo com demais espécies da seção Urospadix: profilo, catafilo e a folha do ramo. O pecíolo, não incluindo o genículo na parte apical na junção com a base da lâmina, é reconhecido por ser um dos mais úteis caracteres taxonômicos, variando entre um e $80 \mathrm{~cm}$ compr., sendo menores ou maiores que as lâminas foliares. Quando o pecíolo é completamente circular é denominado "cilíndrico", mas quando somente uma das faces apresenta essa forma é denominado "obtuso". A forma em seção transversal é diversa, sendo encontrados seis padrões distintos nas espécies estudadas.

A lâmina foliar possui um conjunto de características diagnósticas, auxiliando na diferenciação de espécies: cor, textura, forma e presença ou ausência de pontuações glandulares. Os tipos de nervuras encontrados nas espécies de Anthurium subseção Flavescentiviridia são aquelas mencionadas para a seção Urospadix: nervura mediana, nervuras secundárias, nervura coletora e nervuras basais (em espécies com lobos posteriores).

A inflorescência nas espécies da subseção Flavescentiviridia é composta por pedúnculo, espata e espádice. Em algumas espécies a presença de estípite (região entre a inserção da espata no pedúnculo e a base da espádice) pode estar presente. Em todos os táxons estudados somente uma inflorescência se forma na axila do pecíolo. As características florais das espécies da subseção Flavescentiviridia não são consideradas úteis na taxonomia do grupo, por serem pouco consistentes na distinção de grupos ou de espécies. 
Os frutos no gênero Anthurium, como um todo, são do tipo baga, possuindo forma globosa, comportando geralmente duas sementes. As bagas apresentam diferença nas cores, auxiliando na taxonomia do grupo. As sementes podem apresentar formas e cores variadas, sendo globosas, obovadas, oblongas a reniformes, achatadas unilateralmente, arredondadas em ambas as extremidades a côncava no ápice e truncada na base, verrugosas, amareladas a vináceas, pardacentas e amarronzadas (provavelmente em sementes passadas) e envoltas por mucilagem hialina viscosa.

\section{TAXoNomia}

Anthurium Schott Wein. Zeitschr. Kunst 3:828. 1829 (3rd Quart). LECTÓTIPO: Anthurium acaule (Jacq.) Schott.

Basiônimo: Pothos acaulis Jacq., Enum. syst. pl. 31. 1760.

Caule ereto a decumbente; entrenós muito curtos a curtos, inferiores cobertos com catafilos e profilos decompostos como estopas, decíduos ou persistentes; pecíolo obtuso ou cilíndrico em seção transversal, frequentemente sulcado ou canaliculado adaxialmente, às vezes carenado abaxialmente, mais ou menos curto ou do mesmo comprimento da lâmina, provido de genículo curto ou longo; lâmina foliar com prefoliação supervoluta, inteira, lanceolada, oblonga, elíptica, ovada, raramente peltada, podendo ser aguda, cilíndrica, cordada, sagitada a hastada na base, esverdeada, coriácea, cartácea a membranácea, com ou sem pontuações glandulares em uma ou ambas as faces; nervura mediana muito proeminente, variando de obtusa a carenada em ambas as faces da lâmina foliar; nervuras secundárias numerosas unidas numa nervura coletora em cada lado da lâmina foliar, visíveis a obscuras, mais proeminentes que as nervuras terciárias; pedúnculo longo; espata geralmente linearlanceolada, raramente ovado-lanceolada, esverdeada ou avermelhada; espádice geralmente miosuróide, raramente cilíndrico, frequentemente mais longo que a espata, séssil ou às vezes longamente estipitado; flores geralmente pequenas, esverdeadas a violáceas, ovário curtamente ovóide, oblongo, coroado por um estigma largamente discóide, lóculos 1(-2)-ovulados; baga subglobosa, esverdeada, amarelada, avermelhada, violácea ou vinosa, às vezes apenas no ápice.

\section{Chave para as subseções de Urospadix (com base em Engler 1898, 1905)}

1. Lâmina foliar coriácea.

2. Nervuras secundárias visíveis.

3. Folha ereta.

4. Nervuras secundárias fortemente insculpidas adaxialmente .. §Insculptineriva

4'. Nervuras secundárias bem desenvolvidas, muito proeminentes abaxialmente .....

3'. Folha deflexa .... $\S$ Validinervia

2’. Nervuras secundárias não visíveis ........................ $\S$ Dependentia

1’. Lâmina foliar cartácea ou membranácea.
5. Lâmina foliar esverdeada concolor com nervuras secundárias pouco visíveis §Occultinervia

5'. Lâmina foliar esverdeada discolor com nervuras secundárias visíveis.

6. Nervuras secundárias 5-29, espata esverdeada a vinácea, espádice esverdeado a vináceo §Flavescentiviridia

6’. Nervuras secundárias 3-4, espata esbranquiçada, espádice lavanda ... §Paucinervia 
Anthurium seção Urospadix subseção Flavescentiviridia Engl., Bot. Jahrb. (25): 393-417 (1898). Espécie Tipo: Anthurium harrisii (Graham) G.Don., Hort. Brit., ed. 3: 633. 1839.

Caule ereto, decumbente; catafilos e profilos inteiros no ápice, inteiros a decompostos para a base do caule; pecíolo obtuso a carenado abaxialmente, obtuso, achatado, canaliculado a sulcado com margens obtusas a carenadas adaxialmente; lâmina foliar geralmente discolor, cartácea a membranácea, linear-lanceolada, lanceolada, oblonga, ovada, sagitada, subhastada e peltada, mais longa que larga; nervura mediana obtusa, aguda a carenada em ambas as faces da lâmina foliar; nervura secundárias geralmente impressas adaxialmente, proeminentes abaxialmente, mais salientes que as nervuras terciárias, 5-29; pedúnculo cilíndrico a carenado; espata esverdeada a vinácea, linear-lanceolada a lanceolada; espádice esverdeado a vináceo, cilíndrico a afunilado.

\section{Chave para as espécies de Anthurium seção Urospadix subseção Flavescentiviridia}

1. Lâminas foliares deflexas a perpendiculares em relação ao caule.

2. Lâminas foliares sagitadas ou subhastadas.

3. Lâminas foliares sagitadas; nervuras secundárias 5-11.

4. Nervura mediana aguda adaxialmente e geralmente obtusa abaxialmente; com seio rômbico; nervura basal 1 para cada lobo posterior 1. A. acutum

4'. Nervura mediana aguda em ambas as faces da lâmina foliar; com seio parabólico; nervuras basais 2 para cada lobo posterior 35. A. victorii

3’. Lâminas foliares subhastadas; nervuras secundárias 15-16 ........... 29. A. pilonense

2'. Lâminas foliares ovadas, lanceoladas ou linear-lanceoladas.

5. Nervuras secundárias fortemente impressas adaxialmente e proeminentes abaxialmente, dando aparência bulada à face laminar.

6. Pecíolo achatado a canaliculado com margens agudas a subcarenadas adaxialmente, espata navicular formando ângulo reto com o pedúnculo

33. A. unense

6'. Pecíolo cilíndrico a levemente sulcado com margens obtusas adaxialmente, espata aplanada formando ângulo agudo com o pedúnculo

7. A. fontellanus

5'. Nervuras secundárias impressas adaxialmente e proeminentes abaxialmente (não fortemente), superfície da lâmina não bulada.

7. Lâmina foliar ovada.

8. Lâmina com base arredondada a emarginada, peltada, espádice séssil a subséssil

9. Lâmina foliar cartácea, plana, deflexa, base arredondada

15. A. jureianum

9’. Lâmina foliar coriácea, navicular, perpendicular, base subtruncada a emarginada 25. A. navicularis

8'. Lâmina com base cordada, nunca peltada, espádice estipitado.

10. Lâmina estreitamente ovada levemente pruinosa abaxialmente, espata navicular 3. A. bocainense

10’. Lâmina ovada não pruinosa abaxialmente, espata aplanada 28. A. parvum

7’. Lâmina foliar linear-lanceolada a lanceolada.

11. Espécies epifíticas ou hemiepifíticas; lâminas geralmente linear-lanceoladas.

12. Espécies geralmente epifíticas; pecíolo achatado a sulcado adaxialmente; espata 0,2-0,9 cm larg., decorrência da espata 0,1-1,4 cm compr. ..... 19. A. longifolium 
12'. Espécie hemiepifítica; pecíolo cilíndrico; espata 0,7-1,2 cm larg., decorrência da espata $1,5-1,7 \mathrm{~cm}$ compr. 16. A. langsdorffii

11’. Espécie geralmente terrestre ou rupícola; lâminas lanceoladas 24. A. mourae

1’. Lâminas foliares eretas a suberetas em relação ao caule.

13. Lâminas foliares com pontos glandulares.

14. Lâmina foliar elíptica, ovado-lanceolada a ovada com base geralmente cordada as vezes truncada, raramente arredondada, presença de seio.

11. A. hoehnei

14'. Lâmina foliar subobovada, lanceolada a elíptica com base obtusa a truncada, ausência de seio

22. A. marense

13’. Lâminas foliares sem pontos glandulares.

15. Espécies geralmente terrestres ou rupícolas.

16. Caule decumbente.

17. Catafilos e profilos geralmente decompostos em direção à base do caule; pecíolo geralmente achatado adaxialmente; lâmina foliar elíptica a lanceolada com base cuneado-estreitada (São Paulo a Santa Catarina) 17. A. loefgrenii

17'. Catafilos e profilos geralmente inteiros em direção à base do caule; pecíolo sulcado a canaliculado adaxialmente; lâmina foliar lanceolada, oblonga, subovada, lanceolado-ovada a ovada, com base subaguda, arredondada, truncada, subcordada a cordada (Sergipe, Bahia e Rio de Janeiro).

18. Catafilos e profilos inteiros a levemente decompostos no ápice e em direção à base do caule, rosados, avermelhados, ferrugíneos, acastanhados a cor de palha; nervuras secundárias fortemente impressas adaxialmente e fortemente proeminentes abaxialmente; estípite 0,35-1,1 cm compr. (Sergipe e Bahia) 2. A. bellum

18'. Catafilos e profilos inteiros no ápice e em direção à base do caule, esverdeados a acastanhados; nervuras secundárias levemente impressas adaxialmente, levemente proeminentes abaxialmente a pouco visíveis em ambas as faces; estípite 0,2-0,3 cm compr. (Rio de Janeiro)

21. A. luschnathianum

16'. Caule ereto.

19. Pecíolo cilíndrico a achatado, canaliculado a sulcado, com margens obtusas a raramente agudas adaxialmente.

20. Base da lâmina foliar geralmente obtusa, raramente subcordada a truncada.

21. Nervuras secundárias visíveis em ambas as faces, sendo visivelmente impressas adaxialmente e proeminentes abaxialmente

20. A. lucioi

21'. Nervuras secundárias pouco visíveis em ambas as faces, sendo fracamente impressas adaxialmente e proeminentes abaxialmente.

22. Catafilos e profilos geralmente persistentes em direção à base do caule; lâmina foliar lanceolada a elíptica ... 27. A. parasiticum

22'.Catafilos e profilos caducos para a base do caule; lâmina foliar linear-lanceolada a oblonga.

23. Lâminas foliares linear-lanceoladas sem nervuras basais, nervuras secundárias 6-17.

24. Entrenós acima de 0,3 cm compr.; espádice estipitado 26. A. organense

24’.Entrenós até 0,2 cm compr.; espádice séssil 8. A. fragae 
23’. Lâmina foliar oblonga com 1-2 nervuras basais, nervuras secundárias 6-10 ... 30. A. regnellianum

20’. Base da lâmina foliar geralmente aguda a cuneada.

25. Lâmina foliar geralmente lanceolada.

26. Nervuras secundárias levemente visíveis a impressas adaxialmente, levemente proeminentes a proeminentes abaxialmente; espata formando ângulo agudo a obtuso com o pedúnculo, com decorrência de 0,1 a 2 cm compr.

27. Lâmina foliar subcartácea a membranácea, levemente mais estreitada em direção ao ápice, até $20 \mathrm{~cm}$ compr.; nervura mediana aguda adaxialmente; bagas com máculas avermelhadas no ápice e esverdeados para a base (São Paulo e Rio de Janeiro) ..... 18. A. longicuspidatum

27’. Lâmina foliar cartácea, levemente mais estreitada em direção a base, até $67 \mathrm{~cm}$ compr.; nervura mediana obtusa adaxialmente; bagas pretopurpurescentes no ápice e esverdeadas a esbranquiçadas para a base (Espírito Santo e Bahia) 12. A. ianthinopodum

26’. Nervuras secundárias levemente impressas a pouco visíveis adaxialmente, levemente visíveis a obscuras abaxialmente; espata formando ângulo reto com o pedúnculo

4. A. boudetii

25’. Lâmina foliar geralmente elíptica.

28. Pedúnculo até $11 \mathrm{~cm}$ compr., espata navicular, espádice com estípite de $0,2-0,5$ cm compr. 5. A. bragae

28’. Pedúnculo maior que $11 \mathrm{~cm}$ compr., espata plana, espádice séssil

23. A. miquelianum

19'. Pecíolo achatado a sulcado, com margens agudas a carenadas adaxialmente.

29. Bagas vináceas no ápice e esverdeadas a esbranquiçadas para a base

30. Lâmina foliar geralmente acastanhada quando seca, base da lâmina foliar cuneada

(Rio de Janeiro, São Paulo, Paraná e Santa Catarina) 34. A. urvilleanum

30’. Lâmina foliar nunca acastanhada quando seca, base da lâmina foliar geralmente obtusa (Rio de Janeiro) 32. A. simonii

29’. Bagas inteiramente esverdeadas.

31. Base da lâmina foliar aguda a cuneada, nervura mediana geralmente obtusa adaxialmente, em matas de encosta atlântica 13. A. intermedium

31'. Base da lâmina foliar geralmente obtusa a subtruncada, nervura mediana geralmente aguda adaxialmente, em matas de restinga ou em costões rochosos próximo ao mar 10. A. harrisii

15’. Espécies geralmente hemiepífitas ou epífitas.

32. Base da lâmina foliar geralmente longo-cuneada; bagas arroxeado-avermelhadas

14. A. jilekii

32'. Base da lâmina foliar geralmente obtusa a subtruncada; bagas esverdeadas a amareladas

33. Lâmina foliar fortemente discolor sendo esverdeado-amarelada na face abaxial; espata geralmente caduca e espádice cor-de-palha após antese 6. A. comtum

33’. Lâmina foliar não fortemente discolor, de coloração esverdeada em ambas as faces; espata persistente e espádice avermelhado a acastanhado após antese.

34. Pecíolo levemente canaliculado com margens subagudas adaxialmente; pedúnculo cilíndrico; estípite até $0,3 \mathrm{~cm}$ compr. (Espírito Santo) 9. A. gomesianum

34'. Pecíolo achatado a raramente sulcado e com margens agudas a ligeiramente carenadas adaxialmente; pedúnculo geralmente 1-6 carenado; estípite até 0,6 cm compr. (Minas Gerais, Rio de Janeiro, São Paulo, Paraná e Santa Catarina) ...31. A. sellowianum 
1. Anthurium acutum N.E. Br., Gard. Chron. 3 ser. 2: 776. 1887. Tipo: BRASIL, RIO DE JANEIRO, cult. W.W. Bull, 11.VIII.1887, N.E. Brown s.n. (holótipo - K!).

Fig. 1a-b

Terrestre; caule ereto; entrenós 2,5-7,5 mm compr.; catafilos e profilos esverdeados, acastanhados, cor-de-palha, inteiros a levemente decompostos no ápice, levemente decompostos a decompostos, persistentes a caducos para a base do caule, $1,5-7,5 \times 1,65 \mathrm{~cm}$; bainha 0,6 $3 \mathrm{~cm}$ compr.; pecíolo esverdeado tornandose vináceo na base, cilíndrico, 20,2-64,95 × 0,25-0,4 cm; genículo concolor, do mesmo diâmetro a levemente mais claro e mais espesso que o pecíolo, 0,6-2 cm compr.; lâmina foliar esverdeada, levemente discolor, geralmente membranácea a cartácea em material seco e vivo, deflexa, não pruinosa abaxialmente, pontos glandulares ausentes, sagitada, ápice rostrado, obtuso-acuminado, base com seio rômbico, 13,6-45,15 × 6,1-16,7 cm; nervura basal 1 para cada lobo posterior, lobos posteriores oblongos, obtusos, direcionados para baixo, nervura acroscópica-1 e basioscópicas-2-3; nervura mediana aguda adaxialmente, obtusa em sua totalidade a obtusa na extremidade basal do lobo anterior e aguda no restante abaxialmente; nervuras secundárias, no lobo anterior, 5-11 pares, tênues a raro levemente proeminentes abaxialmente, quase imperceptíveis adaxialmente; nervuras coletoras saindo da base laminar a raramente acima dela, 0,3-1,4 cm afastadas da margem; pedúnculo esverdeado, amarelado quando senescente, cilíndrico a raramente elipsóide, 12,3-89,4 × 0,2-0,3 cm; espata esverdeada a vinácea, ereta a subdeflexa, membranácea a cartácea, linear-lanceolada a lanceolada, formando ângulo obtuso a agudo com o pedúnculo, 2,5-9,9 ×0,3-1,1 cm, decorrência 2-4 mm compr.; espádice séssil a estipitado, esverdeado, vináceo a acastanhado, cilíndrico a subafunilado, 2,3-11,8 $\times 0,4-0,7 \mathrm{~cm}$, estípite esverdeado, 2-7 mm comp.; bagas jovens totalmente esverdeadas ou com ápice ligeiramente vináceo a cor-de-palha.

Material selecionado: BRASIL. PARANÁ: Morretes, 4.XII.1959, fl., G. Hatschbach s.n. (HBR, MBM, RB 105547). Paranaguá, 20.VI.1998, fl., J.M.
Silva et al. 2406 (BHCB, MBM); 29.II.2002, fl., O.S. Ribas et al. 4329 (MBM). Piraquara, 3.VI.1970, fl., G. Hatschbach 24390 (MBM). São José dos Pinhais, 18.IX.1998, fl., S.B. Barbosa et al. 128 (MBM); 21.I.1999, fl., J. Cordeiro et al. 1513 (MBM). SANTA CATARINA:Antonio Carlos, 16.V.98, fl., G. Martinelli et al. 14961 (RB). Blumenau, 23.IV.1953, fl., R. Reitz et al. 561 (HBR). Botuverá, 25.VII.1966, fl., R. Reitz et al. 18003 (HBR). Itajaí, 20.I.1953, fl., R. Reitz 5176 (HBR). Palhoça, 24.II.1956, fl., R. Reitz et al. 2792 (HBR). Presidente Nereu, 17.VII.1957, fl., R. Reitz et al. 4512 (HBR). SÃO PAULO: Cabeceiras do Rio Cotia, 12.VII.1933 fl., F.C. Hoehne s.n. (RB 95703); 29.XI.2002, fl., V.M. Higashi et al. 8 (UNISA). Barra do Turvo, 6.IV.2002, fr., O.S. Ribas et al. 4615 (MBM). Cajati, 30.IX.2002, fl., J.M. Silva et al. 3653 (MBM). Capão Bonito, 23.IX.1992, fl., M.M. Kirizawa et al. 2714 (SP). Cotia, 1.IX.1998, fl., E.L.M. Catharino et al. 2303 (SP). Cubatão, 13.XII.1988, fl., M.M. Kirizawa et al. 2123 (SP). Eldorado, 2.IX.1995, fl., V.C. Souza et al. 8990 (ESA, SP). Santo André, 11.III.2003, fl. e fr., M. Nadruz et al. 1555 (RB). São Paulo, 12.VII.1933, fl., F.C. Hoehne 39816 (NY).

Espécie reconhecida pelo hábito terrestre e pela lâmina foliar sagitada. Possui semelhança com A. pilonense, de quem se diferencia principalmente por apresentar lâmina foliar sagitada com base não curtamente estreitada, seio anguloso e nervuras secundárias 5-11, contra lâmina foliar subhastada com base curtamente estreitada, seio arqueado e nervuras secundárias 15-16.

Anthurium acutum tem sua distribuição de São Paulo até Santa Catarina, limite sul da subseção Flavescentiviridia. Ocorre em vegetação atlântica submontana e montana, variando de 300-1100 m de altitude, em áreas sombreadas a pouco sombreadas, úmidas e sempre com o hábito terrestre. Floresce de janeiro a dezembro e frutifica nos meses de março e abril.

2. Anthurium bellum Schott, Oesterr. Bot. Z. 9: 100. 1859. Tipo: BRASIL, BAHIA, Castelnovo, XII.1821, L. Riedel 567 (holótipo - LE†). Schott Icone Aroideae n. 567 A (lectótipo - W!, designado aqui).

Fig. 1c

[Anthurium bahiense N.E.Br. ex Engl. in A.D.C. \& C.DC., Monogr. Phan. 2: 638. 1879, nom. nud.] 

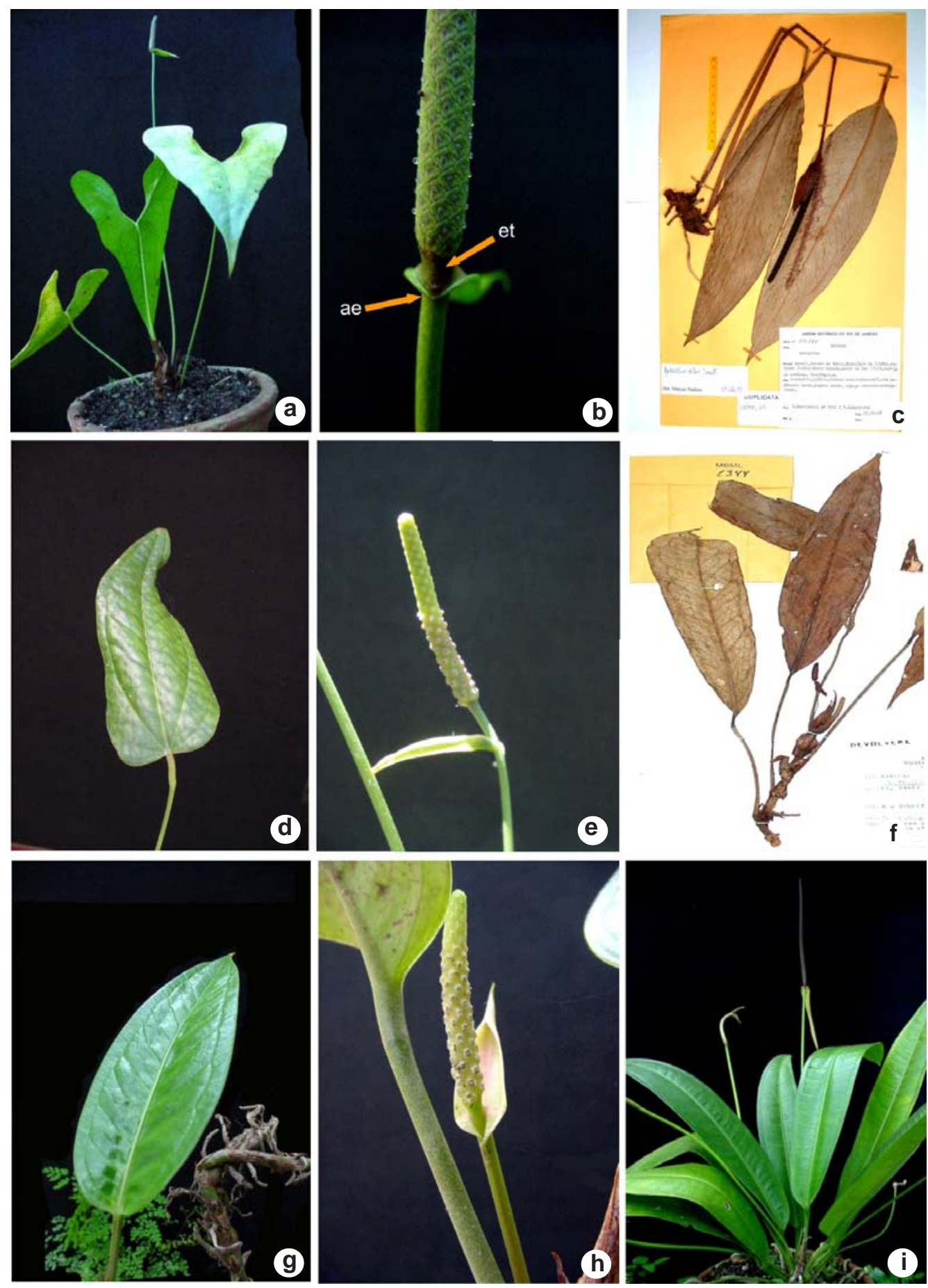

Figura 1 -a-b. Anthurium acutum -a. hábito; b. detalhe da inflorescência, evidenciando estípite (et) e o ângulo obtuso da espata em relação ao pedúnculo (ae) (Catharino s/n cultivado JBRJ). c. A. bellum - c. hábito (Martinelli 9704). d-e. A. bocainense - d. lâmina foliar; e. inflorescência (Nadruz 1685 cultivado no JBRJ). f. A. boudetii - f. hábito (Fernandes 1344). g-h. A. bragaeg. folha; h. inflorescência (Nadruz 1450 cultivado no JBRJ). i. A. comtum - i. hábito (Nadruz 1402 cultivado no JBRJ).

Figura 1 - a-b. Anthurium acutum - a. habit; b. detail of the inflorescence, showing stipe (et) the obtuse angle between the spathe and peduncle (ae) (Catharino s/n cultivated at the JBRJ). c. A. bellum - c. habit (Martinelli 9704). d-e. A. bocainense - d. leaf blade, e. inflorescence (Nadruz 1685 cultivated at JBRJ). f. A. boudetii - f. habit (Fernandes 1344). g-h. A. bragae - g. leaf; h. inflorescence (Nadruz 1450 cultivated at JBRJ). i. A. comtum - i. habit (Nadruz 1402 cultivated at JBRJ). 
Anthurium blanchetianum Engl., Pflanzenr. 21: 168. 1905. Tipo: Südbrasilianische Provinz: Bahia. J.S. Blanchet s.n. 1741 (holótipo-BM, isótipo-G!) syn. nov.

Terrestre, ocasionalmente rupícola; caule decumbente; entrenós 0,4-1,1 cm compr.; catafilos e profilos rosados, avermelhados, ferrugíneos a acastanhados em material vivo e acastanhados a cor-de-palha em material seco, geralmente inteiros e persistentes a caducos e levemente decompostos a decompostos do ápice para a base do caule, cobrindo completamente o caule, 1-6,7 cm compr.; bainha $0,7-2,1 \mathrm{~cm}$ compr.; pecíolo esverdeado, levemente achatado a canaliculado, margens agudas, subagudas a raramente obtusas adaxialmente, obtuso abaxialmente, 7,3-63,3 × 0,2-0,4 cm; genículo fortemente intumescido, escurecido quando senescente, 0,8-3,5 cm compr.; lâmina foliar esverdeada, discolor, ereta a subereta, cartácea em material vivo e seco, não pruinosa abaxialmente, pontos glandulares ausentes, lanceolada, oblonga a subovada, ápice agudo, agudo-apiculado a agudo-acuminado, base subaguda, arredondada, truncada a emarginada, curtamente estreitado-cuneada na parte mais inferior, 16,95-38,9 × 4,9-17,1 cm; nervura basal ausente; nervura mediana obtusa em ambas as faces; nervuras secundárias fortemente impressas adaxialmente e proeminentes abaxialmente, dando o aspecto levemente bulado na face laminar entre as nervuras, 4-14 pares; nervuras coletoras saindo da base laminar ou raramente um pouco acima dela, 0,3-1,95 cm afastadas da margem; pedúnculo esverdeado, às vezes rosado na base e esverdeado para o ápice, 11,9-51,85 cm compr.; espata esverdeada, esverdeadorosada, tornando-se amarronzada, largamente lanceolada, formando ângulo agudo com o pedúnculo, 4,45-10 ×0,8-2,2 cm, decorrência 0,9-1,9 cm compr.; espádice séssil ou estipitado, avermelhado, esverdeado, acastanhado-avermelhado a acastanhado, cilíndrico, 4,1-13,2 cm compr., estípite 0,35$1,1 \mathrm{~cm}$ compr.; flores grandes, com tépalas esverdeadas a cáqui no fruto, pólen amarelado; bagas esverdeadas quando maduras, sendo mais escuras apicalmente com pontos brancos pequenos, oblongas.

Material selecionado: BRASIL. BAHIA: Cachoeira, 13.XII.1992, fl., M. Nadruz et al. 853 (RB). Feira de Santana, 23.III.1984, fl. e fr., R.L. Noblick 3104 (HUEFS). Ilhéus, 30.V.1991, fr., S. Mayo et al. 880 (CEPEC, RB). Itacaré, 25.IV.1991, S. Mayo et al. 773 (CEPEC, RB). Jussari, 8.XI.1998, fl., A. Amorim et al. 2597 (CEPEC). Porto Seguro, 20.VI.1962, fl., A.P. Duarte 6835 (RB); 22.VI.1978, fl., R. Storr 11 (RB). SERGIPE: Santa Luzia do Itanhi, 29.XI.1993, fl., S.C. Sant'Ana et al. 477 (RB).

Possui hábito geralmente terrestre, esciófila a semiesciófila, ocorrendo em restinga e mata submontana até 120 m de altitude. Distribui-se na faixa de vegetação atlântica costeira, sendo quase restrita ao estado da Bahia, com uma única coleta conhecida até o momento para Sergipe. O "Catalog of vascular plant species of eastern Brazil (NYBG 2003)” acrescenta os municípios de Maraú e Una, no estado da Bahia, como áreas de ocorrência de A. bellum. Floresce nos meses de março, junho a dezembro, frutificando nos meses de março e maio.

Espécie caracterizada pelo caule decumbente, extremidade basal da lâmina foliar curtamente estreitada, presença de flores robustas ao longo da espádice, em relação às demais espécies da subseção Flavescentiviridia, e estípite evidente.

Anthurium blanchetianum foi descrita porEngler(1905), sendo corretamente posicionada na subseção Flavescentiviridia. Ao verificar as características de $A$. blanchetianum, tais como: pecíolo sulcado adaxialmente, lâmina foliar ovado-oblonga com a extremidade da base curtamente cuneada e espádice estipitado, além de ocorrência no estado da Bahia, concluise que este táxon é um sinônimo de A. bellum. O próprio Engler, antes mesmo da publicação de $A$. blanchetianum, havia identificado o material tipo (isótipo) depositado no "Conservatoire botanique de Genève" (Blanchet 1741) como A. bellum. Consultandose os ícones de Schott 593-595 relacionados a A. blanchetianum, deduz-se, também, ser esta a mesma que $A$. bellum, em relação aos caracteres acima mencionados, mas principalmente no 
que se refere ao número de flores na espiral principal do espádice: 2-3.

O nome Anthurium bahiense foi publicado sem uma descrição ou qualquer referência, portanto, não é validamente publicado, além disso foi publicado por Engler já como sinônimo de $A$. bellum. Um espécime existe em $\mathrm{K}$, datado de 26 de maio de 1876, por N.E. Brown de uma planta cultivada, originalmente coletada por E.C. Reed na Bahia, na qual Brown escreveu "Anthurium”, adiconando em lápis "bahiense N.E. Brown”. Assim, parece que Engler viu esse espécime ou, mais provavelmente, uma planta viva enviada de Kew, que Brown pensou ser uma nova espécie.

A publicação de Schott da descrição original cita "Brasília, (R. de J.) Pr. Vidensis, Riedel”, indicando que o síntipo de Maximilian de Wied-Neuwied se originou do Rio de Janeiro. Esta localidade parece duvidosa nas evidências apresentadas, desde que Anthurium bellum é conhecida apenas do litoral da Bahia, onde também Maximilian coletou. Ilustração de Schott (Schott Icone Aroid. no. 565) em Viena, tem os dados "Herb. Sonder Colete Neovid”, que não resolve o problema da localidade. Ainda não foi realizada uma busca na coleção do herbário BR, onde a coleção de Wied-Neuwied está depositada. A coleção síntipo de Riedel está representada em Viena por duas ilustrações de Schott, Icone. n. 567A com os seguintes dados: "In arenosis pr. Castelnovo No. 567. Dezembro 1821. Brasil. Riedel”, e no. 567B com os dados "Pothos fol. cordato-in prope arenosis. Castelnovo $\times$ br. 1821 Riedel. Herb. Hort. Petropol”.

No Prodromus Systematic Aroideae (1860), Schott alterou a citação em relação a obra princeps: - "Brasília, Rio janeiro? Riedel. - v. specimen sicca spont. In Herb. Hort. Petrop etc.” Ele omite a menção ao material de WiedNeuwied e concentra-se, em vez disso, na coleção de Riedel (coletado na natureza) que foi depositado em LE, que menciona ter visto. Embora não se tenha certeza do local correto, se for assumido que a coleção citada é a mesma representada pelos dois Icones Schott 567A e B, então o problema da localidade está resolvido: P.L.K. Urbano (Flora brasiliensis I (1): p. 90. 1906) afirma que em 1821 Riedel visitou Castelnovo no litoral da Bahia, uma localidade perto da atual cidade de Ilhéus.

Coletas posteriores feitas por Maly, na expedição de Archduke Ferdinand Maximilian, estão representadas em $\mathrm{W}$ por quatro ilustrações na coleção dos Icones Aroideae de Schott: n. 566 é um desenho a lápis com o dado "E.F.M. Itaparica” (EFM = Erzherhog Ferdinand Maximilian). Os Icones números 3485, 3486 e 3487 são pinturas e dados são escassos, mas são quase certamente da mesma coleção, cultivados nos Jardins do Palácio de Schoenbrunn, e formam a base da ilustração publicada por Peyritsch (Aroideae Maximilianae 1879).

Pelo fato do material coletado por Riedel ter se perdido, não existindo mais no herbário LE, escolheu-se o Icone Aroideae de Schott número 567A que apresenta as características principais da espécie e, certamente, é uma ilustração do material original, conforme exposto acima.

Anthurium bellum está sendo transferida da subseção Obscureviridia para Flavescentiviridia, por apresentar principalmente lâmina foliar discolor, membranácea a cartácea, nervuras secundárias impressas adaxialmente e proeminentes abaxialmente, sendo mais salientes que as terciárias e espata lanceolada.

3. Anthurium bocainense Catharino \& Nadruz, Rodriguesia 56(88): 36-38. 2005. Tipo: BRASIL, SÃO PAULO, São José do Barreiro, Serra da Bocaina, Parque Nacional da Bocaina. 20.VII.1994, L. Rossi \& E.L.M. Catharino 1603 (holótipo - SP!, isótipo - RB!).

Fig. 1d-e

Terrestre ou epífita; caule ereto; entrenós 0,4-1 cm compr.; catafilos e profilos inteiros a decompostos no ápice, decompostos e caducos para a base do caule, 1,9-3,2 cm compr.; bainha vinácea em pecíolo jovem, tornando-se esverdeada com margens amarelo-vináceas a cor de palha, 2-2,7 cm compr.; pecíolo esverdeado, obtuso abaxialmente, achatado a levemente sulcado com margens 
obtusas adaxialmente, 20,2-52 cm compr.; genículo esverdeado-amarelado e mais espesso que o pecíolo, levemente sulcado adaxialmente, $0,5-3 \mathrm{~cm}$ compr.; lâmina esverdeada levemente discolor, levemente pruinosa abaxialmente, cartácea em material vivo, membranácea em material seco, perpendicular, pontos glandulares ausentes, raramente semipeltada, estreitamente ovada, base cordada, lobos arredondados e seio triangular, ápice rostrado, curtamente apiculado, 14,3-33 ×3,7-14,5 cm; nervura mediana obtusa abaxialmente, aguda adaxialmente; nervuras basais 3 em ambas as faces, fortemente impressas adaxialmente, a mais externa unindo-se a margem ainda no lobo posterior, a mediana juntando-se a margem no terço inferior e a mais interna unindo-se no terço superior; nervuras secundárias 4-10 em ambas as faces, tênues sendo visíveis do meio para o ápice; nervura coletora saindo em ângulo agudo em relação a nervura mediana, tornando-se elíptica até o ápice da lâmina, 0,7-2,4 cm afastada da margem na região mediana, unindo-se à margem a cerca de 1,5 cm do ápice; pedúnculo vináceoacastanhado, esverdeado no ápice, cilíndrico, 14-50 cm compr.; espata esverdeada a esverdeado-vinácea com as margens levemente acastanhadas a vinácea, membranácea, linearlanceolada, navicular, perpendicular e formando ângulo agudo em relação ao pedúnculo, , 2,5-7,2 ×0,5-1,1cm, decorrência 2 mm compr.; espádice estipitado, acastanhado, cilíndrico, 2,5-8,8 × 0,3 cm, estípite vináceo, $1-3,5 \mathrm{~cm}$ compr.; bagas imaturas esverdeadas. Material examinado: BRASIL. SÃO PAULO: Bananal, Serra da Bocaina, 22.VI.2006, fl., M. Nadruz et al. 1685 (RB); 22.VI.2006, fl., M. Nadruz et al. 1689 (RB).

Espécie terrestre, ocorrendo em florestas baixas de altitude, sobre a serrapilheira em locais úmidos e ensolarados. Tem ocorrência registrada apenas para o município de Bananal, nordeste do estado de São Paulo, dentro e no entorno do Parque Nacional da Bocaina, provavelmente também no município de São José do Barreiro e outros limítrofes. É necessário um estudo complementar de coletas e acompanhamento de material cultivado para observação completa do fruto maduro. O material cultivado se desenvolve com as mesmas características daquele encontrado na natureza. Tendo sido encontrado florescendo nos meses de março e julho.

Anthurium bocainense pode ser confundida com A. Ihotzkyanum Schott, diferindo desta por apresentar lâmina foliar levemente pruinosa abaxialmente, estreitamente ovada, três nervuras basais fortemente impressas na face adaxial, espata navicular, formando ângulo agudo com o pedúnculo e espádice com estípite maior que $1 \mathrm{~cm}$ compr.

Coelho \& Catharino (2005) descrevem o epíteto específico erroneamente (A. bocainensis), sendo corrigido neste trabalho (A. bocainense).

Até o momento $A$. bocainense encontra-se Criticamente em Perigo (CR), por ocorrer em uma área estimada menor que $100 \mathrm{~km}^{2}$, conhecida somente de uma única localidade e tamanho populacional reduzido com populações estimadas em menos de 250 indivíduos (IUCN 1998).

4. Anthurium boudetii Nadruz, Aroideana 29: 91. 2006. Tipo: BRASIL. ESPÍRITO SANTO: Vargem Alta, 28.VIII.1985, fl., H. B. Fernandes 1451 (holótipo - MBML!). $\quad$ Fig. 1f

Terrestre; caule ereto; entrenós 1,1-1,9 cm compr.; catafilos e profilos acastanhados a cor-de-palha em material seco, acastanhado, inteiros a levemente decompostos no ápice, inteiros a levemente decompostos e persistentes para a base do caule, $1,1-4,1 \times 2,1 \mathrm{~cm}$; bainha 0,7-1,7 cm compr.; pecíolo ereto, obtuso abaxialmente, sulcado com margens obtusas adaxialmente, 9,5-14,1 $\times 0,18-0,24 \mathrm{~cm}$; genículo 0,7-1 cm compr.; lâmina foliar esverdeada discolor, cartácea em material seco, ereta, não pruinosa abaxialmente, pontos glandulares ausentes, lanceolada, igualmente estreitada para ambas as extremidades, ápice rostrado, base aguda, 23,5-27,3 × 4,2-5,5 cm; nervura mediana arredondada abaxialmente, aguda adaxialmente; nervuras secundárias levemente impressas a pouco visíveis adaxialmente, levemente visíveis a obscuras abaxialmente, cerca 
de 10-11 pares; nervuras coletoras saindo da base laminar ou um pouco acima dela, 5-7 mm afastadas da margem; pedúnculo 4,6-25 $\times$ $0,07 \mathrm{~cm}$; espata esverdeada, lanceolada, deflexa na antese, 1,6 $\times 0,5 \mathrm{~cm}$, formando ângulo reto com o pedúnculo; espádice vináceo, cilíndrico, curtamente estipitado, $1,8 \times 0,38 \mathrm{~cm}$, estípite 1 mm compr.; bagas não observadas.

Material selecionado: BRASIL. ESPÍRITO SANTO: Ibiraçu, 28.V.1990, fl., H.B. Fernandes et al. 2962 (MBML, RB). Marataizes, 4.XII.1972, fl., P.L. Krieger et al. 11927 (CESJ, RB). São Mateus, 2.VIII.1969, fl., D. Sucre 5475 (RB). Santa Teresa, 28.VIII.1985, fl., H.B. Fernandes 1344 (MBML).

Anthurium boudetii é endêmica do Espírito Santo e possui o hábito terrestre, podendo ser encontrada em vegetação de restinga, vegetação de tabuleiro, chegando a floresta de encosta atlântica montana e alto-montana, em locais sombreados e semi-heliófilos.

É muito semelhante a A. intermedium, sendo que esta possui catafilos e profilos levemente decompostos a decompostos no ápice e raramente inteiros a decompostos, raramente persistentes a caducos para base do caule, contra catafilos e profilos inteiros a levemente decompostos no ápice e para a base do caule, persistentes em $A$. boudetii. Pode ser distinguida pelo seu hábito terrestre, o porte ereto das folhas, a persistência dos catafilos e profilos geralmente inteiros (não decompostos) e entrenós visíveis (não cobertos) entre os catafilos ao longo do caule. É necessário um estudo do material vivo para a observação dos demais caracteres, tais como: forma do pecíolo, da nervura mediana, do pedúnculo, cor do fruto, e consequentemente complementar a diagnose da espécie.

Floresce em maio, agosto e novembro, porém sem registro de frutificação, sendo recomendável coletas periódicas para confirmar períodos de floração e frutificação.

5. Anthurium bragae Nadruz, Aroideana 29: 91. 2006. Tipo: BRASIL. RIO DE JANEIRO: Itatiaia, trilha do hotel Simon para os Três Picos, 1100 m, 15.V.1999, J.M. Braga \& A. Quinet 5182 (holótipo - RB!).

Fig. 1g-h

Terrestre; caule ereto; entrenós $0,4-2,8 \mathrm{~cm}$ compr.; catafilos e profilos esverdeado- esbranquiçados com carenas levemente rosadas, esverdeado-avermelhados a acastanhados, inteiros, levemente decompostos a decompostos no ápice, acastanhados, persistentes a caducos, inteiros, levemente decompostos a decompostos para a base do caule, 1,1-5 cm compr.; bainha 0,9-3 cm compr.; pecíolo jovem esverdeado, salpicado de pequenos pontos rosados a esverdeado-avermelhado, obtuso abaxialmente sendo sulcado com margens obtusas adaxialmente, 6,6-16,3 cm compr.; genículo mais espesso, esverdeado a rosado em folha jovem, avermelhado, vináceo a esverdeado mais escuro na folha adulta, em relação ao pecíolo, 0,8-1,8 cm compr.; lâmina foliar esverdeada fortemente discolor, cartácea a fortemente cartácea em material vivo e subcartácea a membranácea em material seco, ereta, não pruinosa abaxialmente, pontos glandulares ausentes, elíptica a subobovada, base geralmente aguda, obtusa a truncada, ápice obtuso-acuminado, apiculado, rostrado, igualmente estreitada para ambas as extremidades, $13,1-28,7 \times 6-9,7 \mathrm{~cm}$; nervura mediana obtusa em ambas as faces a aguda adaxialmente; nervuras secundárias impressas a fortemente impressas adaxialmente, proeminentes abaxialmente, $5-11$ em ambas as faces; nervuras coletoras saindo da base da lâmina ou um pouco acima dela, 0,4-1,4 cm afastadas da margem; pedúnculo esverdeado a avermelhado no terço inferior e esverdeado a acastanhado no terço superior, levemente 1carenado, 4,3-10,5 cm compr.; espata esverdeada a esverdeado-vinácea quando nova, tornandose esverdeada a acastanhada quando adulta, persistente, navicular, lanceolada, 2-4,1×0,7$1 \mathrm{~cm}$, formando ângulo agudo com o pedúnculo, decorrência 3-6 mm compr.; espádice esverdeado a cor-de-palha, 3,2-7,5 cm compr., estipitada, estípite subséssil, $2-5 \mathrm{~mm}$ compr.; bagas imaturas esverdeadas.

Material selecionado: BRASIL. RIO DE JANEIRO: Itatiaia, 6.II.2002 fl., M. Nadruz et al. 1455 (RB).

Espécie semelhante a $A$. parvum diferenciando-se por apresentar entrenós acima de 0,4 cm compr., nervuras secundárias 5-11 impressas adaxialmente e proeminentes abaxialmente, pedúnculo menor que 11 cm compr. 
com carena, espata formando ângulo agudo com o pedúnculo, espádice esverdeado a cor da palha. Anthurium bragae é reconhecido pelas folhas eretas de lâminas com formas subovadas a ovado-lanceoladas, com as nervuras bem visíveis em ambas as faces e pela presença de um curto estípite. É necessário um estudo complementar de coletas e/ou acompanhamento de material cultivado para observação completa do fruto maduro. O material cultivado se desenvolve com as mesmas características daquele encontrado na natureza.

Anthurium bragae é uma espécie terrestre de floresta de encosta atlântica altomontana, ocorrendo acima dos $1.000 \mathrm{~m}$ de altitude, em locais sombreados e úmidos. Até o momento tem sua ocorrência restrita ao Parque Nacional de Itatiaia no estado do Rio de Janeiro, sendo que deve estender-se para municípios adjacentes que dão continuidade a Serra da Mantiqueira.

Floresce e frutifica nos meses de fevereiro, sendo recomendável coletas periódicas para confirmar período maior de floração e frutificação.

Segundo critéros da IUCN (1998) A. bragae encontra-se Vulnerável (VU), por possuir uma extensão de presença estimada menor que 20.000 km², porém a área do Parque Nacional de Itatiaia sofre grande influência antrópica juntamente com constantes incêndios.

6. Anthurium comtum Schott, Bonplandia 10: 87. 1862. Tipo: Desenho colorido de uma planta cultivada nos Jardins Imperiais, Palácio de Schönbrunn, Vienna, Austria. Icone Schott no. 3491 (neótipo - W!, designado por Coelho, 2007). BRASIL. SÃO PAULO: São José do Barreiro, Parque Nacional da Bocaina, mata atlântica de encosta, $1120 \mathrm{~m}, 2^{\circ} 49^{\prime} 04^{\prime \prime}$ S 443'30'”'W, 28.VI.2001, M. Nadruz \& J.B. Silva 1418 (epitipo - RB!, designado por Coelho, 2007).

Fig. 1i, 2a-b

Epífita, raramente terrestre, rupícola ou saxícola; caule ereto; entrenós $2-6 \mathrm{~mm}$ compr.; catafilos e profilos cremes com ápice rosados a rosados quando novos, creme-rosados, esverdeados, esverdeados com margens vináceas, esverdeado-amarelados, acastanhados e corde-palha, inteiros, levemente decompostos a decompostos no ápice, tornando-se acastanhados, cor-de-palha, decompostos a caducos para a base do caule, 1-7,1 cm compr.; bainha 0,8-9 cm compr.; pecíolo esverdeado, acastanhado a castanho-rosado, cilíndrico a raramente agudo abaxialmente, achatado, subcanaliculado, canaliculado a sulcado com margens agudas a freqüentemente carenadas adaxialmente, 1,6$27 \mathrm{~cm}$ compr.; genículo mais espesso e raramente concolor, mais escuro a mais claro que o pecíolo, 0,3-2,9 cm compr., achatado a carenado adaxialmente; lâmina foliar esverdeada fortemente discolor sendo esverderdeado-amarelada abaxialmente, ereta a subereta, não pruinosa abaxialmente, pontos glandulares ausentes, cartácea em material vivo e levemente cartácea a membranácea em material seco, linear-lanceolada a lanceolada, raramente oblongo-lanceolada, freqüentemente levemente mais estreitada para a base, igualmente estreitamente para ambas extremidades a raramente mais estreitada em direção ao ápice, base raramente cuneada, aguda a subtruncada, freqüentemente obtusa, ápice agudo, agudo-acuminado, rostrado, 15,9$63,2 \times 2-12 \mathrm{~cm}$; nervura mediana obtusa a aguda no comprimento total, obtusa, subaguda a levemente achatada da metade para a base, aguda a obtusa próximo ao ápice adaxialmente, obtusa a raramente aguda abaxialmente a obtusa em ambas as faces; nervuras secundárias impressas a levemente impressas adaxialmente, proeminentes a levemente proeminentes abaxialmente, 7-25 em ambas as faces; nervuras coletoras saindo da base da lâmina ou um pouco acima dela, 2-9,5 $\mathrm{mm}$ afastadas da margem; pedúnculo amarelado quando envelhecido, esverdeado, vináceo, verdevináceo, cilíndrico, raro levemente achatado, raramente formando sulcos ao longo, subcarenado a raramente 2-3 carenado, 7,457 cm compr.; espata membranácea, persistente em inflorescência nova, deflexa, linearlanceolada, lanceolada, vinácea nas margens e na base, esverdeado-vinácea na metade inferior a vinácea na metade superior, esverdeada com o ápice esverdeado-amarelado, esverdeada com margem acastanhada, esverdeada, podendo 

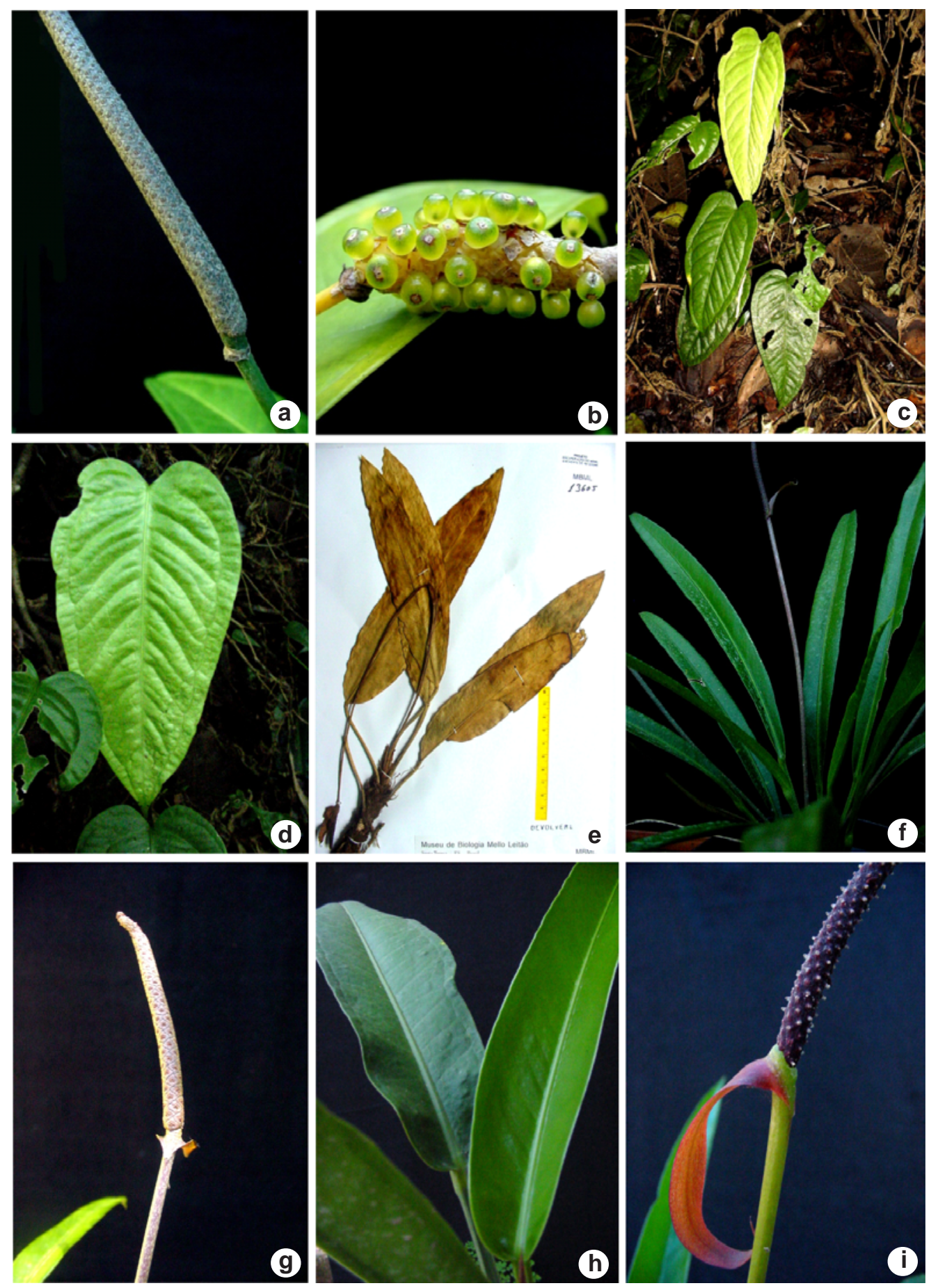

Figura 2 - a-b. Anthurium comtum - a. detalhe da inflorescência sem espata (Nadruz 1418 cultivado no JBRJ); b. detalhe da infrutescência (Nadruz 1354 cultivado no JBRJ). c-d. A. fontellanus - c. hábito; d. lâmina foliar (Nadruz 1678). e. A. fragae - e. hábito (Kollmann 3233). f-g. A. gomesianum - f. hábito; g. detalhe do espádice (Fraga 644 cultivado no JBRJ). h-i. A. harrisii - h. detalhe da folha; i. detalhe da inflorescência (Nadruz 1358 cultivado no JBRJ).

Figura 2 - a-b. Anthurium comtum - a. detail of the inflorescence without the spathe (Nadruz 1418 cultivated at the JBRJ); b. detail of the infrutescence (Nadruz 1354 cultivated at the JBRJ). c-d. A. fontellanus - c. habit; d. leaf blade (Nadruz 1678). e. A. fragae - e. habit (Kollmann 3233). f-g. A. gomesianum - f. habit; g. detail of the spadix (Fraga 644 cultivated at the JBRJ). h-i. A. harrisii - h. detail of the leaf; i. detail of the inflorescence (Nadruz 1358 cultivated at the JBRJ). 
apresentar linha vinácea ao longo do comprimento, posteriormente cor-de-palha, acastanhada, amarronzada, freqüentemente caduca, 3-12,5×0,5-1,2 cm, formando ângulo agudo a obtuso com o pedúnculo, decorrência 0,1-1,1 cm compr.; espádice esverdeada, arroxeada, vinácea, púrpuro-amarronzada, acastanhada quando jovem, tornando-se corde-palha (marrom-acinzentada, amarronzada, marrom-amarelada, amarelada, pardacenta, acastanhada), 2,9-20,1 cm compr., séssil a estipitado, estípite 1-6 mm compr.; bagas imaturas esverdeadas, maduras com ápice esverdeado tornando-se amarelados a esbranquiçados para a base, semente amarelada, verrugosa, oblongo-globosa.

Material selecionado: BRASIL. BAHIA: Jussari, 18.IX.2002, fl., P.P. Fiaschi et al. 1069 (CEPEC). Porto Seguro, fl., W. Thomas et al. 11315 (CEPEC). Santa Cruz Cabralia, 11.I.1977, fl., R. Harley et al. 17841 (CEPEC); 24.VIII.1994, M.L. Guedes et al. 3458 (ALCB). ESPÍRITO SANTO: Linhares, 19.VII.1976, J.A.R. Bittencourt s.n. (MBML 1370). Santa Teresa, 18.IX.2002, fl. e fr., M. Nadruz et al. 1520 (RB). MINAS GERAIS: Descoberto, 31.X.2001, fl. e fr., V.R. Almeida et al. 15 (CESJ). Faria Lemos, 21.VI.2002, M. Nadruz et al. 1482 (RB). Rio Novo, IX.1894, fl., C.A.W. Schwacke 11122 (RB). Santa Rita de Jacutinga, 27.VII.1970, fl., P.L.K. Urbano et al. 9002 (RB). Viçosa, 1935, fl., JEJS 2 (RB). PARANÁ: Antonina, 29.XI.1973, fl., G. Hatschbach 33404 (RB). Cerro Azul, 18.VII.1984, fl., G. Hatschbach 48102 (MBM). Morretes, 13.II.2000, fl. e fr., C. Kozera et al. 1389 (UPCB). RIO DE JANEIRO: Angra dos Reis, 7.VIII.1992, fl., D.S. Pedrosa 1413 (GUA). Itatiaia, 5.II.2002, M. Nadruz et al. 1453 (RB). Magé, fl., T. Fontoura et al. 219 (RB). Mangaratiba, 22.II.2003, fl., J.M. Braga 7178 (RB). Mendes, 10.IX.1993, fl., T. Konno 275 (RUSU). Nova Friburgo, 13.VIII.1993, fl., C.M. Vieira et al. 348 (RB). Nova Iguaçu, 3.X.2001, fr., M. Nadruz et al. 1441 (RB); 20.VI.1995, fl. e fr., S.J.S. Neto 642 (RB). Parati, 24.XI.1994, fr., M. Bovini et al. 632 (RB); 22.VIII.1995, fl., M. Bovini et al. 866 (RB). Petrópolis, 25.VIII.1983, fl., R. Guedes et al. 367 (RB). Rio de Janeiro, 5.IV.2001, fl. e fr., M. Nadruz et al.1359 (RB). Santa Maria Madalena, 13.XI.1999, fr., Pinto et al. 313 (RB, FFP). SÃO PAULO: Bananal, 11.IX.2001, fl., P.R.L. Morais et al. 101 (BHCB). Campos do Jordão, XII.1945, fl., J.E. Leite 3560 (GH). Eldorado, 4.IX.1995, fl., V.C. Souza et al. 9146 (ESA). Iguape, 10.I.1999, fl., E.R. Batista et al. 107 (ESA).
Ilha Bela, VI.1991, fl., V.C. Souza et al. 2556 (ESA). São José do Barreiro, 28.VI.2001, fl., M. Nadruz 1418 et al. (RB).

Espécie geralmente epifítica, podendo ser encontrada esporadicamente como terrestre, rupícola ou saxícola, em ambientes sombreados, semi-heliófilos e úmidos, em matas de tabuleiro até montana, chegando a 1.200 m altitude. Possui a maior distribuição entre as espécies da subseção Flavescentiviridia, das matas sulbaianas, passando pelos estados do Sudeste, chegando até o Paraná. Floresce o ano todo e frutifica nos meses de fevereiro, abril a novembro.

É facilmente identificada pelo hábito epifítico, pela forte discoloração da lâmina foliar, pelas nervuras secundárias bem evidentes em ambas as faces da lâmina, pela espata geralmente efêmera e pela coloração de palha da espádice.

7. Anthurium fontellanus Nadruz \& Leoni, Pabstia 15(2): 2-4. 2004. Tipo: BRASIL. MINAS GERAIS: Serra do Boné, Parque Estadual da Serra do Brigadeiro, floresta pluvial tropical, $20^{\circ}$ 41'S, 42 26' 'W, 1.IV.1994, L.S. Leoni 2500 (holótipo - GFJP!, isótipo - RB!). Fig. 2c-d

Terrestre; caule ereto, alongado; entrenós $0,8-1,5$ cm compr.; catafilo e profilo esverdeados, rosados a avermelhados e inteiros no ápice, cor de palha a acastanhados, inteiros a levemente decompostos e persistentes a caducos para a base do caule, 1,9-4 cm compr.; bainha 1,2-1,9 cm compr.; pecíolo esverdeado a esverdeado levemente rosado, cilíndrico, levemente sulcado com margens obtusas adaxialmente, obtuso abaxialmente, 14,4-17,2×0,12-0,24 cm; genículo levemente mais espesso, esverdeado-rosado a concolor com o pecíolo, 1-1,6 cm compr.; lâmina foliar esverdeada, levemente discolor, perpendicular em relação ao pecíolo, membranácea, ovada, ápice obtuso-acuminado, base truncada a subcordada, seio subespatulado a triangular, lobos posteriores arredondados, não pruinosa abaxialmente, sem a presença de pontos glandulares, 11,9-12,1 ×7,1-7,2 cm; nervura mediana aguda em ambas as faces; nervuras secundárias fortemente impressas adaxialmente, 
dando uma forma bulada a lâmina foliar, fortemente proeminente abaxialmente, 4-7; nervura coletora saindo da base laminar, 6$7 \mathrm{~mm}$ afastada da margem; nervura basal 1 , terminando na base dos lobos posteriores; pedúnculo esverdeado, avermelhado a vináceo quando envelhecido, subachatado, 4,6-14 × 0,1-0,18 cm; espata aplanada, membranácea, formando ângulo subagudo a agudo com o pedúnculo, 3-3,6 × $6 \mathrm{~mm}$; espádice estipitado, acastanhado quando envelhecido, cilíndrico, 3-4,5 cm, estípite 0,9$1,5 \mathrm{~cm}$ compr.; frutos imaturos esverdeados. Material selecionado: BRASIL. MINAS GERAIS: Araponga, 1.IV.1994, L.S. Leoni 2500 (GFJP); 23.VI.2004, fl., M. Nadruz 1574 et al. (-parátipo RB!). SÃO PAULO: Bananal, 20.VI.2006, fl., $M$. Nadruz 1678 et al. (RB).

Espécie terrestre, com ocorrência acima de $1.300 \mathrm{~m}$ de altitude, em floresta estacional semidecidual de encosta altomontana e floresta ombrófila densa alto-montana, em áreas de transição para campos de altitudes, em locais úmidos e sombreados. Anthurium fontellanus tem ocorrência registrada para o Parque Estadual da Serra do Brigadeiro situado a leste do estado de Minas Gerais, um prolongamento da Serra da Mantiqueira, e para a Serra da Bocaina, Bananal, São Paulo. Floresce e frutifica em junho.

Espécie muito próxima de $A$. unense, diferindo por possuir entrenó maior que $0,8 \mathrm{~cm}$ compr., lâmina foliar semi-ereta a perpendicular, menor que $13 \times 7 \mathrm{~cm}$, nervuras secundárias 4-7 e espata aplanada.

Anthurium fontellanus é caracterizada principalmente pela lâmina foliar bulada, onde as nervuras secundárias e basais são fortemente impressas na face adaxial e pela presença de estípite longo. Coelho \& Leoni (2004) citam a presença de um caráter semelhante a pêlos nas tépalas, característica essa nunca antes vista no gênero. Foram realizadas algumas seções transversais nas tépalas para observações mais apuradas, ficando descartado a possibilidade da presença de fungos. Estudos mais detalhados são necessários para a confirmação desse caráter.
Segundo a lista vermelha das espécies ameaçadas, Anthurium fontellanus, até o momento é considerada em Em Perigo (EN), por apresentar área de ocupação menor que $500 \mathrm{~km}^{2}$, distribuição geográfica fragmentada em não mais que cinco localidades com diminuição contínua em número de indivíduos adultos e tamanho populacional com número de indivíduos maduros menor que 250 .

8. Anthurium fragae Nadruz, Aroideana 29: 96. 2006. Tipo: BRASIL. ESPÍRITO SANTO: Castelo, Forno Grande, 1400 m, 13.X.2000, fl., L. Kollmann \& C.N. Fraga 3233 (holótipo MBML!).

Fig. 2e

Rupícola; caule ereto; entrenós 1,5-2 mm compr.; catafilos e profilos acastanhados em material seco, inteiros, levemente decompostos a decompostos no ápice, levemente decompostos a decompostos e caducos para a base do caule, 1,5-6,8 cm compr.; bainha1,2 cm compr.; pecíolo canaliculado a sulcado adaxialmente, com margens agudas (?), obtuso abaxialmente (?), 6,2-13 cm compr.; genículo 2-7 mm compr.; lâmina foliar esverdeadaverde, ereta, membranácea a levemente cartácea em material seco, não pruinosa abaxialmente, pontos glandulares ausentes, lanceolada a subovada, mais estreitada em direção ao ápice, base aguda, subaguda, obtusa a raramente subcordada, ápice agudo a curtamente apiculado, $11-33,5 \times 2,8-9,2 \mathrm{~cm}$; nervura mediana obtusa adaxialmente (?) e não observada abaxialmente; nervuras secundárias pouco visíveis em ambas as faces, 9-16 em ambas as faces; nervuras coletoras saindo da base laminar ou raramente acima dela, 0,3$1,1 \mathrm{~cm}$ afastadas da margem; pedúnculo 23,7-43,6 cm compr.; espata subcartácea, lanceolada, cuspidada, vinácea, 2,8-7,1×0,7$1,8 \mathrm{~cm}$, triangular-lanceolada formando ângulo agudo com o pedúnculo; espádice vináceo a acastanhado, cilíndrico, 2,3-6,7 cm compr., séssil; bagas não observadas.

Material selecionado: BRASIL. ESPÍRITO SANTO: Castelo, 12.VII.2005, fl., L.Kollmann et al. 7981 (MBML). 
Espécie rupícola e heliófila, raramente esciófila, endêmica do município de Castelo no Espírito Santo, ocorrendo em altitudes acima de $1.500 \mathrm{~m}$ altitude, em matas montanas de encosta. Floresce em janeiro, julho e outubro. São necessárias coletas intensivas nas áreas vizinhas para o estabelecimento correto da delimitação geográfica, floração e frutificação de A. fragae.

Muito semelhante a $A$. organense, diferindo desta pelo hábito heliófilo, pedúnculo maior que $30 \mathrm{~cm}$ compr., espádice séssil, contra hábito esciófilo, pedúnculo menor que $30 \mathrm{~cm}$ compr. e espádice estipitado. Pode ser reconhecida pelo seu porte ereto e pelas lâminas foliares cartáceas, lanceoladas estreitando-se igualmente para ambas as extremidades, com ápice e base agudos.

Anthurium fragae encontra-se Criticamente em Perigo (CR), segundo os critérios da IUCN (1998), por ocorrer numa área estimada menor que $100 \mathrm{~km}^{2}$ e conhecida somente de uma única localidade.

9. Anthurium gomesianum Nadruz, Aroideana 29: 98. 2006. Tipo: BRASIL. ESPÍRITO SANTO: Santa Tereza, São João de Petrópolis, Barracão, Escola Agrotécnica Federal de Santa Teresa, ca. 250 m., 15.VII.2000, C.N. Fraga, V. Demuner et al. 644 (holótipo - RB!).

Fig. 2f-g

Rupícola ou terrestre; caule ereto; entrenós curtíssimos; catafilos e profilos esverdeados e inteiros quando novos, tornandose acastanhados, levemente decompostos, decompostos a raramente inteiros no ápice, decompostos a caducos para a base do caule, 0,95-5,4 × 1,2 cm; bainha 5-9,5 mm compr.; pecíolo esverdeado, levemente canaliculado com margens subagudas adaxialmente, obtuso abaxialmente, $2,1-18,9 \times 0,19-0,3 \mathrm{~cm}$; genículo levemente mais claro que o pecíolo, 2-9 mm compr.; lâmina esverdeada discolor, semi-ereta, cartácea, não pruinosa abaxialmente, pontos glandulares ausentes, linear-lanceolada, igualmente estreitada para ambas extremidades, base aguda a curtamente cuneada, ápice subrostrado a rostrado- apiculado, 19-37,3 × 1,3-3,9 cm; nervura mediana subaguda a aguda adaxialmente e obtusa abaxialmente; nervuras secundárias obscuras adaxialmente e tênues abaxialmente, 13-20; nervura coletora saindo da base laminar ou acima dela, 0,5-5 mm afastada da margem, raramente estendendo-se até a margem; pedúnculo ereto, em pré-antese vináceo, tornando-se vináceo-esverdeado, cilíndrico a levemente anguloso, rígido, 12,5$40,3 \times 0,2-0,26 \mathrm{~cm}$; espata membranácea, aplanada, persistente, vináceo-esverdeada, avermelhada, lanceolada, subereta em início de antese, perpendicular a subreflexa em antese, formando ângulo agudo com o pedúnculo, 0,3-1 cm decorrência, 1,7-4,2 × 0,2-0,9 cm; espádice vináceo, acastanhado em antese, séssil a curtamente estipitado, cilíndrico, 3,85-11,3 ×0,22-0,46 cm, estípite até $0,3 \mathrm{~cm}$ compr.; bagas esverdeadas.

Material selecionado: BRASIL. ESPÍRITOSANTO: Santa Teresa, 08.X.1985, fl., H.B. Fernandes 1551 (MBML); 3.XI.2001, fl. e fr., A.P. Fontana et al. 221 (MBML). São Roque do Canaã, 20.XII.2003, fl. e fr., A.P. Fontana et al. 646 (MBML).

Espécie frequentemente epífita, raramente rupícola ou terrestre, A. gomesianum tem sua principal distribuição na região central espíritosantense e no vale do Mucuri em Minas Gerais. Ocorre em floresta atlântica sub-montana e montana entre 450-950 m de altitude, em locais úmidos, sombreados, raramente em locais abertos e ensolarados. Certamente com novas coletas nas áreas adjacentes às localidades conhecidas, principalmente ao longo da serra da Mantiqueira, o limite geográfico para a espécie será ampliado.

Anthurium gomesianum é semelhante a A. longifolium, diferindo desta por apresentar porte mais delicado, entrenós mais curtos, catafilos com a metade do comprimento, lâmina foliar com a metade da largura e bagas esverdeadas. A. gomesianum pode ser reconhecida pelas lâminas foliares arcoadas e linear-lanceoladas com a base aguda a cuneada e pelo caule curto. Floresce em fevereiro, abril, junho, julho e de setembro a dezembro, frutificando no mês de dezembro. 
Até o momento A. gomesianum encontrase vulnerável (VU), segundo os critérios da IUCN (1998), por possuir uma população estimada em menos de 1000 indivíduos maduros, muito restrita em números de localidades (duas até o momento). É recomendável a continuidade de coletas na área a fim de que se tenha um aumento do conhecimento das espécies do gênero Anthurium, e uma adequada amostragem de $A$. gomesianum.

10. Anthurium harrisii (Graham) G.Don in R. Sweet, Hort. Brit., ed. 3: 633. 1839. Pothos harrisii Graham in Edinburgh Philos. J. 14: 353. III/IV.1826. Tipo: BRASIL. RIO DE JANEIRO: J. Harris s.n. (holótipo - K!).

Fig. 2h-i, 3a-d

A. consanguineum Kunth ex Schott, Prodr. Syst. Aroid. 456. 1860. Tipo: Desenho a lapis de um espécime de planta cultivada no Jardim Botânico de Berlin em 1840, com anotação " $A$. consanguineum Kunth (Caulescens radicans) Hrb. G. Berol. - cum Harrisii conjuncta Hort. Berol. 1840”. Schott Icone Aroideae No. 375 (W!) (neótipo - W!, designado por Coelho, 2007).

A. undulatum C.Koch \& Bouche in Index Sem. [Berlin] 1854, Appendix: 10. 1855. Tipo: Impressão a lápis feita por N.E. Brown do espécime tipo no herbário de K. Koch (antigamente em B, agora perdido) com anotação: “Anthurium undulatum C. Koch. Impressão do espécimem tipo! no herbário de C. Koch. N.E. Brown Sept. $2^{\text {nd }}$ 1878” (neótipo - K!, designado por Coelho, 2007).

A. assimile Schott ex Schott in Oesterr. bot. Wochenbl. 5: 82. 1855. Tipo: Ilustração colorida de uma planta cultivada nos jardins imperiais, Palácio de Schönbrunn, Austria. Schott Icon Aroideae No. 359 (W!) (neótipo - W!, designado por Coelho, 2007).

A. harrisii var. pulchrum N.E. Br., Gard. Chron. new ser. 14: 358. 1880. Tipo: Planta cultivada na Inglaterra por W. Bull, VIII.1880, introduzida do Brasil, próximo ao Rio de Janeiro, Bull s.n. (holótipo - K!).

Terrestre ou rupícola, raramente hemiepífita; caule ereto; entrenós $0,1-1,7 \mathrm{~cm}$ compr.; catafilos e profilos esverdeados quando novos, esverdeado-rosados, rosados, acastanhado-esverdeados, acastanhados, corde-palha, persistentes, inteiros a decompostos no ápice, cor-de-palha, acastanhados, levemente decompostos a decompostos, persistentes a caducos para a base do caule, $1,5-10,6 \times 1,4-5,4 \mathrm{~cm}$; bainha $0,6-8,2 \mathrm{~cm}$ compr.; pecíolo esverdeado, esverdeadovináceo, avermelhado, vináceo, geralmente obtuso a raramente subagudo a carenado abaxialmente, plano, subcanaliculado a sulcado com margens agudas a carenadas adaxialmente, 1,1-35,75 × 0,4-0,5 cm; genículo concolor, mais claro e mais espesso que o pecíolo, tornando-se cor-de-palha quando envelhecido, 0,3-1,5 cm compr.; lâmina foliar esverdeada raro levemente discolor a discolor, ereta, membranácea a cartácea em material seco, cartácea em material vivo, não pruinosa abaxialmente, pontos glandulares ausentes, linear-lanceolada a lanceolada, estreitando-se igualmente para ambas as extremidades a levemente mais estreitada para a base, ápice agudo, apiculado a rostrado, base frequentemente obtusa, raramente subtruncada, subaguda a aguda, 16-79,9 × 2,1-18,4 cm; nervura mediana geralmente cilíndrica, raramente aguda a carenada tornando-se obtusa próximo ao ápice e subcarenada próximo a base abaxialmente, geralmente aguda tornando-se obtuso-achatada próximo a base na face adaxial a raramente aguda em ambas as faces; nervuras secundárias 823 em ambas as faces, levemente impressas, tênues a obscuras adaxialmente, levemente proeminentes abaxialmente; nervuras coletoras nascendo na base da lâmina 0,1$1,2 \mathrm{~cm}$ afastadas da margem na região mediana; pedúnculo esverdeado, esverdeadoamarelado, as vezes rosado a púrpuro na base, esverdeado-vináceo a vináceo, cilíndrico, anguloso a raramente 1-carenado, 7,8-66,1 $\times$ $0,3 \mathrm{~cm}$; espata esverdeada, esverdeada com margens vináceas, esverdeada com pontos vináceos, esverdeada com estrias vináceas, esverdeado-rosada, esverdeado-avermelhada, esverdeado-vinácea, marrom-esverdeada, 
rosado-avermelhada, avermelhada, vinácea, amarelada, acastanhado-amarelada, acastanhada, cor-de-palha, membranácea, aplanada, reflexa, geralmente linear-lanceolada, lanceolada a oblongo-apiculada, persistente, decorrência 0,2-1,1 cm formando ângulo geralmente agudo a raramente obtuso com o pedúnculo, 1,7-15,5 $\times$ 0,4-2 cm; espádice esverdeado com nuanças vináceas, acastanhado-esverdeado, avermelhado-alaranjado, avermelhado, acastanhado-arroxeado, vináceo, acastanhado- vináceo, acastanhado, séssil a raramente subséssil, 3,6-19,3 cm compr., estípite, quando presente, 1-3 mm compr.; bagas maduras totalmente esverdeadas a raramente vináceos no ápice a esverdeadas, esverdeadoamarelados a esbranquiçadas para a base, tornando-se acastanhadas quando passadas, globosas com ápice e base achatados.

Material selecionado: BRASIL. RIO DE JANEIRO: Araruama, 19.II.1992, fl., L.S. Sarahyba et al. 934 (RB). Arraial do Cabo, 25.XI.1999, fl., R.J.V. Alves
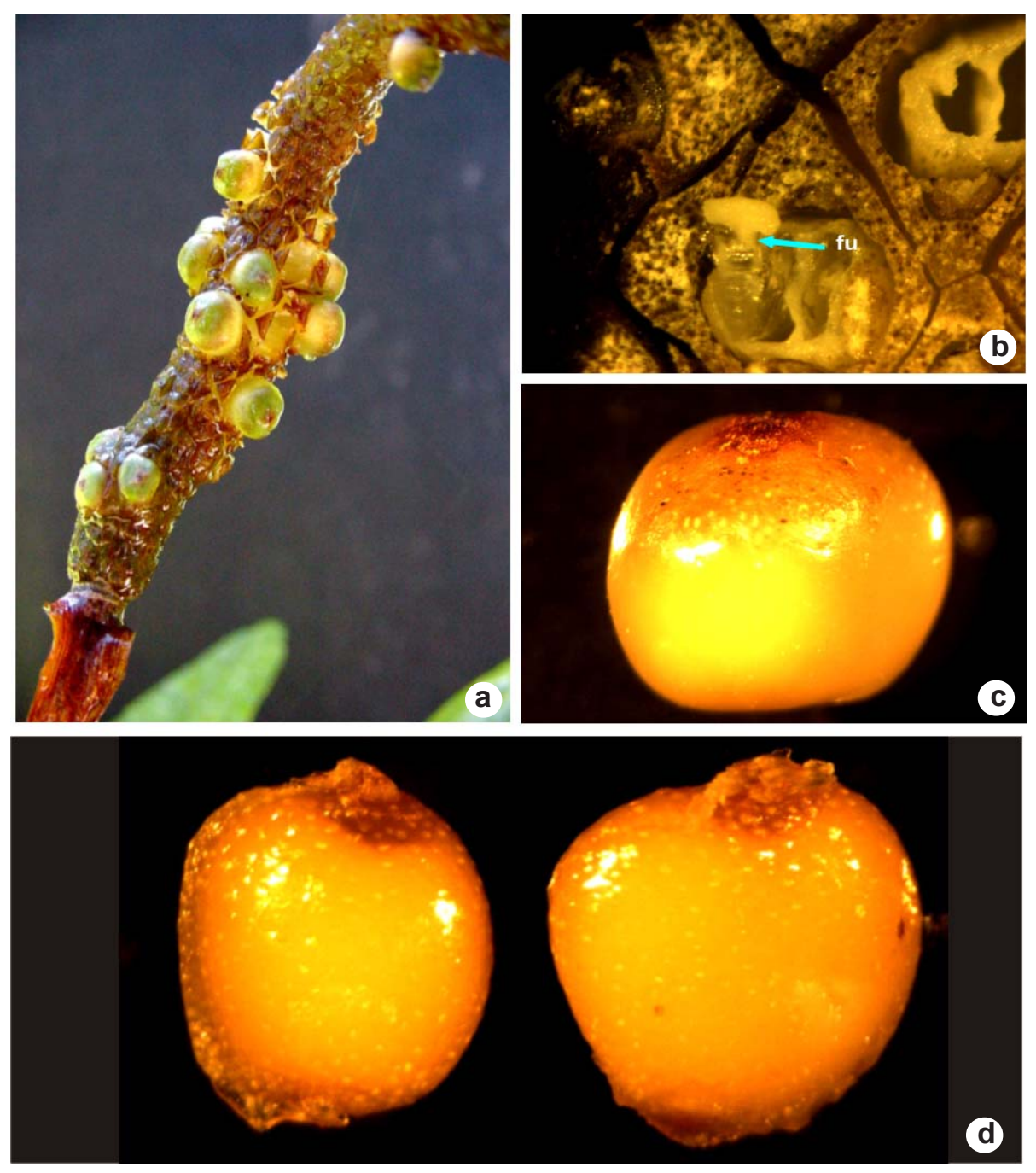

Figura 3 - a-d. A. harrisii - a. detalhe da infrutescência (Araújo s/n cultivado no JBRJ); b. detalhe do rudimento seminal, evidenciando o funículo (fu); c. fruto. d. sementes (Nadruz 1563 cultivado no JBRJ).

Figura 3 - a-d. A. harrisii - a. detail of the inflorescence (Araújo s/n cultivated at the JBRJ); b. detail of the seminal rudiment, showing the funiculum (fu); c. fruit. d. seeds (Nadruz 1563 cultivated at the JBRJ). 
6473 (R); 24.IV.2002, fl., D. Araujo 10801 (RB). Armação de Búzios, 22.V.2001, fl., D. Araujo s.n. (RB 354320). Cabo Frio, 1.VI.1989, fl. e fr., D. Araujo et al. 8973 (GUA, RB). Carapebus, 11.VII.2001, fl., M. Nadruz et al. 1430 (RB); Casimiro de Abreu, 21.III.1979, fl., P.P. Jouvin 441 (RB). Macaé, 16.XI.1988, fl., D. Araujo 8637 et al. (GUA); 15.V.1993, fl., Silva et al. 863 (SPF). Maricá, 6.V.1988, fl., M. Nadruz et al. 378 (RB); 16.II.1990, fl., D. Araujo et al. 9079 (GUA). Niterói, 27.V.1969, fl., D. Sucre 5108 et al. (RB). Rio das Ostras, 22.VIII.2001, fl., R. Marquete et al. 3034 (RB). Rio de Janeiro, 20.III.2003, fl., S.J.S. Neto et al. 1021 (RB); 9.VII.2003, fr., M. Nadruz 1563(RB). São João da Barra, 10.IX.1953, F.S. Vianna et al. 1033 (R). São Pedro da Aldeia, 9.IX.1987, fl., G. Martinelli et al. 12189 (RB). Saquarema, 8.VI.1995, fl., D. Araújo 10295 (GUA).

Anthurium harrisii é encontrada geralmente como terrestre, podendo ocorrer sobre pedras (rupícola) e, mais raramente, como hemiepífita. Espécie endêmica do estado do Rio de Janeiro, crescendo em vegetação de restinga e em costões rochosos próximos ao mar.

Pode ser reconhecida pela base geralmente obtusa a subcordada da lâmina foliar, presença de carenas na face adaxial do pecíolo e bagas esverdeadas. Diferencia-se de A. intermedium por esta apresentar base da lâmina foliar geralmente aguda a cuneada, geralmente ocorrendo nas florestas de baixada a altomontana do extremo Sul da Bahia até São Paulo. Floresce o ano todo, frutificando em janeiro, março e abril, junho, julho, outubro e novembro.

Anthurium harrisii englobava um complexo de seis variedades estabelecidas por Engler (1878) e tratava-se de um dos maiores problemas taxonômicos, em nível especifico do grupo, necessitando de atenção com relação as Araceae da Mata Atlântica, em particular. Vários espécimes vêm sendo reportados, erroneamente, como $A$. harrisii em diversas floras (Mayo 1998; NYBG 2002, 2003; CNIP 2003). Nos estados de São Paulo, Paraná e Santa Catarina possivelmente trata-se de $A$. sellowianum Kunth, por possuir lâmina foliar muito semelhante à espécie de Endlicher. $\mathrm{Na}$ Bahia provavelmente refere-se a espécie $A$. ianthinopodum (Schott ex Engl.) Nadruz \& Mayo, por sua aparência com o hábito e forma da lâmina foliar, sem falar nos estados do Acre e Pernambuco, onde é necessário trabalhos de campo para a confirmação da espécie nesses estados.

A plasticidade da lâmina foliar, juntamente com variação do hábito, da proeminência e impressão das nervuras secundárias, das formas do pedúnculo, pecíolo e nervura mediana, fez com que fossem incluídos dentro da espécie $A$. harrisii, entre outros, os seguintes indivíduos: D. Araujo s.n., M. Nadruz 1426 e R. Marquete 3034 (Coelho et al. 2004). Na dúvida sobre a permanência dos mesmos na referida espécie, sugeriu-se um estudo utilizando números e caracteres morfológicos cromossômicos. Segundo Viegas et al. (2006) as coletas já citadas apresentaram, nos estudos citogenéticos, os seguintes resultados: os espécimes D. Araujo s.n., coletado no município de Armação de Búzios, e M. Nadruz 1426, em Carapebus, possuem números cromossômicos distintos $(2 \mathrm{n}=2 \mathrm{x}=30$ e $2 \mathrm{n}=$ $4 \mathrm{x}=60$, respectivamente), e fórmulas cariotípicas diferentes $(4 m+18 s m+8 a$ e $18 m+32 s m+10 a$, respectivamente), conseqüentemente, os espécimes não são idênticos ou estão num processo de especiação, necessitando estudos mais acurados dos caracteres morfológicos vegetativos e reprodutivos, e da caracterização citogenética mais precisa, incluindo estudos de bandeamento e técnicas moleculares. Os espécimes D. Araujo s.n. e R. Marquete 3034, coletados nos municípios de Búzios e Rio das Ostras, respectivamente, possuem o mesmo número cromossômico ( $2 n=2 x=30)$ e apresentam poucas diferenças na morfologia vegetativa, podendo ser considerados provavelmenteidênticos. Considerando esses resultados e a semelhança dos caracteres morfológicos e vegetativos em relação a obra princeps e ao tipo, a princípio, os espécimes D. Araújo s.n. e R. Marquete 3034 serão mantidos em A. harrisii, porém propondo-se uma reavaliação mais apurada nas características morfológicas (vegetativas e reprodutivas), complementadas com estudos citogenéticos mais específicos. Quanto a $\mathrm{M}$. Nadruz 1426, no momento a mesma não será 
reconhecida como A. harrisii, propondo-se uma nova revisão para um melhor entendimento sobre a respectiva delimitação taxonômica. O referido espécime está sendo considerado Anthurium sp. e será estudado futuramente.

11. Anthurium hoehnei K. Krause, Notizbl. Bot. Gart. Berlin-Dahlem. 9: 271. 1925. Tipo: BRASIL. SÃO PAULO: Alto da Serra, Estação Biológica, 29.XI.1922, F.C. Hoehne 8076 (holótipo - SP!); Alto da Serra, 29.IX.1922, fl., F.C. Hoehne 8076 (isótipo -RB foto!).

Fig. 4a-b

Terrestre; caule ereto; entrenós $0,3-1,9 \mathrm{~cm}$ compr.; catafilos e profilos rosados, esverdeadovináceos a esverdeado-vináceos com a base rosada, avermelhados, acastanhados, persistentes, inteiros a levemente decompostos no ápice, acastanhados, inteiros a levemente decompostos e persistentes para a base do caule, triangulares, $0,8-5,3 \times 0,9-1,1 \mathrm{~cm}$; bainha $0,7-3,7 \mathrm{~cm}$ compr.; pecíolo esverdeado sendo esverdeadovináceo a vináceo na base das folhas novas, geralmente obtuso a raramente agudo nas folhas mais velhas ou basais a obtuso nas folhas mais novas ou apicais abaxialmente, achatado a levemente sulcado com margens raramente obtusas, geralmente agudas a subcarenadas adaxialmente, 3,9-27 ×0,25-0,3 cm; genículo mais espesso, raramente concolor, vináceo (geralmente nas folhas mais novas), mais escuro que o pecíolo, 0,6-2 cm compr.; lâmina foliar esverdeada discolor, ereta, membranácea a subcartácea em material seco, cartácea em material vivo, lanceolada, ovada a elíptica, base raramente arredondada, truncada, emarginada, geralmente cordada com seio arqueado a triangular, não pruinosa abaxialmente, com pontos glandulares em ambas as faces, ápice obtuso-acuminado, agudo curtamente apiculado, rostrado, 6,9-23,5 × 4,7-14,7 cm; nervura mediana aguda em ambas as faces a subcarenada abaxialmente e aguda adaxialmente; nervuras secundárias impressas adaxialmente, proeminentes abaxialmente, 4-8 em ambas as faces; nervuras basais raras, quando 1 , terminando na margem do terço basal da lâmina, quando 2 a mais externa terminando na margem no $1 / 4$ basal e a mais interna terminando na margem no meio da lâmina; nervuras coletoras saindo da base laminar ou raramente acima dela, 0,351,3 cm afastadas da margem; pedúnculo esverdeado, esverdeado-acastanhado, vináceo, cilíndrico, levemente anguloso a 1-3-anguloso, $9-58 \times 0,2-0,3 \mathrm{~cm}$; espata navicular, esverdeada, esverdeado-vinácea, esverdeada com nuança avermelhada a vinácea na face ventral, vinácea, membranácea, lanceolada a linear-lanceolada, ereta, formando ângulo obtuso a subagudo com o pedúnculo, 1,3-5,8 $\times 0,3-1,15 \mathrm{~cm}$, decorrência $1-3 \mathrm{~mm}$ compr.; espádice estipitado, afunilado, 1,8-6,6×0,25$0,55 \mathrm{~cm}$, estípite esverdeado, esverdeadovináceo, vináceo a esverdeado-acastanhado, $1-4,5$ cm compr.; bagas imaturas esverdeadas a vináceas.

Material selecionado: BRASIL. SÃO PAULO: Alto da Serra, V.1912, fl., H. Luderwaldt s.n. (SP 10695). Caraguatatuba, X.1988, E.L.M. Catharino 1246 (SP). Cubatão, XII.1988, M.M. Kirizawa et al. 2124 (SP). Salesópolis, VII.1954, fl., O. Handro 393 (HBR, RB); VII.1954, O. Handro 394 (SP). Santo André, 11.III.2003, fl. e fr., M. Nadruz et al. 1559 (RB); 11.III.2003, fl. e fr., M. Nadruz et al. 1560 (RB).

Anthurium hoehnei é endêmica do estado de São Paulo, distribuindo-se pela Serra do Mar, em florestas de encosta montanas, em altitudes próximas a $800 \mathrm{~m}$, com rara presença no litoral norte, no município de Caraguatatuba. A espécie é exclusivamente terrestre, sendo encontrada em locais sombreados e úmidos.

Espécie de fácil reconhecimento por apresentar catafilos e profilos persistentes e geralmente inteiros ao longo do caule, lâmina foliar geralmente ovado-lanceolada com base truncada a cordada, nervuras secundárias impressas adaxialmente e proeminentes abaxialmente, espata navicular e presença de estípite longo na espádice. Anthurium hoehnei é semelhante a $A$. marense. Esta última pode ser diferenciada da primeira por possuir lâmina foliar lanceolada, oblonga a subobovada, com base geralmente obtusa a truncada até raramente aguda e ápice subtruncado até agudo curtamente apiculado. 
Floresce nos meses de março, maio, julho a outubro, frutificando no mês de março. Novas coletas são necessárias para atualizar os registros de frutificação.
Por apresentar distribuição geográfica numa extensão menor do que $20.000 \mathrm{~km}^{2} \mathrm{e}$ tamanho da população estimada em menos que 10.000 indivíduos maduros, A. hoehnei foi
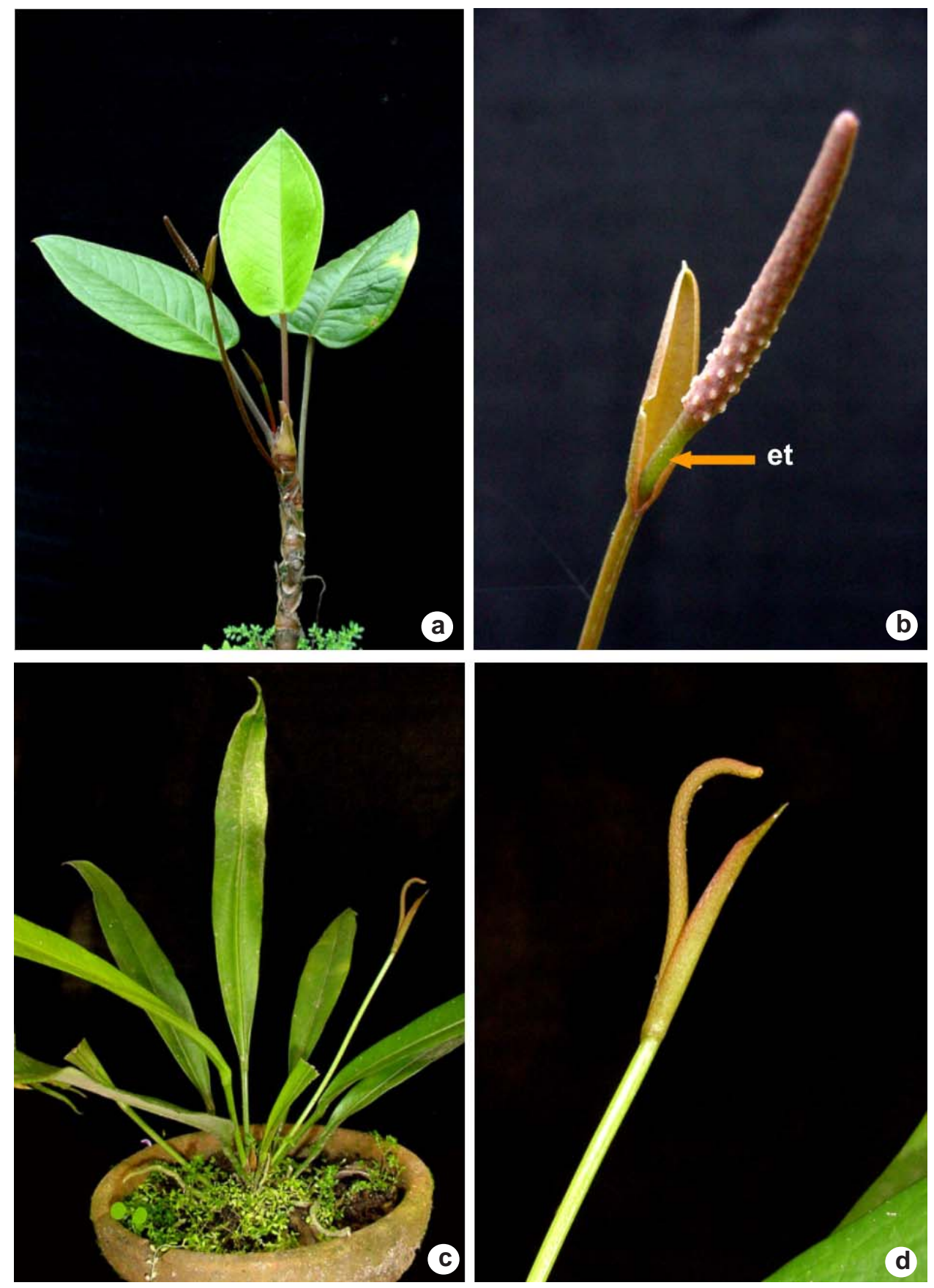

Figura 4 - a-b. A. hoehnei - a. hábito; b. inflorescência mostrando o estípite (et) (Nadruz 1546 cultivado no JBRJ). c-d. A. ianthinopodum - c. hábito; d. inflorescência em pré-antese (Nadruz 1532 cultivado no JBRJ).

Figura 4 - a-b. A. hoehnei - a. habit; b. inflorescence showing the stipe (et) (Nadruz 1546 cultivated at the JBRJ). c-d. A. ianthinopodum - c. habit; d. inflorescence before anthesis (Nadruz 1532 cultivated at the JBRJ). 
considerada vulnerável (VU), baseado nos critérios de IUCN (1998).

12. Anthurium ianthinopodum (Schott $e x$ Engl.) Nadruz \& Mayo, Taxon 56(1): 211-225. A. harrisii (Graham) G.Don var. ianthinopodum Engl., Martius, Fl. bras. 3(2): 88. 1878. Tipo: Desenho colorido de uma planta cultivada nos jardins imperiais, Palácio de Schönbrunn, Austria, Schott Icone Aroideae No. 403 (neótipo - W!, designado por Coelho, 2007).

Fig. 4c-d

[A. harrisii (Graham) G.Don var. bahiensis Mayo in Anais $34^{\circ}$ Congr. Nac. Bot. Porto Alegre. 2: 219 .1984, nom. nud.]

Epífita, ocasionalmente rupícola, semiesciófila a esciófila; caule ereto; entrenós esverdeados, 0,3-2 cm compr.; catafilos e profilos creme-rosados, acastanhados a corde-palha, inteiros a levemente decompostos no ápice, levemente decompostos a decompostos, persistentes a caducos para a base do caule, $0,6-8,2 \mathrm{~cm}$ compr.; bainha $0,8-3,5 \mathrm{~cm}$ compr.; pecíolo esverdeado, obtuso abaxialmente, plano a canaliculado com margens obtusas adaxialmente, $2,1-25,35 \times 0,4-0,5 \mathrm{~cm}$; genículo mais espesso, concolor a levemente mais claro que o pecíolo, 0,3-1,3 cm compr.; lâmina foliar esverdeada discolor a levemente concolor, ereta, subcartácea a membranácea em material seco, cartácea em material vivo, não pruinosa abaxialmente, pontos glandulares ausentes, lanceolada, linear-lanceolada, linearoblonga, levemente mais estreita em direção a base, base cuneada a aguda, ápice agudo curtamente apiculado a rostrado, 9,75-66,25 $\times 2,35-12,8 \mathrm{~cm}$; nervura mediana obtusa abaxialmente, subaguda a obtusa adaxialmente; nervuras secundárias levemente visíveis a impressas adaxialmente e levemente proeminentes a proeminentes abaxialmente, 6 24 em ambas as faces; nervura coletora saindo da base laminar ou um pouco acima dela, 0,1-1,2 cm afastadas da margem; pedúnculo $8-33 \mathrm{~cm}$ compr.; espata esverdeada, esverdeada com nuança rósea, avermelhada, deflexa, formando ângulo geralmente agudo a raramente obtuso com o pedúnculo, lanceolada a linear-lanceolada, decorrência 0,25-2,2 cm compr., 1,75-8,1 × 0,6-1 cm; espádice séssil ou curtamente estipitado, cilíndrico, esverdeado, esverdeadoacastanhado, avermelhado, vináceo, acastanhado, ferrugíneo, 2,3-16,2 cm compr., estípite 2,5 mm compr.; bagas preto-purpurescente no ápice esverdeadas a esbranquiçado para a base.

Material selecionado: BRASIL. BAHIA: Boa Nova, 15.X.2000, fl., W. Thomas et al. 12288 (CEPEC). Caravelas, 4.II.2002, fl., L. Guedes et al. 9790 (ALCB). Ilhéus, 29.VII.1993, fl., J. Jardim et al. 251 (HUEFS); 10.VIII.1994, fl., A. Carvalho et al. 4576 (RB). Itacaré, 17.X.1997, fl., J. Jardim 1146 et al. (CEPEC). Itamarajú, 3.XI.1983, fl., A. Carvalho et al. 2045 (ALCB, CEPEC). Jussari, 7.II.1998, fl., W. Thomas et al. 11721 (CEPEC). Porto Seguro, 11.I.1977, fl., R. Harley et al. 17841 (K). Una, 2.IX.1966, fl., R.P. Belém et al. 2389 (CEPEC). ESPÍRITO SANTO: Linhares, 22.X.2002, fl., $M$. Nadruz et al. 1532 (RB). São Mateus, 15.V.1977, fl., G. Martinelli et al. 2283 (RB). Santa Tereza, 30.XI.2000, fl., V. Demuner et al. 1542 (MBML, RB).

Espécie geralmente epífita, podendo ser rupícola ou terrestre em restinga arbórea, mata de tabuleiro, até floresta montana, chegando a $900 \mathrm{~m}$ alt. Distribui-se no sudeste-sul da Bahia com ocorrência também no norte do Espírito Santo.

Anthurium ianthinopodum é muito semelhante a A. longifolium, sendo diferenciada pelas folhas eretas, lâmina foliar geralmente aguda na base, bagas com o ápice purpurescente, e base esverdeadas a esbranquiçadas, e distribuição na Bahia e Espírito Santo; enquanto A. longifolium possui folhas pendentes, base da lâmina foliar geralmente obtusa, bagas totalmente avermelhadas e distribuindo-se do centro-Sul do Espírito Santo até São Paulo. É semelhante também à $A$. urvilleanum Schott diferindo por apresentar o pecíolo obtuso abaxialmente, canaliculado com margens obtusas adaxialmente contra pecíolo frequentemente carenado abaxialmente com margens sub-agudas a carenadas adaxialmente e com distribuição do Sudeste-Sul do Rio de Janeiro até o Paraná na espécie de Kunth. Floresce nos meses de janeiro, fevereiro, maio até novembro, frutificando em maio. 
13. Anthurium intermedium Kunth, Enum. Pl. 3: 70. 1841. Tipo: Desenho a lápis de um espécime no Herbário Geral de Berlin em 1840. Icone Schott no. 410 (neótipo - W!, designado por Coelho, 2007). BRASIL. RIO DE JANEIRO: Mangaratiba, Ilha da Marambaia, picada para a gruta, 40 m, 2303'40”'S 4358'47'”, 31.V.2005, M. Nadruz \& M.C. Silva 1632 (epitipo - RB, designado por Coelho, 2007). Fig. 5a-f

A. beyrichianum Kunth, Enum. Pl. 69. 1841. Tipo: Desenho a lapis de um espécime no herbário geral em Berlin preparado por Kunth de uma planta cultivada no Jardim Botânico de Berlin em 1831, Schott Icone 363 (neótipo - W!, designado por Coelho, 2007).

A. rubricaule Kunth, Enum. Pl. III: 69. 1841. Tipo: Desenho colorido de uma planta cultivada nos Jardins Imperiais, Palácio de Schönbrunn, Austria. Schott Icone 430 (neótipo - W!, designado por Coelho, 2007).

A. erythropodum Miq. in Hort. Amstelod. (Diagnoses novarum no. 8). 1853. Tipo: espécime no Miquel herbarium (Barcode U0000607, Ac cession 26631B) sem localidade e coletor (holótipo - U foto!, holótipo - W!).

A. mandiocanum Schott, Prod. Syst. Aroid.: 454. 1860. Tipo: Brasil, Rio de Janeiro, Riedel s.n. (holótipo - LE).

A. leptostachyum Schott in Oesterr. bot. Wochenbl. 5: 66. 1855. Tipo: Gravura colorida de material cultivado (nos Jardins Imperiais de Schönbrunn em Viena, Áustria). Schott Icone 415 (neótipo - W!, designado por Coelho, 2007).

Anthurium olfersianum var. acutangulum Engl., Fl. bras. 3(2): 90. 1878 - nom. illeg.

Geralmente terrestre, saxícola, rupícola e raramente epífita; caule ereto; entrenós 0,2$3,7 \mathrm{~cm}$ compr.; catafilos e profilos esverdeados, esverdeado-amarelados, amarelado-rosados, avermelhado-amarelados, avermelhados, acastanhados, cor-de-palha, inteiros quando novos, levemente decompostos a decompostos no ápice e acastanhados, cor-de-palha, marrons, raramente inteiros a decompostos, raramente persistentes a caducos para base do caule, 1$12,65 \times 2-3 \mathrm{~cm}$; bainha $0,5-9 \mathrm{~cm}$ compr.; pecíolo esverdeado com a base rosada, avermelhado a arroxeado, podendo ser vináceo no ápice a esverdeado levemente vináceo na face abaxial, raro lateralmente compresso, geralmente sub-obtuso a raramente agudo abaxialmente, achatado, subcanaliculado a sulcado, margens agudas a geralmente carenadas adaxialmente, 9,7-53,2 cm compr.; genículo concolor, levemente mais claro, mais claro, esverdeado-vináceo, da mesma grossura a mais espesso que o pecíolo, obtuso ou achatado com margens agudas a carenadas adaxialmente, obtuso abaxialmente, 0,3-2,2 cm compr., lâmina foliar esverdeada geralmente discolor a raro levemente discolor, ereta, membranácea a cartácea em material vivo e seco, não pruinosa abaxialmente, pontos glandulares ausentes, geralmente lanceolada, linear-lanceolada, geralmente mais estreitada do meio para a base a igualmente estreitada para ambas as extremidades, base aguda, cuneada, ápice subobtuso-acuminado a subobtuso-apiculado, agudo-acuminado, cuneado a rostrado, às vezes apiculado, 9,7-79,9 × 2,5-17,8 cm; nervura mediana esverdeada, esverdeadovinácea a raramente avermelhada, obtusa a raramente aguda abaxialmente, esverdeada, aguda na metade apical, achatada, obtusa a aguda para a base a geralmente totalmente obtusa adaxialmente; nervuras secundárias geralmente impressas a raramente obscuras adaxialmente, geralmente proeminentes a raramente obscuras abaxialmente, 6-26 em ambas as faces; nervura coletora saindo da base da lâmina ou um pouco acima dela, 0,2-1,5 cm afastada da margem; pedúnculo esverdeado, esverdeado com a base rosada, rosado, esverdeado da metade para o ápice e esverdeado-avermelhado para a base, esverdeado-arroxeado, avermelhado, vináceo, esverdeado-acastanhado, acastanhado, cilíndrico, levemente achatado a 1 , raramente 2 carenado, 4,8-77 cm compr.; espata esverdeadoavermelhada quando jovem, esverdeada, esverdeada com margem levemente rosada, esverdeada com centro rosado, esverdeada com manchas vináceas, esverdeado-arroxeada, esverdeado-vinácea, esverdeado-avermelhada, rosada, avermelhada, arroxeada, vinácea, 
acastanhado-avermelhada, acastanhada, amarronzada, cartácea, membranácea, lanceolada, linear-lanceolada, formando ângulo subobtuso, agudo, raramente reto com o pedúnculo, 3,1-14,4×0,5-1,8 cm, decorrência 0,15-3,1 cm compr.; espádice séssil a raro curtamente estipitado, esverdeado, avermelhado, arroxeado, arroxeado- avermelhado, vináceo, purpurescente, acastanhado-avermelhado, acastanhadovináceo, acastanhado-arroxeado, esverdeado-acastanhado, acastanhado, cilíndrico, 2,5-18,7 cm compr., estípite 1-5 mm compr., pólem alvacento; bagas imaturas e maduras esverdeadas, esbranquiçadas com ápice esverdeado.
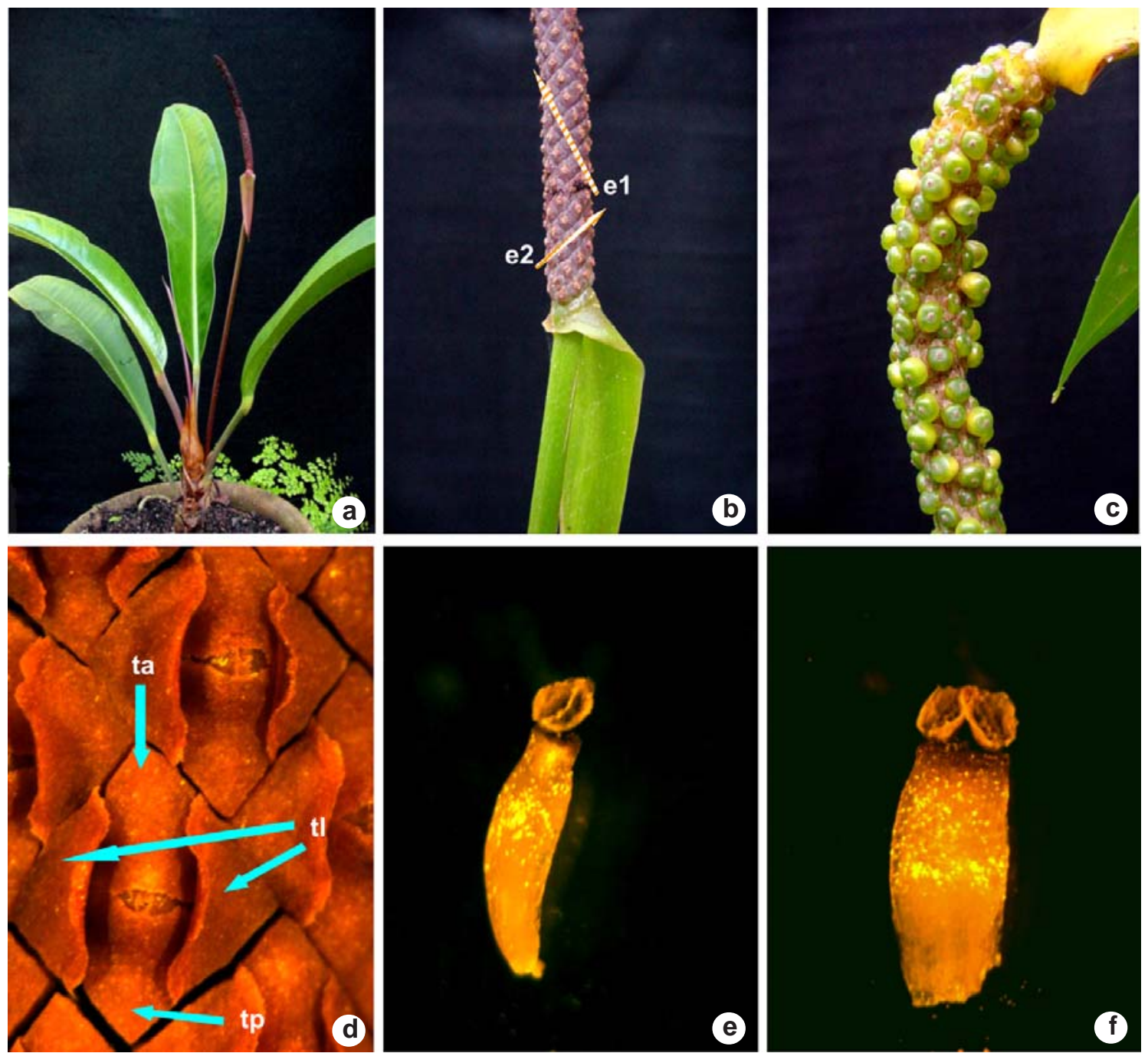

Figura 5 - a-f. Anthurium intermedium - a. hábito (Nadruz 1397 cultivado no JBRJ); b. detalhe da inflorescência, exibindo espiral principal (e1) e secundária (e2); c. detalhe da infrutescência; d. detalhe do espádice mostrando a disposição das flores, evidenciando as tépalas laterais (tl), posterior (tp) e anterior (ta) (Nadruz 1478 cultivado no JBRJ); e. estame oposto à tépala interna; f. estame oposto à tépala lateral (Nadruz 1478 cultivado no JBRJ).

Figura 5 - a-f. Anthurium intermedium - a. habit (Nadruz 1397 cultivated at the JBRJ); b. detail of the inflorescence, showing the main (e1) and secondary (e2) spirals; c. detail of the infrutescence; d. detail of the spadix showing flowers disposition; also showing lateral (tl), superior (tp) and inferior (ta) tepals (Nadruz 1478 cultivated at the JBRJ); e. stamen opposite to the internal tepal; f. stamen opposite to the lateral tepal (Nadruz 1478 cultivated at the JBRJ). 
Material selecionado: BRASIL. BAHIA: Mucuri, 2.IV.1971, fr., T.S. Santos 1534 (CEPEC). ESPÍRITO SANTO:Alfredo Chaves, 16.V.1999, fl., G Hatschbach et al. 69055 (MBM). Aracruz, 16.VII.1973, fl., D. Araújo et al. 274 (RB). Linhares, 22.X.2002, fl., $M$. Nadruz et al. 1531 (RB). Muniz Freire, 15.X.1983, fl., G. Hatschbach et al. 46873 (CEPEC). Santa Teresa, 30.VIII.2001, fl., L. Kollmann et al. 4430 (MBML). São Mateus, 2.VIII.1969, fl., D. Sucre 5475 (RB); 16.VII.1969, fl., D. Sucre 5641(RB). MINAS GERAIS: Aiuruoca, 16.II.2000, fl., E.T. Neto 2903 (BHCB). Alto Caparaó, 25.X.2001, A.C. Aguiar et al. 116 (RB); 18.VI.2002, fl., M. Nadruz 1479 et al. (RB). Conceição do Mato Dentro, 1.VIII.2002, fl., R.C. Mota et al. 1570 (BHCB). Lima Duarte, 15.VIII.2002, fl., M. Nadruz et al. 1498(RB). Pedra Dourada, fl., L. Leoni 3722 (GFJP). Santana do Riacho, 3.V.1986, fl. e fr., J.R. Pirani et al. s.n. (MBM). São Gonçalo do Rio Abaixo, 23.IV.2002, fl. efr., J.Lombardi et al.4701 (BHCB). Serro, 24.VII.2002, fl., R.C. Mota 1578(BHCB). RIODE JANEIRO: Angra dos Reis, 7.II.1996, fl., M. Nadruz et al. 1173 (RB). Campos, 10.X.1993, fl., J.M. Braga 727 (RUSU). Duque de Caxias, 22.IV.1932, J.G. Kuhlmann 15749 et al. (RB). Itatiaia, 5.II.2002, fl., M. Nadruz et al. 1452 (RB). Guapimirim, 20.XII.1995, fr., M. Bovini et al. 961 (RUSU). Magé, VII.1952, fl., A. Vidal 3336 (R). Mangaratiba, 5.VII.1969, fl., R. Braga 57(RB). Niterói, 1.VII.1982, T. Croat 53781 (GUA). Nova Friburgo, 3.XI.1992, fl., M. Nadruz et al. 785 (RB). Parati, 17.V.1995, fl., G.M. Silva et al. 20 (RB); 23.V.2001, fr., M. Nadruz et al. 1397 (RB). Petrópolis, VII.1944, fl., Dionisio 720 (RB); 27.VI.1969, fl., R. Braga 52 (RB). Rio Bonito, 28.IX.1976, fl., P.S.H. Laclette 647(R). Rio Claro, 16.III.1978, fl., G. Martinelli 4063 (RB). Rio de Janeiro, 25.IV.2001, fl., M. Nadruz 1375 et al. (RB); 11.XII.2002, fl., J.M. Braga 7141 (RB). Santa Maria Madalena, 19.X.1995, fl., R. Marquete et al. 2411 (RB). Teresópolis, 3.IV.1956, E. Pereira 1948 (RB). São Gonçalo, 7.VII.2000, fl., L.O.F. Sousa et al. 239(FFP). SÃO PAULO: Cunha, 14.XII.1996, fl., A.P. Bertoncini et al. 773 (ESA); $16 . X I I .1996$ fl., V. Souza et al. 983 (ESA). Juquiá, 9.IX.1994, fl. e fr., P.H. Miyagi et al. 236 (ESA). Pariquera-Açu, 19.X.1995, fl., N.M. Ivanauskas 503 (ESA). São José do Barreiro, 28.VI.2001, $M$. Nadruz et al. 1414 (RB). São Miguel Arcanjo, 31.X.1993, fl., P.R.L. Moraes et al. 867 (ESA). Ubatuba, 05.IX.1996, fl., V. Souza et al. 12246 (ESA).

Anthurium intermedium é uma das espécies que de maior amplitude geográfica, ocorrendo em toda a Região Sudeste além do extremo sul da Bahia, onde poder ser encontrada em áreas litorâneas, interioranas e metropolitanas.
Possui hábito geralmente terrestre e ocasionalmente saxícola, rupícola e hemiepifítico, sendo geralmente ombrófila e esciófila, mais raramente semiesciófila e semiheliófila, nas florestas de baixada, submontana, montana, sendo incomum em altitudes acima de 1600 $\mathrm{m}$. Floresce o ano todo, frutificando nos meses de fevereiro, abril a setembro e dezembro.

Esta espécie apresenta grande similaridade morfológica com o que está sendo chamado de complexo “harrisii”, por apresentar lâmina foliar lanceolada sendo mais estreitada para a base e pecíolo canaliculado com margens carenadas adaxialmente. A. intermedium caracteriza-se por apresentar pecíolo esverdeado até arroxeado, lâmina foliar geralmente aguda a longamente cuneada na base sendo mais estreitada em direção à base, nervuras secundárias geralmente impressas adaxialmente, proeminentes abaxialmente, pedúnculo cilíndrico a 1-carenado e frutos esverdeados.

A plasticidade da lâmina foliar, juntamente com variação do hábito, da proeminência e impressão das nervuras secundárias, das formas do pedúnculo, pecíolo e nervura mediana, fizeram com que fossem incluídos dentro de A. intermedium, entre outros, os seguintes indivíduos: M. Nadruz 1374, M. Nadruz 1451, M. Nadruz 1479 e J. Silva s.n. (Coelho et al. 2004). Na dúvida sobre a permanência dos mesmos em $A$. intermedium, sugeriu-se um estudo utilizando números e caracteres morfológicos cromossômicos.

Segundo Viegas et al. (2006), as coletas M. Nadruz 1374 e J. Silva s.n. (RB), por possuírem o mesmo número cromossômico e similaridade na fórmula cariotípica $(2 \mathrm{n}=4 \mathrm{x}=60$ com $18 \mathrm{~m}+24 \mathrm{sm}+18 \mathrm{a}$ e $2 \mathrm{n}=4 \mathrm{x}=60$ com $18 \mathrm{~m}$ +22sm+20a, respectivamente) são consideradas espécies iguais. Por apresentarem as características morfológicas de acordo com a descrição original de Kunth e com ocorrência em municípios próximos no estado do Rio de Janeiro, são consideradas A. intermedium. O espécime M. Nadruz 1451 (RB), que possui o mesmo número cromossômico $(2 \mathrm{n}=4 \mathrm{x}=60)$ de M. Nadruz 1374 e J. Silva s.n., mas com um 
cariótipo um pouco diferente $(8 \mathrm{~m}+52 \mathrm{~m} / \mathrm{sm} /$ a) e localização diversa, pode ser uma espécie distinta, necessitando, contudo, estudos mais detalhados em citogenética e taxonomia. Uma análise mais aprofundada será necessária, também, para a coleta M. Nadruz 1479 (RB), a qual de acordo com as diferenças no número cromossômico $(2 n=2 x=30)$ e na fórmula cariotípica $(10 m+16 s m+4 a)$, foi considerada espécie distinta de $A$. intermedium, sendo provavelmente uma espécie nova.

Coelho \& Mayo (2007), equivocadamente, elevaram a variedade $A$. olfersianum var. leptostachyum Schott ex Engler à espécie $A$. leptostachyum Schott, porém comparando os caracteres a partir das diagnoses (Schott 1855, 1860) e dos ícones de Schott (414 a 416), tais como forma agudo-carenado adaxialmente e obtuso carenado abaxialmente do pecíolo, forma lanceolada sendo retilíneo-cuneada na base laminar, coloração esverdeada das bagas e ocorrência no Rio de Janeiro, confirma-se a sinonímia de A. leptostachyum, consequentemente A. olfersianum var. leptostachyum, em relação a A. intermedium.

14. Anthurium jilekii Schott in Bonplandia 10: 5. 1862. Tipo: Gravura colorida de material cultivado (nos Jardins Imperiais de Schönbrunn em Viena, Áustria). Schott Icone 3502 (neótipo - W!, designado por Coelho, 2007); BRASIL. BAHIA: Una, $\mathrm{km} 8$ na rodovia São José da Vitória/Una, 200-250 m, 14.V.1991, S.J. Mayo et al. 833 (epitipo - RB!, designado por Coelho, 2007).

Fig. 6a-b

A. rubidum Schott ex Peyritsch in Peyritsch, J.J. Aroideae Maximilianae: 10. 1879. Carl Gerold's Sohn, Wien. Tipo: Gravura colorida de material cultivado (nos Jardins Imperiais de Schönbrunn em Viena, Áustria). Schott Icone 3527 (neótipo - W!, designado por Coelho, 2007).

A. contemptum Schott ex Peyr. in Peyritsch, J.J. Aroideae Maximilianae: 10. 1879. Carl Gerold's Sohn, Wien. Gravura colorida de material cultivado (nos Jardins Imperiais de Schönbrunn em Viena, Áustria).
Schott Icone 3494 (neótipo - W!, designado por Coelho, 2007).

Hemiepífita, ocasionalmente terrestre ou rupícola; caule ereto; entrenós $0,1-2 \mathrm{~cm}$ compr.; catafilos e profilos inteiros a decompostos no ápice, levemente decompostos a decompostos e caducos para a base do caule, rosados, esverdeado-vináceos, rosadoavermelhados, avermelhados, acastanhadoavermelhados, acastanhados, , cor-de-palha a ferrugíneos, 0,6-7,5 cm compr.; bainha 0,59,7 cm compr.; pecíolo achatado, subcanaliculado a levemente sulcado com margens raramente subagudas a geralmente carenadas adaxialmente, obtuso a raramente 1-carenado abaxialmente, esverdeado, avermelhado-esverdeado, esverdeadovináceo, avermelhado, vináceo a ferrugíneo, 3-33,6 × 0,3-0,7 cm; genículo esverdeadoamarelado, concolor, mais claro a mais escuro e mais espesso que o pecíolo, 0,3-2 cm compr.; lâmina foliar esverdeada discolor, ereta, membranácea a cartácea, não pruinosa abaxialmente, pontos glandulares ausentes, lanceolada a linear-lanceolada, igualmente estreitada para ambas extremidades a longocuneada em direção a base, ápice levemente obtuso-acuminado, agudo, agudo-acuminado, rostrado, base cuneada a aguda, 20-73,6 ×1,9$14,5 \mathrm{~cm}$; nervura mediana aguda a obtusa no comprimento total, obtusa na base a aguda para o ápice adaxialmente e carenada no comprimento total, carenada na base e roliça para o ápice abaxialmente; nervuras secundárias geralmente impressas, raro levemente impressas adaxialmente, proeminentes a levemente proeminentes abaxialmente, 5-24 em ambas as faces; nervuras coletoras saindo da base laminar ou raramente um pouco acima dela, 0,2-1,5 $\mathrm{cm}$ afastadas da margem; pedúnculo esverdeado, avermelhadoesverdeado, avermelhado, vináceo, acastanhadoavermelhado, purpurerscente-acastanhado, $10,6-51,2 \times 0,3-0,5 \mathrm{~cm}$, geralmente cilíndrico a raramente carenado; espata membranácea, lanceolada, linear-lanceolada, esverdeada com nuança rosada ou avermelhada, arroxeada, vinácea, avermelhado-ferrugínea, acastanhado- 
amarronzada a amarronzada, formando ângulo raramente obtuso a geralmente agudo com o pedúnculo, decorrência 0,3-1,6 cm compr., 2,4-10,9×0,45-1,4 cm; espádice esverdeadoacastanhado, rosado, avermelhado, arroxeado, purpurescente, vináceo, acastanhadoavermelhado, acastanhado, séssil a curtamente estipitado, cilíndrico, 2,95-12,5 cm compr., estípite 1,5-4 mm compr.; bagas globosas, distintamente apiculadas no ápice, vináceas quando jovens, arroxeado-avermelhadas, mais pálidas para a base.

Material selecionado: BRASIL. BAHIA: Amargosa, 20.IX.1996, fl., Andrade s.n. (ALCB). Boa Nova, 25.X.2001, fl., W. Thomas et al. 12622 (CEPEC). Castro Alves, 22.XII.1992, fl., H. Queiroz 3001 et al. (HUEFS). Ilhéus, 17.III.1970, fl., T.S. Santos 615 (CEPEC); 10.X.1995, fl., A. Carvalho et al. 6129 (RB). Itacaré, 10.VIII.1998, fl., J. Jardim et al. 1835 (CEPEC). Jussari, 19.IX.2002, fl., P. Fiaschi et al. 1087 (CEPEC). Macarani, 17.VIII.2001, fl., A. Carvalho et al. 7007 (CEPEC). Nova Viçosa, 23.VII.1979, fl., G. Martinelli 6036 (RB). Ribeirão do Largo, fl., A. Carvalho et al. 6989 (CEPEC). Una, 7.III.2001, fl., E.G. Gonçalves et al. 802 (CEPEC). Uruçuca, 23.IX.2000, fl., S.C. Sant'Ana et al. 1001 (CEPEC). Wenceslau Guimarães, 29.VIII.1991, fl., S.C. Sant'Ana et al. 22 (CEPEC). ESPÍRITO SANTO: Alfredo Chaves, 16.V.1999, fl., G. Hatschbach et al. 69055 (RB). Castelo, 6.XII.1956, fl., E. Pereira 2116 (RB). Domingos Martins, 7.V.1985, fl., G. Martinelli 10882 et al. (RB). Santa Maria do Jetibá, 19.IX.2002, fl., M. Nadruz et al. 1525 (RB). Santa Teresa, 18.IX.2002, fl., M. Nadruz et al. 1518 (RB).

Espécie com distribuição nos estados da Bahia e Espírito Santo. Na Bahia A. jilekii está concentrada na floresta higrófila, sul do estado, podendo, mais raramente, ser encontrada para o interior nas florestas mesofíticas. No Espírito Santo ocorre nas florestas submontana, montana e, raramente, de altitude, podendo chegar até $1700 \mathrm{~m}$ alt. Anthurium jilekii é uma espécie semi-ombrófila, ombrófila e esciófila, possuindo os hábito geralmente hemiepifítico, ocasionalmente terrestre ou rupícola.

Anthurium jilekii também é uma espécie que faz parte do "complexo harrisii", onde características da lâmina foliar, forma do

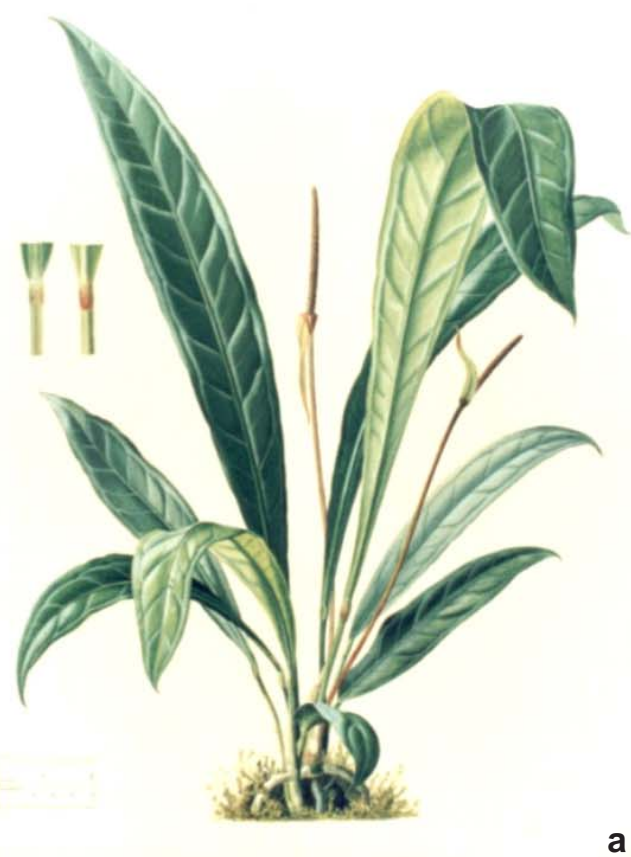

a

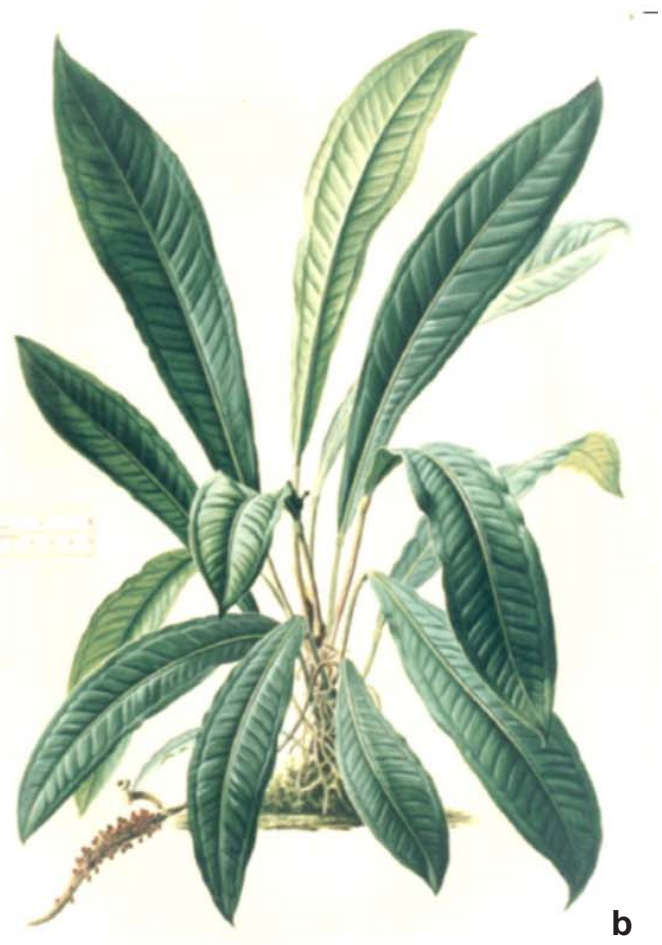

Figura 6 - a-b. Anthurium jilekii - a. hábito em floração (Icones de Schott Aroideae 3505); b. hábito em frutificação (Icones de Schott Aroideae 3494).

Figura 6 - a-b. Anthurium jilekii - a. habit, blooming (Icones de Schott Aroideae 3505); b. habit, fruiting (Icones de Schott Aroideae 3494). 
pecíolo, proeminência e impressão das nervuras secundárias são muito semelhantes à $A$. harrissi. Pode ser confundida com A. urvilleanum Schott, sendo A. jilekii diferenciada por possuir estípite até 0,4 cm compr. e bagas totalmente avermelhadas a arroxeado-avermelhadas, com distribuição nos estados do Espírito Santo e Bahia, contra estípite até 2,1 cm compr. e bagas geralmente vináceas no ápice e esverdeadas a hialinas na base, com ocorrência de Santa Catarina ao Rio de Janeiro.

Floresce de fevereiro a outubro e em dezembro, frutificando somente no mês de setembro de acordo com os registros e de acordo com Mayo (com. pess.) este período seria de janeiro até março.

15. Anthurium jureianum Catharino \& Olaio, Hoehnea 17(2): 1-6. Tipo: BRASIL. SÃO PAULO: Peruíbe, Estação Ecológica da Juréia, E.L.M. Catharino, M. M. Kirizawa, E.A. Lopes \& D. Vital 1119, 17.XI.1987 (holótipo - SP!, isótipo - RB!).

Fig. 7a

Rupícula ou terrestre; caule ereto; entrenós muito curtos; catafilos e profilos inteiros a decompostos no ápice, decompostos a caducos para a base do caule, deltóides, 22,45 cm compr.; bainha $1-5,8 \mathrm{~cm}$ compr.; folha peltada; pecíolo cilíndrico, rosado quando novo tornando-se esverdeado quando maduro, 16,2-80 ×0,3 cm; genículo $1-2,7 \mathrm{~cm}$ compr.; lâmina foliar esverdeada discolor, deflexa, cartácea, plana, não pruinosa abaxialmente, pontos glandulares ausentes, ovada, base arredondada, ápice obtuso acuminado, $12-33,2 \times 8-21,2 \mathrm{~cm}$; nervura mediana obtusa em ambas as faces; nervuras basais 3 , levemente impressas adaxialmente, sendo a mais externa terminando na margem na própria base laminar, a intermediária unindose a margem na metade da lâmina e a mais interna seguindo paralela às nervuras coletoras terminando no ápice laminar; nervuras secundárias 5-12, impressas adaxialmente, conectadas ao par mais interno de nervuras basais, afastada 1-2,5 cm da margem; pedúnculo esverdeado a rosado, cilíndrico a subcilíndrico, 16,3-41,3 ×0,3-0,5 cm; espata linear-lanceolada, lanceolada, rosada, esverdeado-arroxeada, 4,7-6 × 0,6-1 cm, formando ângulo agudo com o pedúnculo, decorrência 5 mm compr.; espádice vináceo, purpurescente, acastanhado, cilíndrico, 6-10× 0,6 cm, subséssil; bagas obovóides, com manchas purpurescentes no ápice e translúcidas na base, semente plano-convexa, obovada, verrugosa, pardacenta.

Material selecionado: BRASIL. SÃO PAULO: Peruíbe, 22.IX.1991, fl., J.V.C. Nunes et al. 1503 (SP).

A espécie é geralmente rupícola, podendo ser encontrada com o hábito terrestre em locais bastante úmidos, ensolarados, com ocorrência em florestas de baixada e submontana até 400 m altitude. Até o momento A. jureianum tem sua ocorrência exclusiva na Estação Ecológica da Juréia. Esse endemismo, segundo Catharino e Olaio (1990), foi provavelmente causado pelas diversas invasões marinhas ocorridas em períodos geológicos passados, consequentemente isolando a área do continente, favorecendo o surgimento de espécies derivadas de outras ocorrentes no mesmo local.

Anthurium jureianum é muito semelhante a A. acutum N.E. Br. em relação ao hábito, à consistência da lâmina foliar e padrão de nervação, diferenciando-se pela característica peltada da folha e a forma ovada da lâmina foliar, além de apresentar -se distribuída do estado de São Paulo até Santa Catarina em A. acutum. Anthurium jureianum é facilmente reconhecida pela folha peltada, característica muito rara, encontrada somente em mais duas espécies do gênero (A. forgetii N.E. Br. e A. peltigerum Sodiro), ambas nativas da Colômbia. Quando da publicação da espécie, Catharino e Olaio (1990) posicionaram a mesma, corretamente, na seção Urospadix, não mencionando sua locação em qualquer das subseções de Engler. Porém, ao apresentar coloração esverdeada mais clara (pálida) na face abaxial da lâmina foliar e pelas nervuras central e laterais proeminentes em ambas as faces, considera-se, portanto, a subseção Flavescentiviridia mais apropriada. 
A. jureianum floresce em setembro e novembro, frutificando em setembro.

Anthurium jureianum, segundo os critérios da IUCN (1998), até o momento encontra-se em Criticamente em Perigo (CR), por apresentar uma extensão de presença estimada em menos de $100 \mathrm{~km}^{2}$ e tamanho da população estimada em menos de 250 indivíduos maduros.

16. Anthurium langsdorffii Schott, Prodr. Syst. Aroid.: 458. 1860. Tipo: Desenho a lápis de um espécime de herbário (Brasil, Rio de Janeiro, Riedel s.n. Schott Icone no. 412 (neótipo - W! designado por Coelho, 2007). BRASIL. RIO DE JANEIRO: Mangaratiba, Reserva Rio das Pedras, trilha da lagoa seca, mata atlântica de encosta, 660 m, 16.III.2001, P. Pinto et. al. 39 (epitipo - RB! designado por Coelho, 2007).

Fig. 7b-c

Hemiepífita; caule alongado, ereto; entrenós 2-6 $\mathrm{mm}$ compr.; catafilos e profilos acastanhados em material seco, esverdeados a cor-de-palha, levemente decompostos a decompostos no ápice, decompostos a caducos para a base do caule, 0,85-4,9 cm compr.; bainha 2,35-6,85 cm compr; pecíolo esverdeado, cilíndrico, 5,1$18,3 \times 0,3-0,36$ cm compr.; genículo mais claro e levemente mais espesso que o pecíolo, 0,5$1 \mathrm{~cm}$ compr.; lâmina foliar esverdeada discolor, pendente a perpendicular ao caule, membranácea em material seco, membranácea a subcartácea em material vivo, não pruinosa abaxialmente, pontos glandulares ausentes, linear-lanceolada, ápice rostrado, base aguda a raramente obtusa, 28,2-61,9 × 2-4,6 cm; nervura mediana aguda a subaguda adaxialmente, obtusa abaxialmente; nervuras secundárias obscuras a tênues em ambas as faces, 5-16 em ambas as faces, nervuras coletoras saindo da base laminar, 1-5 mm afastadas da margem; pedúnculo esverdeado, subcilíndrico, compresso a 1-anguloso, pendente, $14,7-18,7 \times 0,19-0,21 \mathrm{~cm}$; espata esverdeada, esverdeada com nuança vinácea adaxialmente e esverdeada abaxialmente, linear-lanceolada, membranácea, formando ângulo perpendicular com o espádice, formando ângulo longamente agudo como o pedúnculo, 6,8-15,5×0,7-1,2 cm, decorrência 1,5-1,7 cm compr.; espádice esverdeado, esverdeado-vináceo, vináceo, acastanhadoesverdeado, acastanhado, cilíndrico, estipitado, 7,1-11 cm compr., estípite 0,4-1,2 cm compr.; bagas não observadas.

Material selecionado: BRASIL. RIO DE JANEIRO: Mangaratiba, 16.III.2001, fl., P. Pinto et al. 39 (RB, RUSU). Parati, 29.IV.1993, fl., R. Marquete et al. 983 (RB); 29.VI.1993, R. Marquete et al. 1058 (RB). SÃO PAULO: Bananal, 22.VI.2006, M. Nadruz et al. 1688 (RB).

A espécie de Schott é considerada endêmica das regiões sul-metropolitana, sul do estado do Rio de Janeiro e vale do Paraíba Paulista em São Paulo, ocorrendo como hemiepífita, semiesciófila, esciófila e ombrófila nas florestas submontana e montana, as vezes próxima a rios.

Anthurium langsdorffii, vinha sendo confundida com A. gaudichaudianum Kunth, uma espécie com distribuição nos estados de São Paulo a Santa Catarina. As diferenças podem ser assinaladas principalmente pelos catafilos levemente decompostos no ápice do caule, sendo menores que $5 \mathrm{~cm}$ compr., pecíolo cilíndrico com mais de 19 cm compr., lâmina foliar subdeflexa, membranácea a subcartácea e pedúnculo delgado na primeira espécie, contra catafilos inteiros no ápice do caule acima de $10 \mathrm{~cm}$ compr., pecíolo achatado a sulcado adaxialmente e obtuso abaxialmente com mais de 20 cm compr., lâmina foliar ereta, cartácea e pedúnculo virgoso. Espécie também semelhante a $A$. longifolium, diferindo pela presença de pecíolo obtuso, espata com decorrência acima de $1,5 \mathrm{~cm}$ compr., ocorrendo em florestas subomontana e montana (até $660 \mathrm{~m}$ de alt.), contra pecíolo obtuso a raramente agudo abaxialmente, achatado a sulcado com margens obtusas a raramente agudas adaxialmente, espata com decorrência até 1,4 cm compr., ocorrendo em 
florestas montana e de altitude, de 400-1700 m alt. É reconhecida pelas lâminas foliares linear-lanceoladas e pendentes, pela espata larga de coloração esverdeado-vinácea e pela presença de estípite. O registro M. Nadruz 449 presume-se ser o primeira após o neótipo. A espécie em questão floresce nos meses de março, abril, junho e dezembro, porém sem registro de frutificação. Deste modo a continuidade de coletas nas áreas de distribuição de A. langsdorffii é de vital importância para os registros de frutificação.

Anthurium langsdorffii encontra-se Em Perigo (EN), pelos critérios da IUCN (1998), por apresentar uma área de ocupação estimada em menos de $500 \mathrm{~km}^{2}$ e uma população estimada em menos de 2.500 indivíduos maduros.
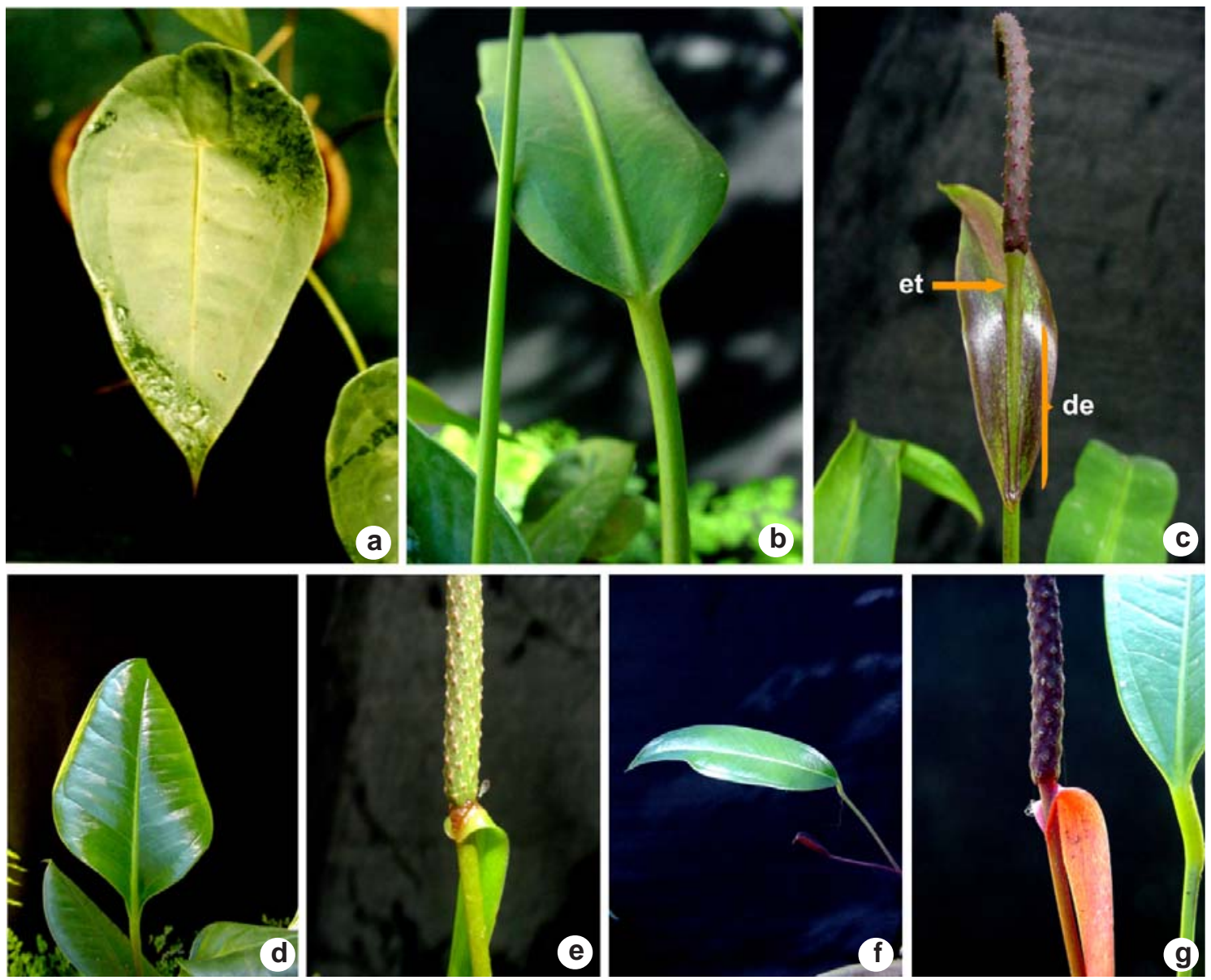

Figura 7-a. Anthurium jureianum - a. lâmina foliar (Catharino s/n cultivado no Instituto de Botânica de SP). b-c. A. langsdorffii - b. detalhe da folha, evidenciando forma do pecíolo; c. inflorescência enfatizando a longa decurrência (de) da espata, e ângulo agudo entre o pedúnculo e a estípite (et) (Pinto 39 cultivado no JBRJ). d-e. A. loefgrenii - d. lâmina foliar, evidenciando base estreitada; e. detalhe da inflorescência, evidenciando o ângulo obtuso da espata em relação ao pedúnculo (Nadruz 1488 cultivado no JBRJ). f-g. A. longicuspidatum - f. lâmina foliar; g. detalhe da inflorescência, mostrando a espata (Nadruz 1552 cultivado no JBRJ).

Figura 7 - a. Anthurium jureianum - a. leaf blade (Catharino s/n cultivated at the Botanical Institute of São Paulo). b-c. A. langsdorffii - b. detail of the leaf, showing the shape of the petiole; c. inflorescence, detail of the long decurrent spathe, and the acute angle between the peduncle and the stipe (Pinto 39 cultivated at the JBRJ). d-e. A. loefgrenii - d. leaf blade, showing the narrowed base; e. detail of the inflorescence, showing the obtuse angle formed between the spathe and peduncle (Nadruz 1488 cultivated at the JBRJ). f-g. A. longicuspidatum - f. leaf blade; g. detail of the inflorescence, showing the spathe (Nadruz 1552 cultivated at the JBRJ). 
17. Anthurium loefgrenii Engl., Pflanzenr. 21: 165. 1905. Tipo: Südbrasilianische Provinz: San Paulo, Porto Pegulvo (“pequeno”), Praia Grande, in der restinga 15.X.1898, fl., A. Loefgren 4065 (holótipo - B!, isótipo - SP!, fotoisótipo-RB!).

Fig.7d-e

A. itanhaense Engl., Das Pflanzenr. 21: 166. 1905. Tipo: Südbrasilianische Provinz: San Paulo, im littoralen Urwald von Conc. De Itanhaën X, A. Loefgren \& G. Edwall n. 1577 (holótipo - B†, isótipo - SP!).

Terrestre, raramente rupícola; caule alongado, decumbente a semi-decumbente; entrenós $0,15-2,3 \mathrm{~cm}$ compr.; catafilos e profilos esverdeados, esverdeado-amarelados, creme com manchas avermelhadas na base, acastanhados, cor-de-palha, persistentes, inteiros, levemente a raramente decompostos no ápice, acastanhados a cor-de-palha, raramente inteiros a geralmente decompostos, persistentes a caducos para a base do caule, triangulares, $0,8-8,8 \times 3,7-6 \mathrm{~cm}$; bainha $0,5-$ $4,35 \mathrm{~cm}$ compr.; pecíolo esverdeado, raramente esverdeado com leve nuança avermelhada, cilíndrico, obtuso abaxialmente, levemente achatado, achatado a raro levemente sulcado com margens geralmente obtusas a subagudas, raramente agudas e subcarenadas adaxialmente, 2,6-36,6 cm compr.; genículo rosado em folha jovem, esverdeado concolor, raramente com nuança avermelhado a levemente avermelhado, raro levemente mais escuro a mais claro, mais espesso que o pecíolo, 0,4-2,8 cm compr.; lâmina foliar esverdeada levemente discolor a discolor, ereta, membranácea a cartácea em material vivo e seco, não pruinosa abaxialmente, pontos glandulares ausentes, igualmente estreitada para ambas as extremidades a mais estreitada para a base, geralmente elíptica a lanceolada, ápice obtuso-acuminado, agudo a rostrado, base geralmente cuneada, curtamente estreitada na extremidade, e raramente subaguda, 9,7-45,5 × 4-25,4 cm; nervura mediana obtusa a carenada do meio para a base e obtusa do meio para o ápice abaxialmente, aguda a raramente obtusa no comprimento total, raramente obtusa do meio para a base a levemente achatada na extremidade basal tornando-se obtusa a aguda para o ápice adaxialmente, nervuras secundárias levemente impressas a impressas adaxialmente, proeminentes a levemente proeminentes abaxialmente, 5-18 em ambas as faces, nervuras coletoras nascendo na base da lâmina ou um pouco acima dela, 0,3-2,3 cm afastadas da margem; pedúnculo cilíndrico a raramente 1-carenado, avermelhado quando jovem, esverdeado-amarelado, esverdeado, esverdeado com estrias avermelhadas, esverdeado-rosado, avermelhado sendo esverdeado para o ápice, acastanhadoesverdeado, rosado, avermelhado a vináceo, acastanhado-vináceo, 12,5-51,4 cm compr.; espata membranácea, esverdeada, cremevinácea, amarelado-esverdeada com margem avermelhada, esverdeada com leve nuança rosada, esverdeada com leve nuança avermelhada, esverdeada com margens vináceas, esverdeada sendo levemente arroxeada no centro e nas margens, esverdeado-rosada, rosada, esverdeado-avermelhada, esverdeada sendo acastanhada no centro e nas margens, arroxeada, vinácea, acastanhado-esverdeada, acastanhada, lanceolada a linear-lanceolada, 2,2-10,2 × 0,3-2 cm, formando ângulo geralmente obtuso a raramente reto com 0 pedúnculo, decorrência $0,2-1,5$ cm compr.; espádice esverdeado, alaranjado, esverdeadovináceo, arroxeado, vináceo, acastanhadoavermelhado, acastanhado-vináceo, acastanhado, séssil a raro curtamente estipitado, 2,4-14,5 cm compr., estípite 1-3 mm compr.; bagas acastanhadas quando imaturas, acastanhadas, esverdeado-amarronzadas a amarronzadas.

Material selecionado: BRASIL. PARANÁ: Antonina, 5.VII.1967, fl., G. Hatschbach et al. 16655 (MBM, US). Curitiba, 15.IX.1953, fl., R. Reitz 5745 (HBR). Guaraqueçaba, 20.XI.1974, fl., G. Hatschbach 35494 (MBM). Guaratuba, 27.XII.1971, fl., G. Hatschbach 28534 (MBM). Matinhos, 14.IV.1974, fl., R. Kummrow 558 (MBM); 10.X.2002, J. Sonehara 23 (MBM). Morretes, 10.IX.1986, fl., J. Cordeiro et al. 360 (MBM). Paranagua, 7.V.1999, fl., E. Barbosa et al. 267 (MBM, RB). Pontal do Paraná, 15.IX.1973, 
fl., G. Hatschbach 32540 (MBM, NY). Quatro Barras, 22.VII.1993, fl., O.S. Ribas et al. 546 (MBM). SANTA CATARINA: Araquari, 10.VIII.1953, fr. e fl., R. Reitz et al. 905 (HBR). Campo Alegre, 24.III.1961, fl., R. Reitz et al. 10923 (HBR). Garuva, 22.XII.1957, fl., R. Reitz et al. 5843 (HBR); 7.V.1989, fl., G. Hatschbach et al. 52778 (MBM). Itajaí, 28.V.1953, fl., R. Reitz et al. 758(HBR). SÃO PAULO: Bertioga, 20.V.1999, fl., D. Sampaio et al. 289 (USC). Cananéia, 16.VII.2002, fl., M. Nadruz et al. 1491 (RB). Iguape, 7.I.1999, fl. e fr., E.R. Batista et al. 60 (ESA). Itanhaem, 13.IV.1996, fl., V.C. Souza et al. 11129 (ESA, HRCB). Pariquera-Açu, 22.VI.1996, fl., N.M. Ivanauskas et al. 1570 (HRCB). Peruíbe, 9.X.1995, fl. e fr., V.C. Souza et al. 9291 (ESA). Praia Grande, 1.V.1956, fl., O. Handro 572 (RB). Ubatuba, 5.IX.1996, fl., V.C. Souza et al. 12244 (ESA).

Anthurium loefgrenii é encontrada com hábito terrestre na maioria das vezes, sendo que o caule apresenta-se subdecumbente. Cresce em ambiente úmido e sombreado nas matas de restinga, com raras exceções nas matas de encosta montana, alcançando altitudes entre 900 e 1200 m em três municípios nos estados do Paraná e Santa Catarina. Distribui-se nas Regiões Sul e Sudeste ocorrendo desde o estado de São Paulo até Santa Catarina.

A espécie pode ser reconhecida pelo caule semidecumbente e pela base estreitadocuneada da lâmina foliar. Apresenta-se extremamente semelhante à $A$. parasiticum (Vell.) Stellfeld, porém diferencia-se pelos caracteres e distribuição acima mencionados, contra caule ereto e base da lâmina foliar geralmente truncada a obtusa com ocorrência desde o extremo sul da Bahia até São Paulo (onde as coletas resumem-se a quatro municípios). Comentários a respeito da sinonimização com A. itanhaense Engler e a devida correção do nome científico, consultar (Coelho \& Mayo 2007). O material Croat 53788 (GUA), na etiqueta da exsicata, informa que as bagas são de coloração alaranjada. Já os dados relativos à coloração do fruto em $A$. loefgrenii, a partir de dados de etiqueta, registra as cores esverdeado-acastanhada, acastanhada a amarronzada para as bagas. Para um registro correto sobre a real tonalidade do fruto é recomendável novas coletas nas localizações de ocorrência da referida espécie uma vez que esta característica é importante na delimitação re reconhecimento das espécies

Floresce o ano todo, frutificando entre julho e novembro e no mês de janeiro.

18. Anthurium longicuspidatum Engl., in Bot. Jahrb. Syst. 25: 415. 1898. Tipo: BRASILIA ou F. Sellow s.n. (holótipo - B!) Fig. 7f-g

Terrestre, raramente hemiepífita; caule ereto; entrenós 0,3-1,5 cm compr.; catafilos e profilos rosados a acastanhados, inteiros, levemente decompostos a decompostos no ápice, acastanhados, levemente decompostos a decompostos, persistentes a caducos para a base do caule, $1,25-7,3 \times 2,1 \mathrm{~cm}$; bainha $0,7-$ 2,2 cm compr.; pecíolo esverdeado, avermelhado, esverdeado-rosado a esverdeado levemente avermelhado na base em folha nova, cilíndrico a levemente achatado a raramente sulcado com margens obtusas a subagudas na face adaxial, 4,8-22 × 0,2 cm; genículo sulcado com margens agudas adaxialmente, concolor, levemente mais claro a mais escuro, levemente mais espesso que o pecíolo, 0,4-1,4 cm compr.; lâmina foliar esverdeada levemente discolor a discolor, opaca, ereta, membranácea a levemente cartácea em material seco, cartácea em material vivo, não pruinosa abaxialmente, pontos glandulares ausentes, lanceolada a subovada, levemente mais estreita em direção ao ápice, ápice obtuso-acuminado com apículo (0,1-0,3 cm compr.), rostrado curtamente apiculado, base geralmente aguda, raramente subtruncada a arredondada, 8,9-19,6 × 2,1$8,7 \mathrm{~cm}$; nervura mediana aguda adaxialmente e obtusa abaxialmente; nervuras secundárias geralmente impressas a raro levemente impressas adaxialmente, geralmente proeminentes a raro levemente proeminentes abaxialmente, 5-15 em ambas as faces; nervuras coletoras saindo da base da lâmina, 1,5-8 mm afastadas da margem; pedúnculo cilíndrico a raro levemente achatado, rosado, vináceo, 5,7-18,5 $\times 0,15 \mathrm{~cm}$; espata subdeflexa a deflexa, aplanada, membranácea, creme-rosada, rosada, rosado-vinácea, avermelhada, vinácea, 
acastanhado-esverdeada, acastanhada, linearlanceolada, lanceolada, acuminada, decorrência 1-6 mm formando ângulo obtuso a subagudo com o pedúnculo, $1-5,4 \times 0,45-0,8 \mathrm{~cm}$; espádice séssil a curtamente estipitado, cilíndrico, acastanhado, acastanhadoavermelhado, vináceo, 1,2-5,4 cm compr., estípite vinácea, 1-3 mm compr.; bagas imaturas esverdeadas com pontos avermelhados no ápice.

Material selecionado: BRASIL. RIO DE JANEIRO: Parati, 14.IV.1994, R. Marquete 1634 (RB). SÃO PAULO: 29.XI.2002, fl., V.M. Higashi 7 et al. (UNISA). Cubatão, 2.IX.1986, fl., M. Kirizawa 1743 (SP). Cunha, 13.XII.1996, fl., Souza et al. 864 (ESA). Santo André, 11.III.2003, fl. e fr., M. Nadruz et al. 1552 (RB); 11.III.2003, fl., M. Nadruz et al. 1558 (RB). São Paulo, 14.VIII.1895, fl., G. Edwall 3075 (RB - foto); 28.IX.1920, fl., F. Hoehne s.n. (SP); São Sebastião, 7.X.1988, fl., E.L. Catharino 1247 (SP).

A espécie possui o hábito terrestre, raramente hemiepífita, crescendo em áreas muito úmidas e sombreadas. Anthurium longicuspidatum até o momento distribuía-se nas regiões metropolitana e vale do Paraíba paulista, em altitudes acima de $750 \mathrm{~m}$. Atualmente um novo registro, para o estado do Rio de Janeiro, é conhecido. O espécime R. Marquete 1634 foi coletado no município de Parati, região sul do estado, numa altitude bem abaixo do padrão da espécie (60 m).

Anthurium longicuspidatum pode ser reconhecida pelo seu hábito terrestre, com as folhas eretas e inflorescência geralmente avermelhada a vinácea. Pode ser confundida com A. organense Engl., diferenciando-se por apresentar nervuras secundárias geralmente impressas e proeminentes nas duas faces da lâmina, inflorescência rosada a vinácea e espádice geralmente séssil ou com estípite até 0,3 cm compr., contra nervuras secundárias obscuras a pouco visíveis nas faces da lâmina, inflorescência esverdeada, esverdeadovinácea a vinácea e espádice com estípite até 1,6 cm compr., com ocorrência nos estados do Rio de Janeiro e Espírito Santo.

Floresce nos meses de fevereiro a abril e julho a dezembro, frutificando em março.
Por possuir uma extensão da presença estimada menor que $20.000 \mathrm{~km} 2$ e tamanho da população estimada em menos de 10.000 indivíduos maduros, A. longicuspidatum é considerada Vulnerável (VU) pelos critérios da IUCN (1998).

19. Anthurium longifolium (Hoffmanns.) G. Don in Sweet, Hort. Brit. Ed. 3: 633. 1839. Tipo: Desenho colorido de uma planta cultivada nos Jaridns Imperiais, Palácio de Schönbrunn, Austria. Icone Schott No. 3507 (neótipo W! designado por Coelho, 2007). BRASIL. RIO DE JANEIRO: Teresópolis, picada para a Pedra do Sino, mata atlântica de encosta pertubada, 1165 m, 27.XII.2001, M. Nadruz \& Breno 1502 (epitipo - RB! designado por Coelho, 2007).

Fig. 8a-c

A. longifolium var. elongellum Engl. in Martius, Fl. Bras. 3(2): 87. 1878. Tipo: Desenho a lápis de um espécime no herbário geral do Jardim Botânico de Berlin, feito de uma planta cultivada no Jardim Botânico de Berlin, em 1831, dentro do nome "Pothos elongella". Icone Schott No. 420 (neótipo - W! designado por Coelho, 2007).

Epífita, raramente terrestre, saxícola e rupícola; raízes amarronzadas; caule curto, ereto; entrenós $0,1-1,6 \mathrm{~cm}$ compr.; catafilos e profilos esverdeados, arroxeadoavermelhados, acastanhados, cor-de-palha, levemente decompostos a geralmente decompostos no ápice, acastanhados, inteiros, levemente decompostos a decompostos, persistentes a caducos em direção a base do caule, $1,1-10,3 \mathrm{~cm}$ compr.; bainha $0,8-8,8 \mathrm{~cm}$ compr.; pecíolo avermelhado em folha jovem tornando-se esverdeado, obtuso a raramente agudo abaxialmente, achatado, sulcado a freqüentemente levemente sulcado com margens geralmente obtusas, subagudas a raramente agudas adaxialmente, 1,6-26,5 cm compr.; genículo mais claro, raramente mais escuro a concolor e mais espesso que o pecíolo, 0,3-2,5 cm compr.; lâmina foliar esverdeada discolor a levemente discolor, perpendicular ao caule, membranácea a cartácea em material 

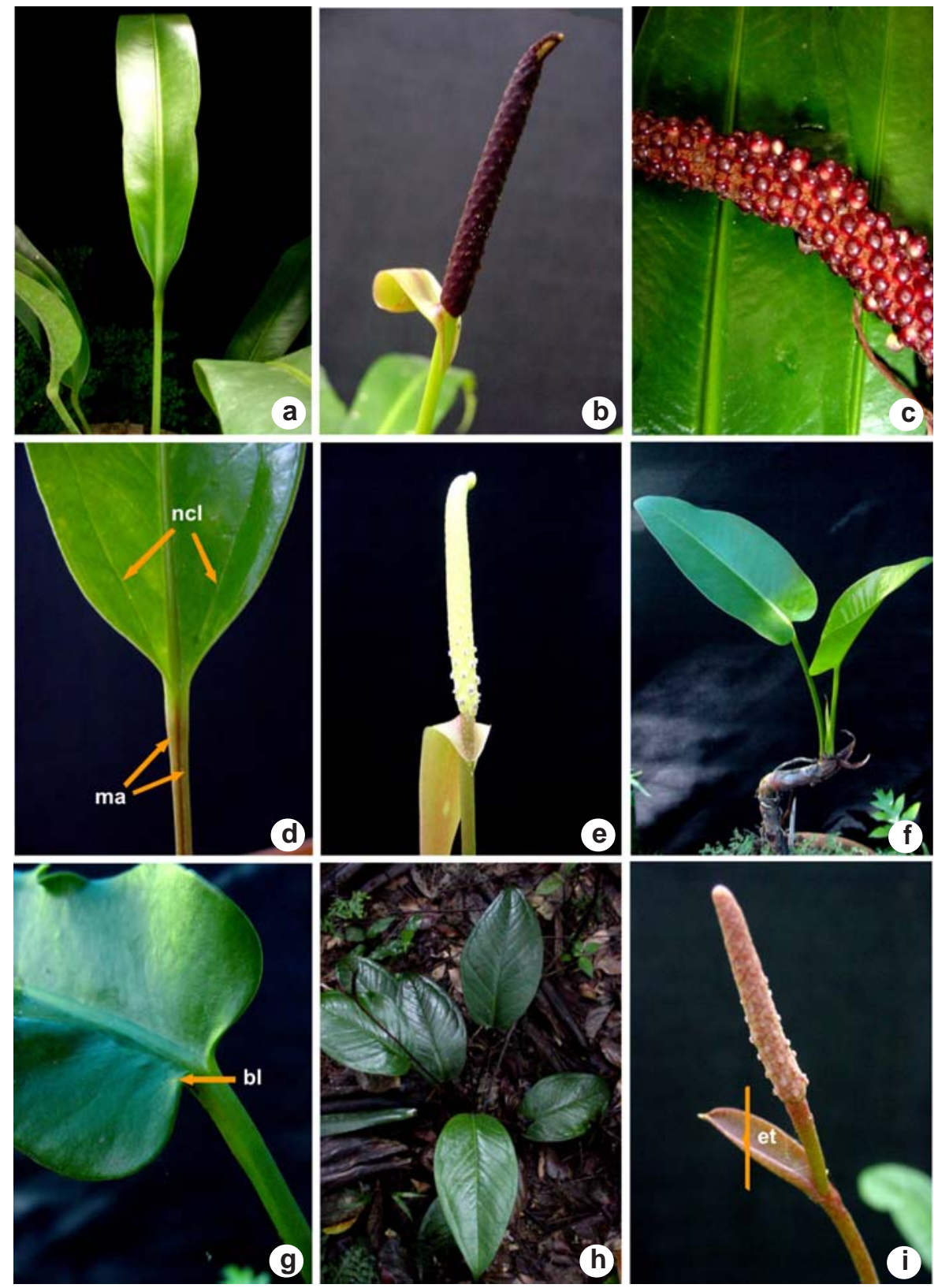

Figura 8 - a-c. Anthurium longifolium - a. detalhe da lâmina foliar (Nadruz 1390 cultivado no JBRJ); b. inflorescência, note espata formando ângulo agudo na inserção com o pedúnculo; c. detalhe da infrutescência (Nadruz 1386 cultivado no JBRJ). d-e. A. lucioi - d. folha mostrando a nervura coletora (ncl) e pecíolo sulcado com margens obtusas adaxialmente (ma) (Nadruz 1404 cultivado no JBRJ); e. inflorescência acrópeta, deflexa (Nadruz 1416 cultivado no JBRJ). f-g. A. luschnathianum -f. hábito (Nadruz 1539 cultivado no JBRJ); g. detalhe da base laminar (bl) (Nadruz 1538 cultivado no JBRJ). h-i. A. marense - h. hábito; i. inflorescência, evidenciando longo estípite (et) e a espata navicular (Nadruz 1549 cultivado no JBRJ).

Figura 8 - a-c. Anthurium longifolium - a. detail of the leaf blade (Nadruz 1390 cultivated at the JBRJ); b. inflorescence, note the acute angle formed by the insertion of the spathe on the peduncle; c. detail of the infrutescence (Nadruz 1386 cultivated at the JBRJ). d-e. A. lucioi - d. leaf showing the collector vein (ncl) and the sulcate petiole with obtuse adaxial margin (ma) (Nadruz 1404 cultivated at the JBRJ); e. acropetal inflorescence, deflected (Nadruz 1416 cultivated at the JBRJ). f-g. A. luschnathianum - f. habit (Nadruz 1539 cultivated at the JBRJ); g. detail of the leaf base (bl) (Nadruz 1538 cultivated at the JBRJ). h-i. A. marense - h. habit; i. inflorescence, showing the long stipe (et) and the navicular spathe (Nadruz 1549 cultivated at the JBRJ). 
vivo, membranácea a subcartácea em material seco, não pruinosa abaxialmente, pontos glandulares ausentes, lanceolada, geralmente linear-lanceolada, base frequentemente obtusa a aguda, ápice rostrado, raramente agudoapiculado, $10,3-67,95 \times 1,8-8,6 \mathrm{~cm}$; nervura mediana subaguda a obtusa abaxialmente, aguda, obtusa a subaguda do meio para o ápice adaxialmente; nervuras secundárias levemente proeminentes abaxialmente, levemente impressas adaxialmente a obscuras em ambas as faces, 5-22 em ambas as faces; nervuras coletoras saindo da base da lâmina ou, raramente, pouco acima dela, 0,15-1 cm afastadas da margem; pedúnculo esverdeado, esverdeado-acastanhado, vináceo, acastanhado, cilíndrico a raramente 1-anguloso, 8,7-40,1 cm compr.; espata linear-lanceolada, creme, esverdeado-esbranquiçada, esverdeada, as vezes rosada adaxialmente ou com manchas vináceas, avermelhada, vinácea, cor-de-palha, acastanhada a amarronzada (quando passada), às vezes caduca $1,9-14,2 \times 0,2-0,9 \mathrm{~cm}$, formando ângulo agudo a subobtuso com o pedúnculo, decorrência 0,1-1,4 cm compr.; espádice avermelhado, vináceo, purpurescente, acastanhado (quando envelhecido), 2-21,2 cm compr., séssil ou com presença de estípite com 1-7 mm compr.; bagas avermelhadas a vináceas ou vináceas no ápice e rosadas a avermelhadas para a base.

Material selecionado: BRASIL. ESPÍRITO SANTO: Itarana, 7.VIII.2002, fl., L. Kollmann et al. 5675 (MBML). Muniz Freire, 15.X.1983, fl., G. Hatschbach et al. 46873 (MBM). MINAS GERAIS: Araponga, 19.VI.2002, M. Nadruz et al. 1480 (RB). Carangola, 16.X.1999, fl. e fr., L. Leoni et al. 4273 (GFJP). Coronel Pacheco, fl., E.P. Heringer 1598 (SP). Fervedouro, 10.VII.1999, fr., J. Lombardi 3125 (BHCB); 5.VI.2002, fl., L. Leoni 5024 et al. (GFJP). Rio Novo, IX.1895, fl., C.A. Schwacke 11907 (RB). RIO DE JANEIRO: fl., Widgren 1844-1846(S); 1880, fl., A. Glaziou 16511 (P). Guapimirim, 16.VIII.1995, fl. e fr., M. Bovini 851 et al. (RUSU). Macaé, 22.X.1985, fl., M. Leitman et al. 54 (RB). Magé, V.1952, fl., A. Vidal 2541 (R); 28.V.1984, fl., M.B. Casari et al. 1158 (GUA). Nova Friburgo, 2.V.2001, fl., M. Nadruz et al. 1390 (RB). Paty do Alferes, 21.VII.1969, fl., R. Braga 61 (RB). Petrópolis,
08.VI.1978, fl., G. Martinelli 4555 (RB). Rio Bonito, 13.VIII.1986, fl., G. Martinelli 11629 et al. (RB). Santa Maria Madalena, 22.II.1983, fl., H.C. Lima 1876 et al. (RB). Teresópolis, 27.XII.2001, fl. e fr., M. Nadruz et al. 1502 (RB). SÃO PAULO: Eldorado, 4.IX.1995, fr., V.C. Souza et al. 9115 (ESA).

Possui o hábito geralmente epifítico, as vezes rupícola e saxícola, em locais úmidos e sombreados, nas florestas submontana e, mais frequentemente, montana e de altitude até cerca de 1700 m altitude. A espécie em questão possui uma distribuição ampla, desde o centrosul do Espírito Santo, na zona da mata e Sul de Minas Gerais, Rio de Janeiro e num único município do litoral paulista, Eldorado.

Espécie frequente, sendo de fácil reconhecimento por apresentar o hábito geralmente epifítico, pecíolo obtuso abaxialmente, frequentemente levemente sulcado com margens obtusas adaxialmente, lâmina foliar pendente e bagas avermelhadas a vináceas. Anthurium longifolium pode ser confundida com A. langsdorffii Kunth conforme já mencionado. Floresce o ano todo e frutifica nos meses de junho a fevereiro.

20. Anthurium lucioi Nadruz, Pabstia 15(2): 1-9. 2004. Tipo: BRASIL. MINAS GERAIS: Araponga, Serra do Araponga, Fazenda Neblina, 30.IX.1995, fl., L. Leoni 3095 (holótipo - GFJP!).

Fig.8d-e

Terrestre, raramente rupícola; caule ereto; entrenós curtos, $0,3-2,8 \mathrm{~cm}$ compr.; catafilos e profilos inteiros no ápice, esverdeados, acastanhados a decompostos no ápice, acastanhados, levemente decompostos a caducos para a base do caule, 1,2-7,9 cm compr.; bainha $0,7-3 \mathrm{~cm}$ compr.; pecíolo esverdeado, esverdeado-vináceo a vináceo para a base, obtuso abaxialmente e compresso lateralmente, obtuso, levemente achatado no terço basal e sulcado para o ápice a totalmente levemente sulcado a sulcado com margens obtusas adaxialmente, 4,8-55,6 × 0,2 cm; genículo levemente mais claro a mais claro, concolor, mais escuro a levemente avermelhado e mais espesso que o pecíolo, cilíndrico abaxialmente e sulcado adaxialmente, 0,7-1,4 
cm compr.; lâmina foliar esverdeada discolor, ereta, cartácea em material vivo e seco a membranácea a subcartácea em material seco, não pruinosa abaxialmente, pontos glandulares ausentes, ovada, ovado-lanceolada, lanceolada a raramente elíptica, base obtusa, truncada, subcordada, geralmente curtamente estreitada, ápice obtuso-acuminado, apiculado, agudo, rostrado, 10,55-41,6 × 4,2-12,8 cm; nervura mediana obtusa abaxialmente, aguda a levemente achatada na base adaxialmente; nervura basal raramente 1 saindo da base e terminando na margem da metade inferior da lâmina; nervuras secundárias geralmente impressas a raro levemente impressas adaxialmente, geralmente proeminentes a raro levemente proeminentes abaxialmente, 5-11 em ambas as faces; nervuras coletoras saindo da base da lâmina ou um pouco acima dela, retilíneas no terço inferior e logo após curvilíneas paralelas a margem, 0,3-1,7 cm afastadas da margem; pedúnculo vináceo quando novo, esverdeado, esverdeadoavermelhado no ápice com a base esverdeada levemente alaranjada, esverdeado-avermelhado, esverdeado-vináceo, avermelhado, cilíndrico a anguloso, cilíndrico na base a levemente achatado para o ápice, 16-66,8 cm compr.; espata membranácea, alva, esverdeado-alvacenta, esverdeada, vinácea, passada amareladorosada a amarronzada, persistente, lanceolada, linear-lanceolada, 2,8-8,8 × 0,5-1,35 cm, formando ângulo obtuso a agudo com o pedúnculo, decorrência 0,35-1,6 cm compr.; espádice esverdeado, acastanhado-esverdeado, acastanhado a cor-de-palha, cilíndrico, 3,2-14,5 cm compr., estipitado, estípite 0,5-4,2 cm compr.; bagas imaturas com o ápice esverdeado, esverdeado-acastanhados, esverdeados a acinzentados.

Material selecionado: BRASIL. MINAS GERAIS: Araponga, 30.IX.1995, fl., J. Lombardi 961 fr. (RB, MBM); 19.VI.2002, M. Nadruz et al. 1481 (RB). Juiz de Fora, 23.XI.1991, fl., M.C. Brügger et al. s.n. (CESJ). Lima Duarte, 24.VIII.1987, fl., F.R.S. Pires et al. s.n. (RB); 12.VIII.2002, fl., M. Nadruz et al. 1496 (RB). Passa Vinte, fr., A. Salino et al. 5926 (BHCB). Santa Rita, I.1895, fl., C.A. Schwacke 11324 (RB).
SÃO PAULO: Bananal, 7.I.1997, fl., P.R.C. Farág et al. 465 (RB). Santa Isabel, 13.IX.1956, fl., O. Handro 606 (SP). São José do Barreiro, 27.VI.2001, fl., $M$. Nadruz et al. 1413 (RB); 28.VI.2001, fl. e fr., $M$. Nadruz et al. 1416 (RB).

Espécie geralmente terrestre, raramente rupícola. Ocorre em floresta altomontana de encosta atlântica entre 900-1600 m de altitude, em locais úmidos e sombreados. Distribui-se na zona da mata e sul de Minas Gerais, nas serras da Mantiqueira e do Caparaó; até o vale do Paraíba paulista na serra da Bocaina, com um registro para a região metropolitana de São Paulo.

Espécie muito semelhante a $A$. bragae, diferindo desta principalmente pelo pecíolo obtuso abaxialmente, sulcado com margens obtusas adaxialmente, na forma obtusa a subcordada na base da lâmina foliar, na forma da nervura coletora que sai da base laminar em linha reta, no comprimento superior do pedúnculo, do estípite e na posição geográfica, e também de $A$. marense K. Krause, diferindo desta, principalmente, pela falta de pontos glandulares em ambas as faces da lâmina foliar, pela forma do pecíolo, sendo sulcado com margens obtusas adaxialmente e obtuso abaxialmente. Caracteriza-se principalmente pela lâmina foliar lanceolada a ovado-lanceolada com a nervura coletora saindo da base laminar em linha reta e o longo estípite. Floresce nos meses de janeiro, junho a setembro e novembro, frutifica no mês de junho.

Até o momento, segundo a lista vermelha das espécies ameaçadas da IUCN (1998), A. lucioi encontra-se Em Perigo (EN), por possuir uma extensão de presença estimada em menos de $5.000 \mathrm{~km}^{2}$, fragmentada, e provavelmente menos de 2.500 indivíduos maduros.

21. Anthurium luschnathianum Kunth, Enum. Pl. 3: 73. 1841. Tipo: BRASIL. RIO DE JANEIRO: 1832, Riedel s.n. (holótipo - LE†) também representado por um desenho a lápis, Icone Schott no. 572 (neótipo - LE!, designado por Coelho, 2007). Fig. 8f-g

Anthurium olfersianum var. luschnathianum (Kunth) Engl. in Mart. Fl. Bras. 3(2): 91. 1878. Tipo: Desenho a lapis de 
um espécime no herbário Geral em Berlin preparado de uma planta cultivada no Jardim Botânico de Berlin, IX.1849: Schott Icone Aroideae No. 571 (neótipo - W!, designado por Coelho, 2007).

Terrestre, raramente rupícola e saxícola; caule decumbente, tornando-se ereto na extremidade; raízes grossas, esverdeadas, 4,5-5,5 mm diâm.; entrenós 0,3-2 cm compr.; catafilos e profilos acastanhados quando secos, esverdeados, acastanhados em material vivo, inteiros, persistentes, levemente decompostos a caducos no ápice e em direção a base do caule, $1,3-11,1 \times 4,2-5,8 \mathrm{~cm}$; bainha $1,2-4,1$ cm compr.; pecíolo esverdeado, obtuso abaxialmente, raramente achatado a sulcado com margens obtusas adaxialmente, 4,8-73,6 cm compr.; genículo levemente mais claro e levemente mais espesso a mais espesso que 0 pecíolo, 0,5-4,45 cm compr.; lâmina foliar esverdeada levemente discolor, amarronzada quando seca, ereta, cartácea em material seco e vivo, não pruinosa abaxialmente, pontos glandulares ausentes, lanceolada a ovada, raramente elíptica, ápice agudo a rostrado, curtamente apiculado, base truncada a cordada, freqüentemente com a parte mais inferior da base curtamente estreitada, seio arqueado a triangular, $17,8-43,3 \times 5,8-23,2 \mathrm{~cm}$; nervura mediana achatada a achatada para a base a aguda para o ápice adaxialmente, obtusa abaxialmente; nervuras basais, geralmente 1, unindo-se a margem da lâmina no 1/3 basal; nervuras secundárias $5-15$ em ambas as faces, levemente proeminentes abaxialmente, levemente impressas a obscuras adaxialmente a obscuras em ambas as faces; nervuras coletoras saindo da base laminar ou um pouco acima dela, 0,4-1,7 cm afastadas da margem, pouco visível adaxialmente; pedúnculo esverdeado, cilíndrico, 31,5-65,4 cm compr.; espata esverdeada, esverdeadoarroxeada, membranácea, lanceolada, formando ângulo agudo com o pedúnculo, 5,2$10,9 \times 0,8-2,4 \mathrm{~cm}$, decorrência $0,4-2,1 \mathrm{~cm}$ compr.; espádice vináceo, arroxeado, acastanhado-purpurescente, acastanhadoarroxeado, acastanhado, cilíndrico, séssil ou curtamente estipitado, 6,2-11,9 cm compr., estípite 2-3 mm compr.; bagas esverdeadas. Material selecionado: BRASIL. RIO DE JANEIRO: Angra dos Reis, 6.II.1996, M. Nadruz et al. 1165 (RB); 6.II.1996, M. Nadruz et al. 1171 (RB). Mangaratiba, 30.IX.1993, fl., V.S. Fonseca et al. 110 (RB). Macaé, 27.VIII.1982, fl., D. Araujo et al. 5243 (GUA). Niterói, 28.I.1999, fl., A. Oliveira et al. 5(FFP); 9.I.2001, fl., A.A.M. Barros et al. 971 (FFP). Rio de Janeiro, 18.I.2003, M. Nadruz et al. 1538 (RB).

Possui hábito terrestre, raramente rupícola e saxícola, sendo esciófila, semi-esciófila até heliófila; presente em locais úmidos a pouco úmidos. Espécie endêmica do estado do Rio de Janeiro, com distribuição nas regiões sul, metropolitana e noroeste fluminense, geralmente em floresta baixa de restinga, raramente em floresta submontana próxima ao mar até $250 \mathrm{~m}$ altitude. Existem registros de floração para o ano todo com exceção dos meses de abril e outubro, frutificando em janeiro, fevereiro, junho e agosto.

Anthurium luschnathianum é reconhecida pela sua robustez, pelos grandes catafilos e profilos inteiros e acastanhados ao longo do caule, pelas lâminas foliares com base truncada a cordada e, geralmente, estreitado-cuneada na extremidade basal. A espécie mais semelhante é A. parasiticum (Vell.) Stellfeld que diferencia-se por apresentar catafilos e profilos geralmente cor-de-palha e levemente decompostos a decompostos ao longo do caule, lâmina foliar com base geralmente obtusa a truncada, não estreitado-cuneada na extremidade basal e com distribuição desde o estado da Bahia até São Paulo, em florestas de baixada, submontana e montana até $860 \mathrm{~m}$ alt., raramente em floresta de restinga. Anthurium luschnathianum compreendia um grupo de variedades de $A$. olfersianum, de difícil entendimento, denominado "complexo olfersianum" (Coelho \& Mayo 2007).

A espécie ocorre em algumas áreas de restinga que atualmente vem sofrendo grande ação antrópica, com extensão de presença estimada menor que $5.000 \mathrm{~km}^{2}$, fragmentada e tamanho da população estimada em menos de 2.500 indivíduos maduros. Desta forma é 
considerada Em Perigo (EN) pelos critérios da IUCN (1998).

22. Anthurium marense K. Krause, Notizbl. Bot. Gart. Berlin-Dahlem 9: 271. 1925. Tipo: BRASIL. SÃO PAULO: na Serra do Mar perto de Campo Grande, 26.IV.1914, A.C. Brade 7189 (holótipo - SP!). $\quad$ Fig. 8h-i, 9a-c

Terrestre, raramente hemiepífita; entrenós 0,2-2,1 cm compr.; catafilos e profilos esverdeados, esverdeado-vináceos, vináceos, acastanhado-rosados, acastanhados, inteiros a levemente decompostos no ápice, acastanhados, inteiros a levemente decompostos, persistentes a caducos para a base do caule, 0,6-4,35 cm compr.; bainha 0,6-1,95 cm compr.; pecíolo esverdeado, esverdeado-vináceo, sendo vináceo a avermelhado na base nas folhas novas, compresso lateralmente, geralmente obtuso, agudo a subcarenado abaxialmente, achatado a levemente sulcado com margens raramente obtusas, geralmente agudas a carenadas adaxialmente, 3,9-27 cm compr.; genículo concolor, mais claro a levemente mais escuro (esverdeado-vináceo em folha jovem) e levemente mais espesso a mais espesso que o pecíolo, 0,3-1,6 cm compr.; lâmina foliar esverdeada discolor, ereta, cartácea em material vivo, membranácea em material seco, com não pruinosa abaxialmente, pontos glandulares em ambas as faces, lanceolada, oblonga, elíptica a subobovada, base raramente aguda, geralmente obtusa, arredondada a truncada, sem a presença de seio, ápice subtruncado, subobtuso-apiculado, agudo curtamente apiculado, curtamente acuminado, 7,2-20,95 × 2,6-9,55 cm; nervura mediana aguda em ambas as faces a subcarenada ou aguda no ápice a obtusa para a base abaxialmente e aguda adaxialmente; nervuras secundárias impressas adaxialmente, proeminentes abaxialmente, 3-8 em ambas as faces; nervura basal raramente 1 , terminando na margem do terço basal da lâmina; nervuras coletoras saindo da base laminar, raramente acima dela, 1,5-9 mm afastadas da margem; pedúnculo esverdeado, vináceo-esverdeado,
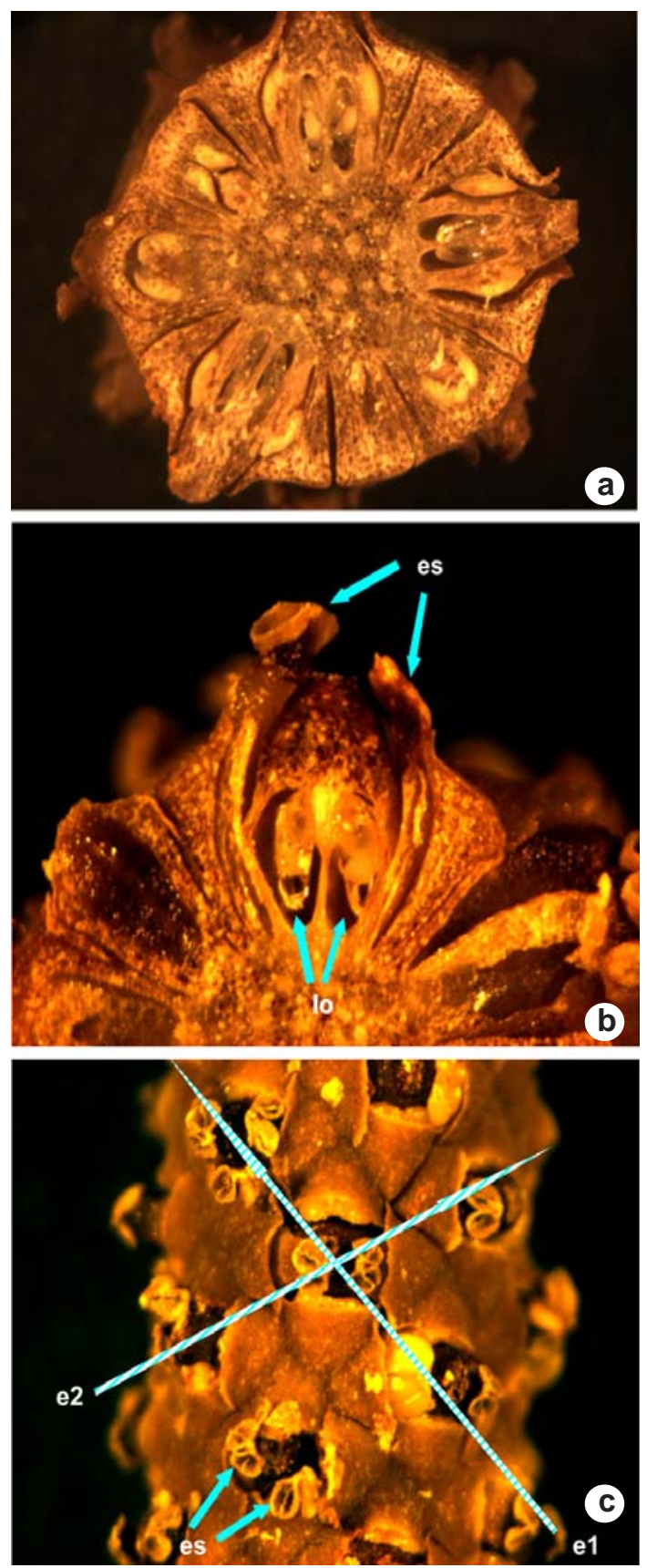

Figura 9-a-c. Anthurium marense - a. detalhe do espádice, em seção transversal; b. detalhe da flor, evidenciando estames excertos (es) e lóculos do ovário (lo); c. detalhe do espádice com os estames (es) excertos, mostrando o arranjo espiralado das flores em espiral principal (e1) e secundária (e2) (Nadruz 1548 cultivado no JBRJ).

Figura 9 - a-c. Anthurium marense - a. detail of the spadix, in transversal section; b. detail of the flower, showing the exserted stamens (es) and ovary locules (lo); c. detail of the spadix with exserted stamens (es), showing the disposition of theflowers in the main (e1) and secondary spirals (e2) (Nadruz 1548 cultivated at the JBRJ). 
rosado a vináceo, cilíndrico, subanguloso a 24 anguloso, 4,8-35,3 cm compr.; espata membranácea, esverdeada, esverdeadorosada, esverdeado-vinácea a vinácea, navicular, ereta ou formando ângulo perpendicular com o espádice, 1,3-6 × 0,3$0,7 \mathrm{~cm}$, lanceolada, formando ângulo reto, obtuso a subagudo com o pedúnculo; espádice estipitado, afunilado, 1-8,4 cm compr., estípite levemente rugoso a liso, 0,7-6,5 cm compr.; bagas esverdeadas.

Material selecionado: BRASIL. PARANÁ: Guaratuba, 5.III.1999, fr., E.P. Santos et al. 770 (UPCB); 22.X.1999, fl., E.P. Santos et al. 819(UPCB). Piraquara, 3.II.1967, fl. e fr., G. Hatschbach 16087 (NY, RB, US). RIO DE JANEIRO: Itatiaia, 21.V.1902, fl., P.K. Dusén 548 (RB). SÃO PAULO: Bertioga, 2.XII.1998, fl., S.E. Martins et al. 353 (USC); 16.IX.1999, fl., S.E. Martins 553 (USC). BiritibaMirim, 4.I.1984, fl., A.C. Filho 2195 (SP). Pindamonhangaba, 20.VIII.1992, fl., S.A. Nicolau et al. 2157 (SP). Salesópolis, 10.I.1985, fl., A.L. Peixoto et al. 3531 (RB); 20.X.2001, fl., J.R. Pirani et al. 4900 (SP). Santo André, 11.III.2003, fl., M. Nadruz et al. 1548 (RB); 11.III.2003, fl., M. Nadruz et al. 1549 (RB). São José do Barreiro, 27.VI.2001, fl. e fr., M. Nadruz et al. 1412 (RB).

Espécie frequentemente terrestre, crescendo em locais sombreados e úmidos, na floresta montana entre 800-1350 m altitude. Anthurium marense, até o momento, era conhecida somente da Serra do Mar do leste paranaense e das regiões metropolitana e vale do Paraíba paulista. Atualmente uma nova ocorrência na região do médio Paraíba, no município de Itatiaia, estado do Rio de Janeiro, foi constatada.

Espécie muito semelhante a A. hoehnei, conforme exposto anteriormente, podendo ser confundida também com $A$. bragae que apresenta pecíolo sulcado com margens obtusas adaxialmente, lâmina foliar sem pontos glandulares nas faces, nervura mediana obtusa em ambas as faces, espata aplanada formando ângulo agudo com o pedúnculo e estípite menor que $0,5 \mathrm{~cm}$ compr., enquanto $A$. marense apresenta pecíolo achatado a sulcado com margens geralmente agudas a carenadas adaxialmente, lâmina foliar com pontos glandulares em ambas as faces, nervura mediana geralmente aguda em ambas as faces, espata navicular formando ângulo obtuso a reto com o pedúnculo e estípite acima de $0,7 \mathrm{~cm}$ compr.

Floresce o ano todo, frutificando nos meses de fevereiro, março e junho.

Por apresentar distribuição geográfica numa extensão menor do que $20.000 \mathrm{~km}^{2} \mathrm{e}$ tamanho da população estimada em menos que 10.000 indivíduos maduros, A. marense foi considerada Vulnerável (VU), baseado nos critérios de IUCN (1998).

23. Anthurium miquelianum C. Koch \& Augustin in Index Sem. Hort. Berol. 1855, appendix: 5. 1856. Tipo: Desenho colorido de uma planta cultivada nos Jardins Imperiais, Palácio de Schönbrunn, Austria. Icone Schott no. 575 (neótipo-W! designado por Coelho, 2007).

Fig. 10a-b

Terrestre; caule ereto, 2,6-3 cm grossura; entrenós $0,4-2 \mathrm{~cm}$; catafilos e profilos inteiros a levemente decompostos, esverdeado-avermelhados, esverdeados a amarelo-esverdeados no ápice, decompostos, cor de palha, acastanhados a caducos para a base do caule, 2,1-9,7×3,7-6 cm, bainha $0,8-$ $5 \mathrm{~cm}$ compr.; pecíolo quando jovem avermelhado tornando-se esverdeado, ereto, obtuso abaxialmente, achatado a levemente sulcado com margens obtusas adaxialmente, 4,9-47,6 × 0,5-0,8 cm; genículo mais espesso, rosado a esverdeado-avermelhado em folha jovem a concolor a levemente mais claro que o pecíolo, 0,7-2,7 cm compr. Folha com lâmina foliar esverdeada discolor, cartácea a fortemente cartácea, não pruinosa abaxialmente, pontos glandulares ausentes, raramente lanceolada a geralmente elíptica, ápice levemente rostrado a agudo-apiculado, base aguda a cuneada, curtamente cuneadoestreitada a obtuso-estreitada, subereta a arcoada, 19,7-45,5 × 7,95-25,6 cm; nervura mediana obtusa em ambas as faces, sendo mais achatada ou achatada no terço basal, tornando-se roliça a levemente aguda para o ápice a raramente aguda adaxialmente; 
nervuras secundárias impressas adaxialmente e proeminentes abaxialmente, 816 pares, terciárias visíveis; nervura coletora saindo da base laminar ou um pouco acima dela, 0,7-2,3 cm afastada da margem. Inflorescência em pós-antese ereta, pedúnculo cilíndrico, levemente anguloso a raramente 1-carenado, avermelhado quando jovem, vináceo, esverdeado-rosado na metade inferior e esverdeado-amarelado na metade superior, esverdeado a acastanhado, 13-62,8 $\times 0,4 \mathrm{~cm}$; espata em pré-antese esverdeada, em pós-antese esverdeada a esverdeadovinácea para o ápice, esverdeada com margem acastanhada, acastanhada, membranácea a cartácea, lanceolada, plana, formando ângulo agudo com o pedúnculo, decorrência 0,5-1,5 cm compr., quase caduca, 5,1-11,5 ×1-2 cm; espádice cilíndrico, séssil, esverdeado, vináceo, acastanhado, 9,7 -11 ×0,4-0,8 cm; bagas não observadas.

Material selecionado: BRASIL. RIO DE JANEIRO: Rio de Janeiro, 25.IV.2001, M. Nadruz et al. 1363 (RB); 25.IV.2001, fl., M. Nadruz et al. 1365 (RB). SÃO PAULO: Cananéia, 6.IX.1994, fl., M.Y. Nakagomi et al. 34 (RB); 18.VII.2002, fl., M. Nadruz et al. 1495 (RB). Peruíbe, 21.V.2002, fl., M. Nadruz et al. 1473 (RB); 22.V.2002, fl., M. Nadruz et al. 1474 (RB).

A espécie possui o hábito terrestre, sendo ombrófila, semi-ombrófila, esciófila e semiesciófila. Espécie com distribuição restrita a somente três localidades, ocorrendo nas regiões do litoral norte paulista e metropolitana do Rio de Janeiro, estendendo-se desde as florestas baixas até montana.

Anthurium miquelianum é pouco frequente na floresta atlântica. É reconhecida, principalmente, pelo porte robusto, pela lâmina foliar geralmente elíptica com a base aguda a estreitada e pelas nervuras secundárias proeminentes abaxialmente e impressas adaxialmente. Confunde-se com $A$. parasiticum, porém diferenciando-se por este apresentar porte delicado, lâmina foliar geralmente lanceolada com a base obtusa a truncada e nervuras secundárias levemente proeminentes abaxialmente e pouco impressas adaxialmente.
Floresce nos meses de abril, maio, julho e setembro, porém sem informações sobre período de frutificação.

Coelho \& Mayo (2007) posicionaram, equivocadamente, A. miquelianum como sinônimo de $A$. parasiticum. Os autores basearam-se nos comentários de Koch \& Augustin (1855) e Engler (1905) sobre a possiblidade de a espécie ser muito semelhante a A. parasiticum. Com observações nos materiais tipo mais detalhadas, notou-se características sutis que sustentam a separação dos indivíduos em espécies distintas.

24. Anthurium mourae ("mourai") Engl., Engler in Bot. Jahrb. Syst. 25: 416 1898. Tipo: BRASIL. MINAS GERAIS: Caparaó, s.d., J.T. de Moura 942 (holótipo - B!). Fig. 10c

Geralmentente terrestre, rupícola, raramente hemiepífita; caule ereto; entrenós 0,4-4,2 cm compr.; catafilos e profilos acastanhos em material seco, acastanhados em material vivo, inteiros no ápice, inteiros a levemente decompostos, persistentes para a base do caule, $1,3-5,3 \times 2,7 \mathrm{~cm}$; bainha $0,4-$ 2,4 cm compr.; pecíolo esverdeado, cilíndrico, obtuso abaxialmente e levemente achatado a levemente sulcado com margens obtusas a subagudas adaxialmente, 3,8-14,7 cm compr.; genículo obtuso a levemente sulcado adaxialmente, mais espesso, levemente mais escuro a levemente mais claro que o pecíolo, 2-8 mm compr.; lâmina foliar esverdeada discolor, brilhante na face superior, subdeflexa, cartácea em material vivo e seco, não pruinosa abaxialmente, pontos glandulares ausentes, estreitada em direção ao ápice, lanceolada a raramente subovada, base raramente subaguda, geralmente obtusa, truncada a subcordada, ápice agudo a rostrado, apiculado, 5,3-18,2×1,3-5,1 cm, extremidade da margem laminar revoluta; nervura mediana roliça abaxialmente, aguda adaxialmente; nervuras secundárias impressas adaxialmente, levemente proeminentes abaxialmente, 5-8 em ambas as faces e terciárias evidentes em ambas as faces da lâmina; nervuras coletoras saindo da base laminar 1,5-6 mm afastadas da 

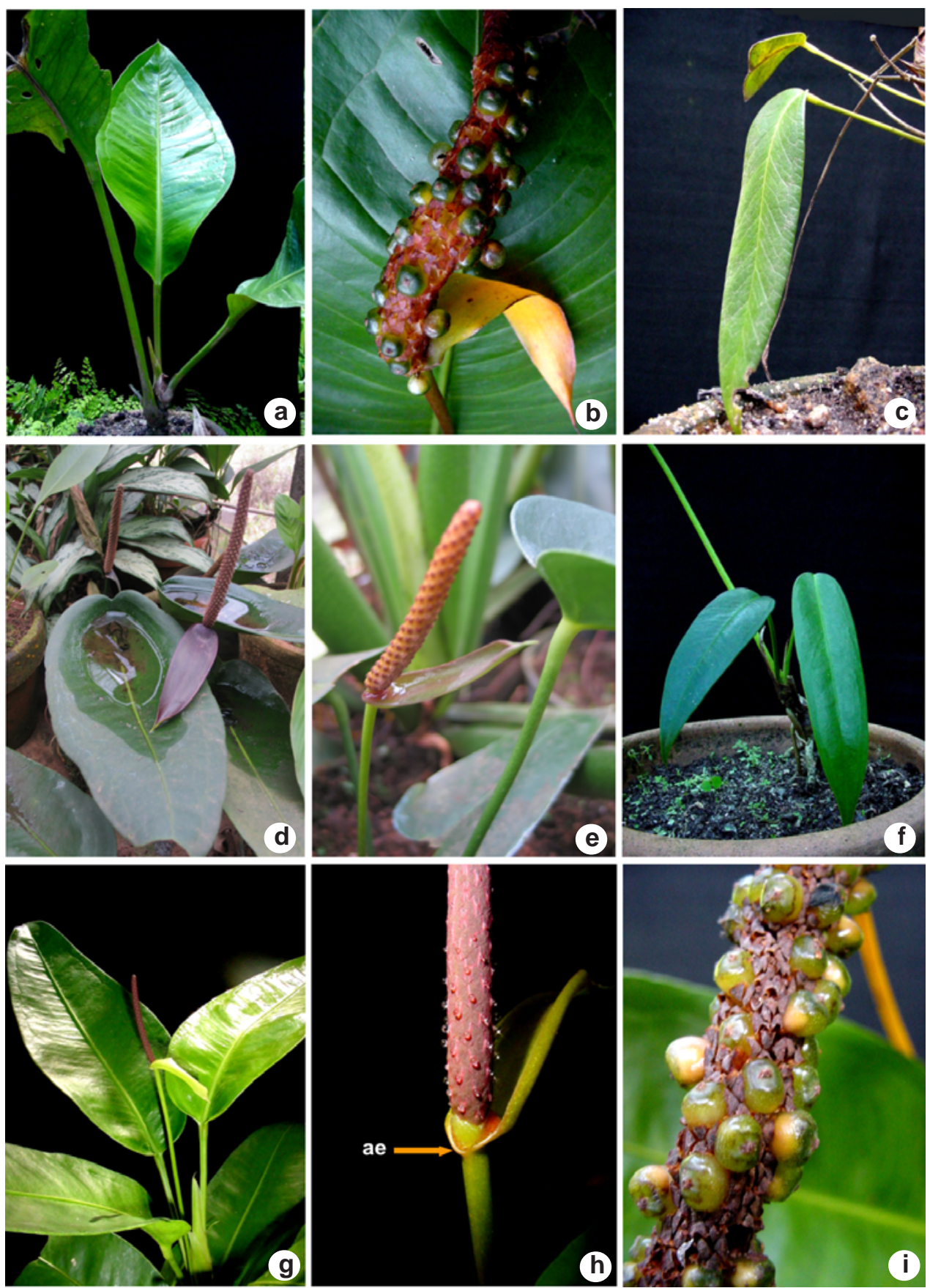

Figura 10 - a-b. Anthurium miquelianum - a. hábito (Nadruz 1473 cultivado no JBRJ); b. detalhe da infrutescência madura (Nadruz 1473 cultivado no JBRJ). c. A. mourae - c. folha deflexa (Nadruz 1478 cultivado no JBRJ). d-e. A. navicularis d. lâmina foliar; e. inflorescência (Catharino 1406 cultivado no Instituto de Botânica, SP). f. A. organense - f. hábito (Nadruz 1544 cultivado no JBRJ). g-i. A. parasiticum - g. hábito (Nadruz 1462 cultivado no JBRJ); h. detalhe da inflorescência, mostrando o ângulo obtuso da espata (ae) com o pedúnculo e o espádice (Nadruz 1355 cultivado no JBRJ); i. detalhe da infrutescência (Nadruz 1353 cultivado no JBRJ).

Figura 10 - a-b. Anthurium miquelianum - a. habit (Nadruz 1473 cultivated at the JBRJ); b. mature infrutescence, detail (Nadruz 1473 cultivated at the JBRJ). c. A. mourae - c. deflected leaf (Nadruz 1478 cultivated at the JBRJ). d-e. A. navicularis - d. leaf blade; e. inflorescence (Catharino 1406 cultivated at Botanical Institute of São Paulo). f. A. organense - f. habit (Nadruz 1544 cultivated at the JBRJ). g-i. A. parasiticum - g. habit (Nadruz 1462 cultivated at the JBRJ); h. detail of the inflorescence, showing the obtuse angle between spathe (ae) with the peduncle and the spadix (Nadruz 1355 cultivated at the JBRJ); i. detail of the infrutescence (Nadruz 1353 cultivated at the JBRJ). 
margem; pedúnculo cilíndrico, esverdeadorosado a esverdeado-vináceo, 5,6-24,1 cm compr.; espata esverdeada a esverdeadovinácea, avermelhado-amarronzada, membranácea, lanceolada, navicular, 1,5-4,1 × 0,55-1 cm, formando ângulo obtuso a reto com o pedúnculo; espádice longamente estipitado, vináceo, avermelhado-acastanhado a acastanhado, 1,15-3,8 cm compr., estípite 0,8-6,6 cm compr.; bagas imaturas com ápice esverdeado.

Material selecionado: BRASIL. MINAS GERAIS: Alto Caparaó, VIII.1997, L. Leoni 3739 (GFJP); 18.VI.2002, fl. e fr., M. Nadruz et al. 1478 (RB). Mariana, fl., G. Eiten 7056 (US).

A espécie ocorre próximo a rios, em locais úmidos, sombreados a pouco ensolarados, como terrestre, rupícola e, mais raramente, hemiepífita. Espécie endêmica das florestas de altitude do estado de Minas Gerais, sendo considerada uma das espécies de ocorrênica em maior altitude na subseção Flavescentiviridia, cerca de 1930 m no Parque Nacional do Caparaó. Os espécimes de C. Schwacke 14626 e 14706, citadas por Gonçalves \& Salviani (2001), como pertencentes à $A$. mourae, trata-se na verdade de A. parvum N.E. Br., que difere da primeira pelo caule curto, geralmente pela presença de nervuras basais na lâmina foliar, coloração vinácea da espata e estípite até $1 \mathrm{~cm}$ compr., contra caule longo, sem nervuras basais, coloração geralmente esverdeada da espata e estípite até cerca de $6 \mathrm{~cm}$ compr. Anthurium mourae pode ser reconhecida pela aparência delicada e, principalmente, pela presença de um longo estípite, frequentemente mais longo que o espádice. A espécie pode ser encontrada geralmente crescendo sobre touceiras de bromélias, penetrando as raízes nos tanques formados pela base das folhas dessas espécies (Gonçalves \& Salviani 2001). Até o momento os meses registrados para floração são abril, junho e outubro, com frutificação em abril e outubro.

Por possuir uma extensão de presença estimada em menos de $100 \mathrm{~km}^{2}$ com tamanho da população estimada em menos de 250 indivíduos maduros, A. mourae é considerada Criticamente em Perigo (CR), pelos critérios da IUCN (1998).
25. Anthurium navicularis Catharino \& Nadruz, Rodriguesia 59(4): 829-833. 2008. Tipo: BRASIL. SÃO PAULO: Peruíbe, Estação Ecológica Juréia-Itatins. Proximidades do maciço da Juréia, mata de encosta junto ao paredão rochoso próximo ao alojamento, 17.V.1990, E.L.M. Catharino, I. Cordeiro \& L. Rossi 1406 (holótipo - SP!, isótipo - RB!).

Fig. 10d-e

Caule robusto, ereto; entrenós curtos; profilos e catafilos levemente decompostos no ápice e para a base do caule, amarronzados, ca. 0,7 cm compr.; pecíolo esverdeado, roliço, quando jovem apresentando pequenas pontuações mais claras, ereto a semiereto, 10 $23 \times 0,3-0,6 \mathrm{~cm}$; genículo intumescido e mais claro que o pecíolo, $1-2,5 \times 0,5-0,8 \mathrm{~cm}$; lâmina foliar coriácea, não pruinosa abaxialmente, pontos glandulares ausentes, ovada, esverdeada, levemente discolor, perpendicular, ápice agudo a rostrado com apículo curto ca. $0,2 \mathrm{~cm}$ compr., base curtamente cordada em lâmina jovem, tornando-se emarginada a subtruncada pela junção dos lobos posteriores, conseqüentemente peltada com formato navicular, $15,5-50 \times 5,2-13 \mathrm{~cm}$; nervura primária arredondada em ambas as faces; nervuras secundárias $10-12$, pouco visíveis em ambas as faces; nervuras coletoras saindo da base laminar ca. $45^{\circ}$ da nervura central, $0,7-1,4 \mathrm{~cm}$ afastada da margem; nervuras basais três, a mais externa terminando na base do lobo posterior da lâmina, a mediana terminando no terço inferior próximo ao lobo posterior da lâmina foliar, a mais interna terminando na parte mais alta do terço inferior, raramente no ápice da lâmina formando uma segunda nervura coletora com $0,2-0,3 \mathrm{~cm}$ afastada da margem; pedúnculo cilíndrico, esverdeado, ereto, 14-33 cm compr.; espata cartácea, lanceolada, apiculada, vinácea adaxialmente, esverdeada a esverdeadovinácea abaxialmente, plana, geralmente subdeflexa, formando ângulo obtuso com o pedúnculo em pré-antese, ca. 11,9 × 3,2 cm; espádice cilíndrico, esverdeado a acastanhado, séssil a curtamente estipitado, 5,6-14 × 0,6- 
1,1 cm, estípite 0,2-0,6 cm compr.; flores 5 na espiral primária e 9 na secundária, tépalas cuculadas, as anteriores/posteriores côncavas ventralmente e subcarenadas dorsalmente, as laterais levemente côncavas ventralmente e subcarenadas dorsalmente, 0,19-0,2 × 0,16$0,21 \mathrm{~cm}$, estames opostos as tépalas posteriores/anteriores, com filetes levemente intumescidos do meio para a base, estames opostos às tépalas laterais com filetes achatados não intumescidos, anteras dorsifixas com tecas geralmente ovadas a oblíquas, 0,22 $0,25 \times 0,11-0,12 \mathrm{~cm}$, pólen não observado, gineceu oblongo, séssil, estigma levemente proeminente e obtuso, ovário bilocular, 1 óvulo por lóculo com placentação axilar subapical e tricomas nos funículos, ca. 0,22 × 0,14-0,16 $\mathrm{cm}$; bagas maduras vináceas.

Material Selecionado: BRASIL. SÃO PAULO: Iguape, Estação Ecológica Juréia-Itatins, Serra da Juréia, caminho do Imperador, 19.VI.1990, I. Cordeiro, L. Rossi \& M.C.H. Mamede 660 (parátipo - SP!).

Erva predominantemente rupícola em paredões rochosos, higrófila e heliófila.

Pertence à subseção Flavescentiridia devido a presença de caule e entrenós curtos, lâmina foliar cartácea, com base obtusa, discolor, nervuras secundárias numerosas, visíveis e mais proeminentes do que as terciárias, com ocorrência no Sudeste do Brasil. Pode ser confundida com A. jureianum, diferindo desta por apresentar lâminas foliares mais coriáceas e naviculares, hábito e inflorescências mais robustas. Apesar de não terem sido realizadas maiores observações, o formato navicular da lâmina foliar sugere que a mesma possa servir como um reservatório de água para vários organismos, tendo em vista o habitat temporariamente seco da área de ocorrência, apesar de ser uma região chuvosa.

A Estação Ecológica Juréia-Itatins localiza-se no município de Iguape, litoral sul de São Paulo, constituindo uma das regiões mais protegidas e ímpares do litoral paulista. O maciço granítico da Juréia está separado do maciço de Itatins por planícies quaternárias recentes, localizando-se nos limites da orla marítima, apresentando costões rochosos marítimos e pequenas bacias sedimentares "alveolares" relacionadas com as planícies sedimentares do entorno. A localização deste maciço cristalino costeiro, associada com a história geológica, leva a considerações sobre a existência de uma "paleo-ilha", associada a níveis do mar mais altos ou em períodos anteriores à deposição da extensa planície quaternária entre este maciço e o maciço de Itatins, mais interior (Catharino \& Olaio 1990).

A situação insular da localidade de ocorrência $A$. navicularis, leva à possível hipótese de sua evolução por isolamento geográfico, a partir de colonização pretérita por espécies de distribuição mais ampla.

Devido a sua ocorrência muito restrita e à populações pequenas, estimadas em menos de 1.000 indivíduos maduros, além das incertezas sobre a efetiva conservação da importante área natural em que ocorre, pode ser considerada Vulnerável (VU) pelos critérios IUCN (1998).

26. Anthurium organense Engl., Engler in Bot. Jahrb. Syst. 25: 415. 1898. Tipo: BRASIL. RIO DE JANEIRO: Serra dos Orgãos, Campos das Centas (“Antas”), II.1887, H. Schenck 2873 (holótipo - B!).

Fig. 10f

Terrestre, ocasionalmente rupícola e epífita; caule ereto; entrenós 3-5 mm compr.; catafilos e profilos esverdeado-amarelados, acastanhados a raramente cor-de-palha em material seco, esverdeados, esverdeadocreme, esverdeado-amarelados, acastanhados, cor-de-palha em material vivo, inteiros a decompostos no ápice, decompostos a caducos para a base do caule, $0,8-5,95 \mathrm{X} 1,6-1,8 \mathrm{~cm}$ na base; bainha $0,5-3,15 \mathrm{~cm}$ compr.; pecíolo esverdeado, esverdeado sendo avermelhados para a base, esverdeados com manchas escuras, acastanhado-cinéreos, cilíndrico a geralmente levemente achatado, achatado a raramente sulcado com margens geralmente obtusas a agudas adaxialmente, obtuso abaxialmente, 2,15-42 cm compr.; genículo concolor, levemente mais claro a levemente mais escuro e mais espesso que o pecíolo, $0,2-$ 
3,4 cm compr.; lâmina foliar esverdeada discolor a levemente discolor, ereta a perpendicular com o pecíolo, membranácea a cartácea em material seco, membranácea, subcartácea a cartácea em material vivo, não pruinosa abaxialmente, pontos glandulares ausentes, lanceolada a linear-lanceolada, raramente sub-ovada, base frequentemente obtusa e subaguda, raramente truncada a levemente emarginada e ápice rostrado, rostrado-apiculado, agudo-apiculado, obtusoacuminado, 4,3-33,5 ×1,1-7,75 cm; nervura mediana aguda a obtusa adaxialmente, obtusa abaxialmente; nervuras secundárias obscuras a levemente impressas adaxialmente, pouco distintas abaxialmente a obscuras em ambos as faces, 5-17 em ambas as faces; nervuras coletoras saindo da base laminar ou raramente um pouco acima dela, $0,1-1,1 \mathrm{~cm}$ afastadas da margem; pedúnculo cilíndrico, esverdeado as vezes esverdeado-avermelhado na base, esverdeado-avermelhado, rosado, avermelhado, esverdeado-acastanhado, 6-42,1 cm compr.; espata membranácea, esverdeada, esverdeado-avermelhada, avermelhada, esverdeado-vinácea, acastanhado-avermelhada, acastanhado-esverdeada, esverdeadoamarronzada, lanceolada a linear-lanceolada, sub-navicular, 1,16-5,25×0,4-0,7 cm, formando ângulo frequentemente agudo, raramente obtuso a reto com o pedúnculo, decorrência $2-6 \mathrm{~mm}$ compr.; espádice esverdeado, purpurescente, vináceo, arroxeado, acastanhado-esverdeado, acastanhado quando envelhecido, cilíndrico, 1,85-6,15 cm compr., raramente séssil a geralmente estipitado, estípite $0,1-1,6 \mathrm{~cm}$ compr.; bagas não observadas.

Material selecionado: BRASIL. ESPÍRITO SANTO: Fundão, 25.VII.2000, fl., V. Demuner et al. 1235 (MBML). Santa Teresa, 12.VII.2001, fl., L. Kollmann 4176 (MBML). RIO DE JANEIRO: Macaé, 14.VIII.2001, fl., M. Bovini et al. 2081 (RB). Nova Friburgo, 1.V.2001, fl., M. Nadruz et al. 1382 (RB). Parati, 12.II.2003, M. Nadruz et al. 1542 (RB). Petrópolis, 28.VIII.2002, M. Nadruz et al. 1507 (RB). Santa Maria Madalena, 28.VI.1989, fl., G. Martinelli et al. 13364 (RB); 15.V.2007, fl., G. Heiden et al. 741 (RB). Teresópolis, 24.IV.1966, fl., J.L. Sobrinho 1642 (GUA); 21.III.2007, fl., M. Nadruz et al. 1773 (RB).
Possui o hábito terrestre e rupícola, as vezes epífita, crescendo em locais úmidos e sombreados. Até o presente estudo $A$. organense era conhecida somente da região serrana do estado do Rio de Janeiro, atualmente tem sua distribuição nas florestas litorâneas da região sul, mais precisamente no município de Parati, nas florestas montanas da região noroeste do Rio de Janeiro e na região central do Espírito Santo. Normalmente é encontrada nas florestas montana e de altitude entre $800-2.000 \mathrm{~m}$, porém o registro para o município de Parati é de 80 a $500 \mathrm{~m}$ alt.

Engler $(1898,1905)$ ao citar o material C. Schenck 2873, cita como local de coleta “Campo das Centas", mas na verdade o nome mencionado na etiqueta do material de C. Schenck é “Campo das Antas”, localidade próxima a Pedra do Assú no município de Petrópolis, Rio de Janeiro. Aespécie é caracterizada principalmente pelo caule curto, pelas folhas suberetas, forma da lâmina foliar lanceolada com a base frequentemente obtusa a truncada e pela presença de estípite que pode chegar a $1,5 \mathrm{~cm}$ compr. A. organense é semelhante a A. longicuspidatum, porém diferencia-se pela presença de caule com entrenós até $0,5 \mathrm{~cm}$ compr., nervuras secundárias pouco visíveis a obscuras e presença de estípite, enquanto $A$. longicuspidatum apresenta caule com entrenós até $1,5 \mathrm{~cm}$ compr., nervuras secundárias impressas a levemente impressas adaxialmente e proeminentes a levemente proeminentes abaxialmente, sem apresença de estípite, com ocorrência nos estados de São Paulo e Rio de Janeiro (com uma única ocorrência).

A floração ocorre nos meses de janeiro, fevereiro, abril a outubro e dezembro. Frutificando, até o momento, somente no mês de dezembro.

27. Anthurium parasiticum (Vell.) Stellfeld, Arqu. Mus. Paranaense 8: 175. 1950. Tipo: Pothos parasitica Vell., Fl. Flumin. Icon. 9: t. 121. 1831. Tipo: Estampa publicada por J.M.C. Vellozo, Flora Fluminensis 9: t. 121. 1831 (lectótipo! designado por Coelho, 2007). BRASIL. RIO DE JANEIRO: Rio de Janeiro, 
Parque Nacional da Tijuca, picada para o morro Cochrane, mata atlântica de encosta pertubada, 24.IV.2002, M.Nadruz \& C.Oliveira 1466 (epitipo - RB! Designado por Coelho, 2007).

Fig. 10g-i

A. olfersianum Kunth, Enum. Pl. 3: 72. 1841. Tipo: Desenho colorido de uma planta cultivada nos Jardins Imperiais, Palácio de Schöenbrunn, Austria. Icone Schott no. 581 (neótipo-W! designado por Coelho, 2007).

[A. oblongatum Schott, nom. illeg.]

A. insculptum Engl. Bot. Jahrb. Syst. 25: 413. 1898. Tipo: Brasil, Rio de Janeiro, s.d. A. Glaziou 9034 (lectótipo- B! designado por Coelho, 2007).

A. saxosum K. Krause, Notizbl. Bot. Gart. Berlin-Dahlem 11: 609. 1932. Tipo: Brasil, perto do Rio de Janeiro sobre rochas em floresta primária. 300-400 m altitude, I.1912, G. Peckolt 39 (B -holótipo!).

Terrestre ou rupícola, raramente saxícola ou hemiepífita; caule ereto; entrenós $0,25-3$ cm compr.; catafilos e profilos quando novos esverdeados, esverdeados com margens rosadas, levemente rosados, esverdeadoamarelados, tornando-se acastanhadoesverdeados, acastanhados a cor-de-palha, inteiros, a raramente decompostos no ápice, cor-de-palha, levemente decompostos a decompostos para a base do caule, geralmente persistentes a raramente caducos, 0,5-9,9 $\times$ $1,4-4,9 \mathrm{~cm}$ na base; bainha $0,7-4,7 \mathrm{~cm}$ compr.; pecíolo esverdeado-vináceo e raramente achatado com margens subcarenadas quando jovem, tornando-se esverdeado, obtuso abaxialmente, subobtuso a achatado, achatado a levemente sulcado do meio para a base, levemente sulcado a sulcado adaxialmente com margens obtusas a raramente agudas, raro levemente compresso, as vezes levemente sulcado lateralmente, 2,2-47,3 × 0,2-0,4 cm; genículo rosado, esverdeado-rosado a esverdeado-vináceo em folha nova, levemente mais espesso a mais espesso, levemente mais claro, mais claro a concolor, levemente mais escuro a mais escuro que o pecíolo, 0,3-2,9 cm compr.; lâmina foliar esverdeada discolor, ereta, subcartácea quando seca, membranácea a cartácea em material vivo, não pruinosa abaxialmente, pontos glandulares ausentes, raramente linear-lanceolada a oblonga, geralmente lanceolada a elíptica, base geralmente truncada, obtusa, curtamente estreitada a raramente aguda a curtamente cuneada, ápice obtuso, obtuso-acuminado, agudo, agudo-apiculado a rostrado, geralmente igualmente estreitada para ambas as extremidades a raro levemente mais estreitada em direção ao ápice, 12,9-63,2 × 3-25,7 cm; nervura mediana obtusa, obtusa sendo aguda próximo a base abaxialmente, aguda a obtusa próximo ao ápice, subaguda, obtusa a achatada do meio para a base a levemente achatada na extremidade basal adaxialmente, vinácea em folha jovem, nervuras secundárias 7-18 em ambas as faces, geralmente pouco impressas na face adaxial e levemente proeminentes na abaxial a obscuras em ambas as faces; nervuras coletoras saindo da base laminar ou um pouco acima dela, 0,2-1,9 cm afastadas da margem; pedúnculo cilíndrico a raro levemente achatado, raramente subanguloso, amarelado, esverdeado-amarelado, esverdeado, esverdeado-vináceo, acastanhado, 9-47,5 × $0,15-0,3 \mathrm{~cm}$; espata esverdeada, esverdeada com margens levemente avermelhadas, esverdeado-rosada, esverdeada com nuança vinácea, esverdeada com nuança acastanhado, esverdeado-acastanhada, rosada, avermelhada, vinácea a arroxeada, vinácea-alaranjada, amarelada a acastanhada quando passada, membranácea, linearlanceolada, lanceolada a oblonga, formando ângulo raramente reto, geralmente obtuso a agudo com o pedúnculo, 2,8-10,9 × 0,45-1,5 cm, decorrência 0,15-1,2 cm compr.; espádice esverdeado, rosado, avermelhado, vináceo, arroxeado, esverdeado-acastanhado, acastanhado, acastanhado-arroxeado, séssil a curtamente estipitado, 3,6-13,8 cm compr., estípite 1-3,5 mm compr.; bagas esverdeadas no ápice, esverdeado-amareladas, hialinas a acastanhadas na base, raramente vináceo no ápice e esverdeado para a base. 
Material selecionado: BRASIL. Cultivado no Hortus Berolinensis, 1855, fl., M. Lindblad s.n. (UPS). BAHIA: Mucuri, 14.IX.1978, fl., S. Mori et al. 10523 (RB). Una, 23.VII.1996, fl., J. Jardim et al. 861 (CEPEC). ESPÍRITO SANTO: Castelo, 12.X.2000, fl., L. Kollmann et al. 3167 (MBML). Guarapari, 26.VII.1990, fl., O.J. Pereira 2153 (GUA); V.2000, fl., A.M. Assis 813 (RB). Linhares, 6.VIII.1983, fl., G. Hatschbach 46771 (MBM). Presidente Kennedy, 18.V.1994, fl., C. Farney et al. 3366 (RB). Santa Leopoldina, 15.VIII.2000, fl., L. Kollmann 376 (MBML). Vila Velha, 20.VII.1973, fl., D. Araújo et al. 364 (RB). MINAS GERAIS: Teófilo Otoni, 14.VIII.1965, fl., R.P. Belém 1617 (RB). RIO DE JANEIRO: Carapebus, 11.VII.2001, fl., M. Nadruz et al. 1428(RB). Guapimirim, 7.VI.1995, fl., J.M.A. Braga et al. 2453 (RUSU); 20.XII.1995, fr., S. Neto et al. 144 (RUSU). Itaipuaçu, 25.XI.1981, fl., R. Andreata 206 (RB, RUSU). Macaé, 15.V.1993, fl., R. Mello-Silva et al. 863 (MO); 26.IV.2001, fl. e fr., D. Araújo s.n. (RB). Magé, 8.XI.1984, fl., G. Martinelli et al.10297 (RB); 30.IV.2002, fl., J. Silva s.n. (RB). Mangaratiba, 16.III.2001, fl., M. Nadruz et al.1353(RB); 17.III.2001, fl., M. Nadruz et al. 1355 (RB). Mendes, 02.V.1993, fl., T. Konno et al. 156 (RUSU). Niterói, 16.VI.2000, fl. e fr., W.B. Carvalho et al. 55 (FFP). Rio Bonito, 22.XI.1975, fl., P.S.H. Laclette 42 (R). Rio de Janeiro, 25.IV.2002, M. Nadruz et al. 1470 (RB); 29.I.2000, fl., J.M.A. Braga 5771 (RB). Inoã, 23.VII.1961, fl., Gomes et al.1218(RB). Silva Jardim, 10.I.1993, fl., S. Pessoa et al. 648 (RB). SÃO PAULO: Birigui, 1990, fl., J.C. Macedo 2962 (ESA). Itanhaém, 11-12.IV.1996, fl., V.C. Souza et al. 11091 (HRCB); 07-08.IX.1996, fr., G.O. Joaquim et al. 33 (ESA). São Paulo, 27.VII.1998, fl., M. Groppo 328 (SP). São Sebastião, 20.IX.1994, fl. e fr., L.E. Catharino et al. 2009A (SP).

Possui o hábito geralmente terrestre, ocorrendo também como rupícola e, mais raramente, saxícola, sendo ombrófila, semiombrófila, esciófila, semi-esciófila e, as vezes, heliófila. Espécie com ampla distribuição, ocorrendo do sul da Bahia até São Paulo, passando pelos estados de Rio de Janeiro e Espírito Santo, estendendo-se desde as florestas baixas, incluindo floresta de restinga (10 m altitude) até montana (860 m altitude). Floresce o ano todo, frutificando em janeiro, abril, junho, novembro e dezembro.

Anthurium parasiticum é muito frequente na floresta atlântica, na maioria dos tipos vegetacionais. É reconhecida, principalmente, pelos catafilos e profilos geralmente inteiros no ápice e levemente decompostos e cor-depalha para a base do caule, pela lâmina foliar geralmente elíptico-lanceolada a lanceolada com a base obtusa a truncada e pelo pecíolo obtuso abaxialmente e sulcado com margens obtusas adaxialmente. Confunde-se com $A$. intermedium, porém diferenciando-se por este apresentar, catafilos e profilos geralmente não persistentes em direção a base do caule, lâmina foliar lanceolada com a base aguda a longamente cuneada, pecíolo obtuso a carenado abaxialmente e achatado com margens carenadas adaxialmente. Uma reorganização taxonômica é apresentada em Coelho \& Mayo (2007) em relação ao "complexo olfersianum", constituído por cinco variedades, de acordo com Engler (1905).

28. Anthurium parvum N.E. Br., in Gard. Chron. 14: 588. 1880. Tipo: BRASIL. perto do Rio de Janeiro, 1878-1879, A. Glaziou 11639 (holótipo - K!).

Fig. 11a-c Anthurium brevilobum N.E. Br., in Gard.Chron. ser. 3, 1: 380. 1887. Tipo: Exsicata de uma planta enviada ao Jardim Botânico Real de Kew, do Jardim Botânico College Trinity, Dublin, XII.1882 por Mr F.W. Burbidge s.n. (síntipo - K!), N.E. Brown s.n. (lectótipo - K! desiginado por Coelho, 2007).

A. mendonçai Engl., in Bot. Jahrb. Syst. 25: 416. 1898. Tipo: Brasil, Rio de Janeiro, próximo a Nova Friburgo, V.1884, Mendonça 1103 (holótipo - B!).

A. nanospadix Engl., in Engler, Pflanzenr. 21: 173, fig. 47. 1905. Tipo: Brasil, Rio de Janeiro, Serra dos Órgãos, em floresta alta, 1900 m, XII.1896, E.Ule 4151 (holótipo - B! isótipo - R!).

A. theresiopolitanum Engl., in Bot. Jahrb. Syst. 25: 415. 1898. Tipo: Brazil, Serra dos Órgãos, Teresópolis, sobre rochas, na floresta, 22.II.1887, H. Schenck 2604 (lectótipo - B! designado por Coelho, 2007).

Terrestre, raramente rupícola, hemiepífita; caule ereto; entrenós 0,1-1,6 cm compr.; catafilos e profilos avermelhados quando novos, acastanhados em material vivo e seco, 
inteiros, levemente decompostos a decompostos no ápice, levemente decompostos, decompostos, persistentes a caducos para a base do caule, $1,2-5,1 \times 1,6 \mathrm{~cm}$; bainha $0,4-2,2 \mathrm{~cm}$ compr.; pecíolo cilíndrico a obtuso abaxialmente, achatado a levemente sulcado com margens obtusas adaxialmente, esverdeado-vináceo a avermelhado quando jovem, esverdeado, esverdeado-vináceo, vináceo, avermelhado- acastanhado, 14-42,7 cm compr.; genículo mais claro a concolor e raro levemente mais escuro e mais espesso que o pecíolo, 0,4-3,2 cm compr.; lâmina foliar esverdeada discolor a levemente discolor, subdeflexa a raramente deflexa, membranácea a subcartácea em material vivo, membranácea, raramente subcartácea em material seco, não pruinosa abaxialmente, pontos glandulares ausentes,
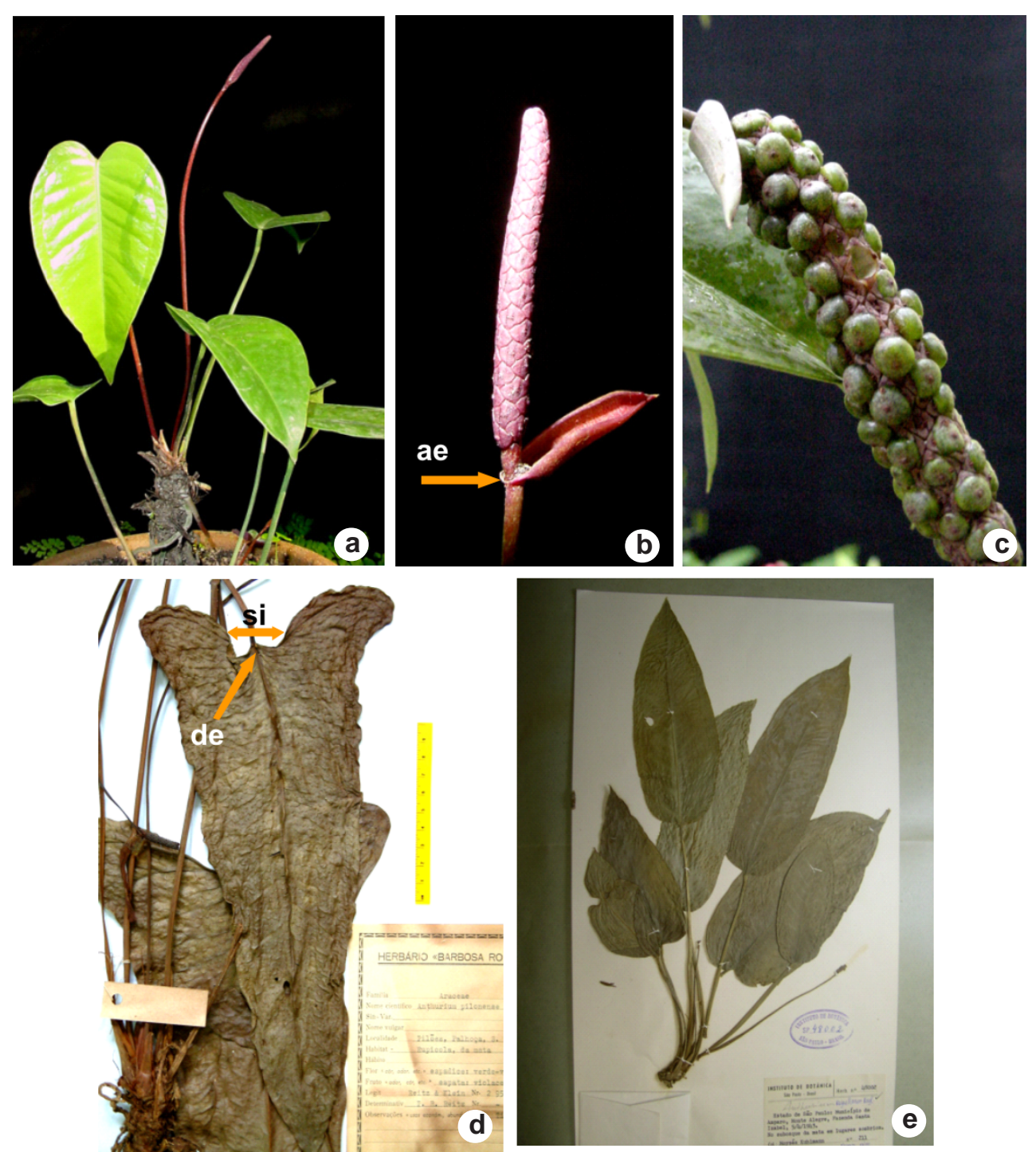

Figura 11 - a-c. Anthurium parvum - a. hábito; b. inflorescência mostrando o ângulo reto (ae) formado pela base da espata em relação ao pedúnculo; c. infrutescência (Nadruz 1504 cultivado no JBRJ). d. A. pilonense - d. lâmina foliar, com pequena decorrência (de) na base e sino arcoado (si) (Reitz 2955). e. A. regnellianum - e. hábito (Kuhlmann 211).

Figura 11 - a-c. Anthurium parvum - a. habit; b. inflorescence showing the right angle (ae) between the base of the spathe and the peduncle; c. infrutescence (Nadruz 1504 cultivated at the JBRJ). d. A. pilonense - d. leaf blade, with small deccurence (de) on the base and the curved sinus (si) (Reitz 2955). e. A. regnellianum - e. habit (Kuhlmann 211). 
ovada, ápice agudo-acuminado, rostrado, apiculado, base raramente subaguda, geralmente arredondada, truncada a cordada, lobos posteriores quando presentes arredondados, seio arqueado, triangular, 9,124,1 $\times 3,7-14,1 \mathrm{~cm}$; nervura mediana aguda adaxialmente, obtusa abaxialmente; nervuras basais $0-1$ a raramente 2 saindo da base laminar, a mais externa terminando na parte inferior dos lobos posteriores, a mais interna arcoada, terminando na margem do terço inferior da lâmina; nervuras secundárias impressas adaxialmente, proeminentes abaxialmente a pouco visíveis, 3-9 em ambas as faces e terciárias obscuras em ambas as faces da lâmina; nervuras coletoras saindo da base laminar, 0,3-1,5 cm afastadas da margem; pedúnculo esverdeado-vináceo, avermelhado, vináceo, avermelhado-acastanhado, cilíndrico, 7-38 cm compr.; espata membranácea, lanceolada a linear-lanceolada, esverdeada, esverdeada com margem vinácea, esverdeadovinácea, esverdeado-acastanhada, avermelhadoacastanhada, avermelhada, vinácea, purpurescenteacastanhado, aplanada, 1-5,5 × 0,2-1 cm, formando ângulo subagudo, obtuso a reto com o pedúnculo, decorrência 1,5-2 mm compr., espádice avermelhado, vináceo, arroxeado, acastanhado-vináceo, purpurescenteacastanhado, acastanhado, estipitado, 1-9,3 cm compr., estípite 0,15-1,1 cm compr.; bagas imaturas esverdeadas com o ápice esverdeadovináceo, maduras esverdeadas e passadas nigrescentes no ápice, esverdeadas para a base. Material selecionado: BRASIL. MINAS GERAIS: Ouro Preto, 24.VI.1902, fl., C. Schwacke 14706 (RB); 30.V.1902, fl., C. Schwake 14626 (RB). RIO DE JANEIRO: 1880, A. Glaziou 11639 (G); II.1888, fl., C. Schwacke 6029 (RB). Nova Friburgo, 4.VI.1993, fl., C. Vieira et al. 254 (RB); 1.V.2001, fl., M. Nadruz et al. 1377 (RB). Petrópolis, 27.VII.1978, fl., G. Martinelli 4856 (RB); 22.IV.1980, fl., T. Plowman et al. 10126 (RB 337100). Teresópolis, 27.XI.2001, fl. e fr., M. Nadruz et al. 1503 (RB); 27.XI.2001, fl. e fr., M. Nadruz et al. 1504 (RB ).

É encontrada geralmente como terrestre e rupícola, podendo ser hemiepífita, em locais bastante úmidos e sombreados das florestas montana e de altitude, entre 950-1600 m altitude. Anthurium parvum vinha sendo considerada endêmica da região serrana do estado do Rio de Janeiro, atualmente distribui-se também no município de Ouro Preto (Minas Gerais).

Anthurium parvum é reconhecida principalmente pelo hábito geralmente terrestre, pela lâmina foliar ovada com a base arredondada a cordada, inflorescência geralmente vinácea e presença de curto estípite. A espécie mais semelhante é $A$. hoehnei, a qual difere de $A$. parvum por apresentar pecíolo com margens agudas a carenadas adaxialmente, lâmina foliar com pontos glandulares em ambas as faces, nervura mediana aguda a subcarenada abaxialmente e estípite 1-4,5 cm compr., contra pecíolo com margens obtusas adaxialmente, lâmina foliar sem pontuações glandulares, nervura mediana obtusa abaxialmente e estípite de 0,2 a 1,1 cm compr. em A. parvum.

Floresce de fevereiro a novembro e frutifica, até o momento, no mês de dezembro.

Para informações a respeito da localização exata da coleta do tipo de $A$. mendonçai, veja Coelho \& Mayo (2007).

29. Anthurium pilonense Reitz, Sellowia 8: 56. 1958 [1957].Tipo:BRASIL. SANTACATARINA: Pilões, Palhoça, 05.IV.1956, R. Reitz \& R. Klein 2955 (holótipo - HBR!).

Fig. 11d

Rupícola; caule não observado; entrenós cerca de 2,5 mm compr.; catafilos e profilos triangulares, acastanhados em material seco, inteiros a levemente decompostos no ápice, decompostos a caducos para a base do caule, 3,6-10 cm compr.; bainha 2,7 cm compr.; pecíolo cilíndrico, 30-50 cm compr.; genículo 0,9-1,1 cm compr.; lâmina foliar deflexa, levemente cartácea em material seco, não pruinosa abaxialmente, pontos glandulares ausentes, subhastada com lobos posteriores oblongos, obtusos e divergentes, ápice agudo apiculado, base curtamente estreitada, seio arqueado com pequena decorrência no pecíolo, 30-40 × 10,7-12 cm; nervura mediana não observada; nervuras secundárias 15-16 em ambas as faces; nervura basal 1 para cada 
lobo, com 1 nervura basioscópica e nenhuma acroscópica; pedúnculo 30-54 cm compr.; espata linear-lanceolada, curtamente acuminada, esverdeado-vinácea, $6 \times 0,7 \mathrm{~cm}$, formando ângulo agudo com o pedúnculo; espádice curtamente estipitado, $8 \mathrm{~cm}$ compr., estípite 0,3 cm compr., esverdeado-vináceo; bagas não observadas.

Material examinado: BRASIL. SANTA CATARINA: Palhoça, 5.IV.1956, fl., Reitz et al. 2955 (HBR).

Espécie muito semelhante a A. acutum e A. victorii Nadruz \& Catharino, diferindo destas por diversas características morfológicas.

A espécie possui o hábito rupícola, crescendo na floresta submontana à $300 \mathrm{~m}$ altitude, sendo ombrófila e esciófila. Floresce, até o momento, no mês de abril. Sem dados de frutificação.

O único registro de localidade de $A$. pilonense é aquele apresentado na etiqueta do material tipo, sendo endêmica da região da grande Florianópolis, no município de Palhoça, Santa Catarina. Pressupõe-se que a espécie em questão seja considerada rara devido ao grande número de coletas de Angiospermas realizadas no estado de Santa Catarina, visando a elaboração da Flora Ilustrada Catarinense (Reitz 1957).

Por possuir uma extensão de presença estimada em menos de $100 \mathrm{~km}^{2}$ com tamanho da população estimada em menos de 250 indivíduos maduros, A. pilonense é considerada Criticamente em Perigo (CR) pelas categorias da IUCN (1998).

30. Anthurium regnellianum Engl. in Mart., Fl. Bras. 3(2): 96. 1878. Tipo: BRASIL. SÃO PAULO: fl., A.F. Regnell n. III. 1297 (holótipo - S!).

Fig.11e

Terrestre, raramente hemiepífita; caule ereto; entrenós curtíssimos; catafilos e profilos inteiros a levemente decompostos no ápice, levemente decompostos a decompostos, geralmente caducos para a base do caule, $1,2-$ $5 \mathrm{~cm}$ compr.; bainha $0,9-1,3 \mathrm{~cm}$ compr.; pecíolo obtuso abaxialmente, levemente sulcado com margens obtusas adaxialmente, 10,6-17,4×0,15 cm; genículo levemente mais espesso que o pecíolo, 8-9 mm compr.; lâmina foliar membranácea em material seco, não pruinosa abaxialmente, pontos glandulares ausentes, levemente arcoada, oblonga a raramente lanceolada, ápice agudo a subrostrado, curtamente apiculado, base obtusa, truncada, subcordada, raro curtamente estreitada, 9,8-19,5 × 4,4-8,6 cm larg.; nervura mediana roliça abaxialmente, aguda a subaguda adaxialmente; nervuras basais $1-2$, quando 1 terminando na margem basal, quando 2 a mais externa terminando na margem da região basal, a mais interna terminando na margem da região mediana da lâmina; nervuras secundárias tênues em ambos as faces, 6-10 em ambas as faces; nervuras coletoras saindo da base ou, raramente, acima da base laminar, 2-9 mm afastadas da margem; pedúnculo $10-15 \mathrm{~cm}$ compr.; espata membranácea, lanceolada, formando ângulo subagudo com o pedúnculo, $3,5 \times 0,7-0,8 \mathrm{~cm}$; espádice séssil a curtamente estipitado, cilíndrico, 2,5-4×0,3 cm, estípite 3 mm compr.; bagas não observados.

Material selecionado: BRASIL, SÃO PAULO: Amparo, 5.IV.1943, fl., M. Kuhlmann 211 (SP). Santo André, V.1912, fl., H. Lüderwaldt 10728 (NY).

Engler (1878) inseriu a espécie $A$. regnellianum na seção Parabasium, tendo em vista as características apresentadas: caule frequentemente contraído, pecíolo longo, lâmina pergaminácea, oblonga e base cordadoemarginada, duas nervuras secundárias basais em ambas as faces, espata linear-lanceolada, decorrente na base e bagas subglobosas esverdeadas. Nessa seção encontravam-se outras espécies, tais como: A. trinervium Kunth, A. laucheanum K. Koch, A. maximiliani Schott e A. Ihotzkyanum que, atualmente (Engler 1905), estão agrupadas na subseção Obscureviridia. Em 1879 Engler repete a citação para $A$. regnellianum, mantendo-a na seção Parabasium de Schott. Já em 1898 Engler sinonimiza a seção Parabasium na seção Urospadix, situando acertadamente $A$. regnellianum na recém 
criada subseção Flavescentiviridia, mantendo as outras espécies citadas acima na subseção Obscureviridia. Em 1905, Engler manteve a espécie em questão na subseção Flavescentiviridia, tendo em vista apresentar lâmina foliar membranácea (e nervuras secundárias proeminentes abaxialmente), a partir da análise de apenas exsicatas. Madison (1978), erroneamente e sem qualquer explicação, relaciona $A$. regnellianum como sinônimo de A. sinuatum Benth. ex Schott. A espécie de Engler possui hábito terrestre, caule curto, lâmina foliar simples com margem inteira sendo obtusa a levemente emarginada na base, enquanto $A$. sinuatum apresenta caule escandente epifítico, lâmina foliar composta em 5-7 segmentos, folíolos com margem sinuadas e atenuados para a base (Madison 1978). Espécie muito semelhante a A. hoehnei, a qual diferencia-se, porém, pela presença de pontos glandulares escuros em ambas as faces da lâmina, pela forma navicular da espata e pela presença de estípite longo na base da espádice na primeira, enquanto $A$. regnellianum apresenta lâmina foliar sem pontos glandulares, forma da espata aplanada e espádice séssil ou com presença de estípite muito curto de 0,1 $\mathrm{cm}$ compr. A. regnellianum pode ser reconhecida pela lâmina foliar oblonga com a base truncada a sub-cordada.

Engler (1878) ao descrever $A$. regnellianum não cita a localização da coleta de Regnell n. III. 1297, mas consultando-se a etiqueta da exsicata constatou-se a indicação "Cajuru” como provável local da coleta do material tipo. Na região nordeste do estado de São Paulo existe o município Cajuru, onde inicialmente pensou-se tratar da localidade tipo, mas ao consultar Urban (1906) nota-se que Regnell, quando esteve em São Paulo, coletou somente na parte oriental, ou seja, próximo ao mar. Juntando isso a informação de que o nome original da Reserva Biológica do Alto da Serra, no município de Santo André (São Paulo), era "Estação Biológica” ou "Parque Cajurú", corrobora a afirmação de que a Reserva Biológica é a localidade tipo de $A$. regnellianum (Catharino com. pess.). Atualmente A. regnellianum distribui-se pelas regiões de Campinas e metropolitana de São Paulo, nas florestas montanas em altitudes que variam entre 670 e $890 \mathrm{~m}$, em locais sombreados e úmidos com o hábito geralmente terrestre.

Floresce de março a abril, sem registro de frutificação.

A. regnellianum possui uma extensão de presença estimada em menos de $100 \mathrm{~km}^{2} \mathrm{com}$ tamanho da população em cerca de menos de 250 indivíduos maduros, sendo considerada Criticamente em Perigo (CR) pelas categorias da IUCN (1998).

31. Anthurium sellowianum Kunth, Enum. Pl. 3: 70. 1841.Tipo: Brasilia meridionalis, (fl), F. Sellow 287 (holótipo - B!). Fig. 12a-d

A. viride C. Koch et Bouché, Index Sem. Berlin. 1855: 6. 1855/1856. Tipo: Impressão a lápis e desenho do espécime tipo no herbário de K. Koch (B†), 2 Set. 1878, N.E. Brown s.n. (neótipo - K! designado por Coelho, 2007)

A. longilaminatum Engl., Bot. Jahrb. Syst. 25: 399. 1898. Tipo: Brasilia. A. Glaziou s.n, s.d. (fl). (=holótipo - B!).

A. crassipes Engl., Bot. Jahrb. Syst. 25: 400. 1898. Tipo: Brasília. Espécime sem dados de coletor, número de coleta, localidade ou data, autografado por A. Engler como "Anthurium crassipes”. (holótipo - B†, neótipo - B! designado por Coelho, 2007).

Epífita, ocasionalmente terrestre ou rupícola; entrenós curtos, $0,1-1,5$ cm compr.; catafilos e profilos esverdeado-rosados, esverdeado-amarelados, esverdeados, acastanhados, cor-de-palha, inteiros, levemente decompostos a decompostos no ápice, acastanhados, cor-de-palha, inteiros a decompostos, caducos para a base do caule, 1,5-13,2 cm compr.; bainha $0,9-9$ cm compr.; pecíolo esverdeado, achatado a raramente sulcado e com margens agudas a ligeiramente carenadas adaxialmente, geralmente obtuso, raramente subcarenado a carenado abaxialmente, raro lateralmente compresso, 
2,1-37,3 cm compr.; genículo mais inchado, concolor, levemente mais escuro, levemente mais claro a mais claro que o pecíolo a esverdeado-vináceo, 0,5-3,3 cm compr.; lâmina foliar esverdeada discolor, ereta, cartácea a raramente membranácea em material seco, cartácea em material vivo, não pruinosa abaxialmente, pontos glandulares ausentes, lanceolada, linear-lanceolada, igualmente estreitada para ambas as extremidades, ápice agudo a rostrado, apiculado, base obtusa, subaguda a raramente cuneada, 15,5-89,9 $\times$ 2,2-26,6 cm; nervura mediana aguda a obtusa, obtusa a quase achatada em direção a base e aguda em direção ao ápice adaxialmente e obtusa no ápice e aguda a carenada no terço inferior a subcarenada, carenada abaxialmente, nervuras secundárias primárias 10-29 em ambas as faces, geralmente tênues, levemente impressas a raramente impressas adaxialmente, levemente proeminentes a raramente proeminentes abaxialmente a obscuras em
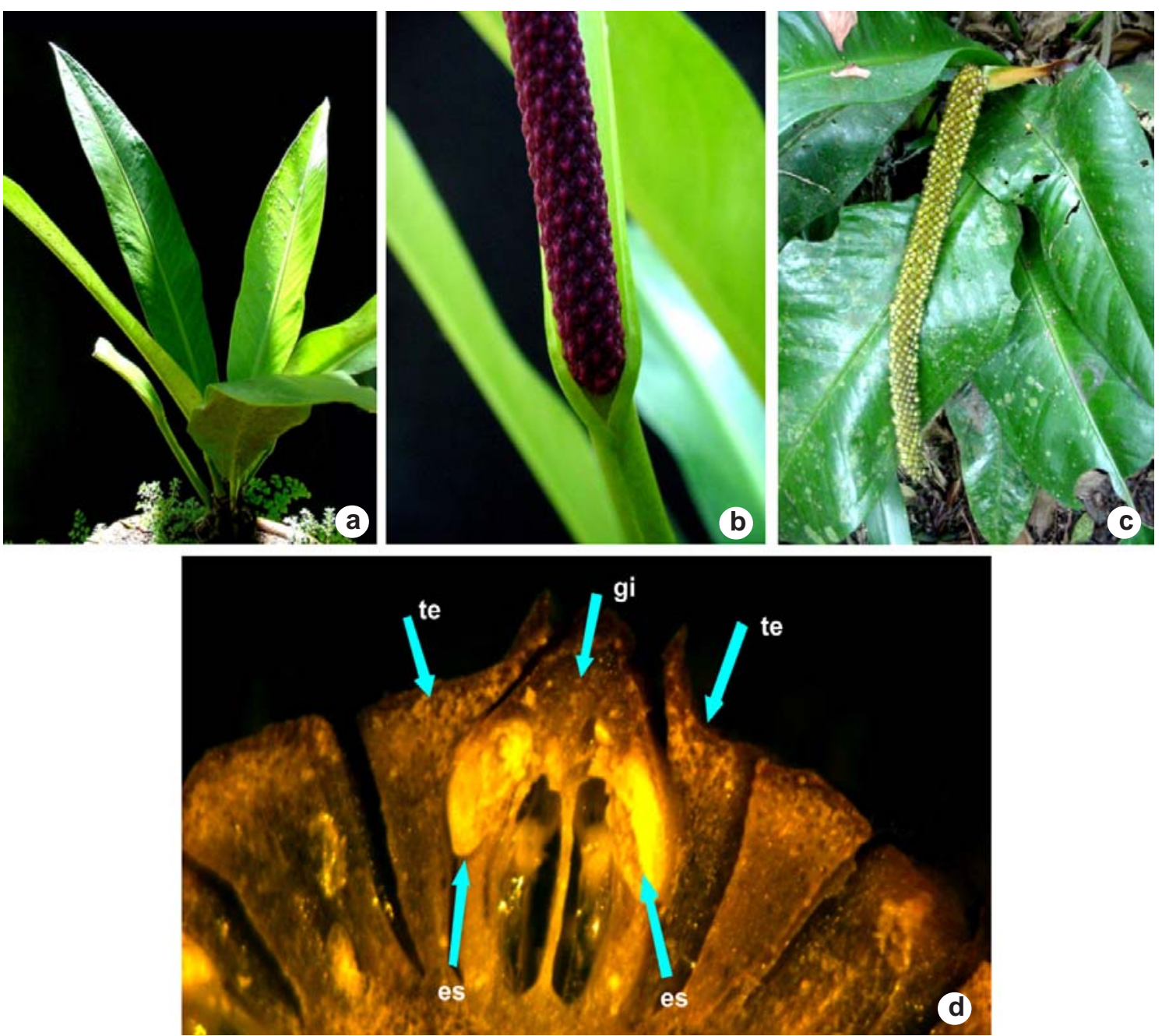

Figura 12 -a-d. A. sellowianum - a. hábito (Nadruz 1458 cultivado no JBRJ); b. inflorescência; c. infrutescência (Nadruz 1458 cultivado no JBRJ); d. detalhe da flor, em seção longitudinal, evidenciando tépalas (te), estames (es) e gineceu (gi) (Nadruz 1527 cultivado no JBRJ).

Figura 12 - a-d. A. sellowianum - a. habit (Nadruz 1458 cultivated at the JBRJ); b. inflorescence; c. infrutescence (Nadruz 1458 cultivated at the JBRJ); d. detail of the flower, longitudinal section, showing the tepals (te), stamens (es) and gynoecioum (gi) (Nadruz 1527 cultivated at the JBRJ). 
ambas as faces; nervuras coletoras nascendo na base da lâmina ou um pouco acima dela, 0,2$1,9 \mathrm{~cm}$ afastadas da margem na região mediana; pedúnculo geralmente esverdeado, esverdeado-alvacento, rosado, esverdeadoavermelhado, avermelhado-vináceo, vináceo, acastanhado-vináceo, raramente cilíndrico a geralmente 1-6-carenado, 10,6-67 cm compr.; espata geralmente esverdeada, esverdeada sendo arroxeada nas margens, esverdeadoavermelhada, rosada, vinácea, acastanhadoavermelhada, acastanhada, membranácea, cartácea, lanceolada, linear-lanceolada, apiculada, 3,6-15,6 × 0,5-2,1 cm, decorrência 0,3-4,25 cm formando ângulo agudo com o pedúnculo; espádice séssil a levemente estipitado, esverdeado, vináceo, arroxeado, acastanhado-avermelhado, acastanhadoarroxeado, acastanhado, 4,1-24,8 cm compr., estípite $0,2-0,6 \mathrm{~cm}$ compr., tépala acastanhadoavermelhada a acastanhada no espádice em frutificação, pólen amarelado; bagas imaturas com ápice esverdeado, quando maduras totalmente esverdeadas, amareladas a raramente alaranjadas.

Material selecionado: BRASIL. MINAS GERAIS: Araxá, 29.II.1976, fl., G. Davidse et al. 10893 (SP). PARANÁ: Antonina, 11.XII.1993, fl., G. Hatschbach 59448 (RB). Curitiba, 22.IX.1953, fl., R. Reitz 5716 (HBR). Guaraqueçaba, 16.VIII.1999, fl., G. Gatti et al. 620 (UPCB). Guaratuba, 6.VII.1958, fl., G Hatschbach 4859 (MBM); 14.XII.1971, fl., H. P.L. Krieger 11134 (CESJ, RB). Matinhos, 17.VIII.1959, fl., G Hatschbach 6205 (MBM). Morretes, 8.XII.2001, fl., P.H. Labiak al. 2002 (MBM). Paranaguá, 16.XII.1999, fl., G. Hatschbach et al. 69857 (RB). São José dos Pinhais, 31.X.1996, fl., J.M. Silva et al. 1764 (RB). Tunas do Paraná, 21.XI.1998, fl. e fr., J.M. Silva et al. 2630 (MBM). RIO DE JANEIRO: Parati, 19.X.1993, fl., $R$. Marquete 1235 (RB). SANTA CATARINA: Ilhota, 17.I.1971, fl., R. Reitz 7436 (HBR). Itajaí, 07.I.1955, fl. e fr., R. Reitz et al. 2357 (HBR). Joinville, 26.V.1957, fl., R. Reitz et al. 4239 (HBR). Volta Grande, 20.XII.1911, fl., P.K. Dusén 13431 (NY). SÃOPAULO: Bananal, 23.VI.1978, fl., G. Martinelli 4682 (RB). Bertioga, 15.IV.1999, fr., D. Sampaio et al. 236 (USC). Biritiba-Mirim, 8.IX.1991, fl., S.J.G. Silva et al. 235 (SP). Cananéia, 17.VII.2002, fl., M. Nadruz al. 1492 (RB). Caraguatatuba, 09.IX.2000, fl., R.S. Bianchini et al.1460 (SP). Cunha, 12.XII.1996, fl.,A.P. Bertoncini et al. 727 (ESA). Eldorado, 4.IX.1995, fl., V.C. Souza et al. 9130 (ESA). Iguape, 12.I.1999, fl., M.R. Gorenstein et al. 142 (ESA). Iperó, 1.XII.1998, fl., A.M.G.A. Tozzi et al. 119 (BHCB). Iporanga, 22.IV.1994, fl., V.C. Souza et al. 12321 (ESA). Itanhaem, 8.X.1995, fr., V.C. Souza et al. 9240 (ESA). Itú, 4.XII.1924, fl., A. Gehrt s.n. (NY). Juquiá, 16.II.1995, fr., J.P. Souza et al. 114 (ESA). Mogi das Cruzes, 8.IX.1991, fl., R.C. Prando 17(SP); 24.IV.2000, fl., W. Forster et al. 539 (ESA). Pariquera-Açu, 13.IX.1995, fl., N.M. Ivanauskas 358 (ESA). Peruíbe, 24.VI.1994, fl., M.M.R.F. Melo et al. 1095 (SP); 23.V.2002, M. Nadruz et al. 1476 (RB). Praia Grande, 25.X.1898, fl., A. Loefgren 4066 (fotoparatipo - SP!, NY!). Registro, 6.X.1982, fl., G. Hatschbach \& R. Kummrow, 45528 (MBM). Salesópolis, 23.VII.1971, fl., M.C. Vianna et al. 433 (GUA); 31.VIII.1983, fr., A.C. Filho 1503 (SP). Santo André, 14.X.1992, fl.,A.C. Almeida s.n. (ESA 8147); 11.III.2003, fl. efr., M. Nadruz et al. 1553 (RB). São Luis do Paraitinga, 5.IX.1996, fl., V.C. Souza et al. 12247 (ESA). São Miguel Arcanjo, 5.VI.1992, fl., J. Lombardi 102 (BHCB). São Paulo, 20.III.2002, fl. e fr., M. Nadruz et al. 1459 (RB). São Sebastião, 18.XII.1998, fl., V.C. Souza et al. 21655 (ESA). Tapiraí, 9.IX.1994 fl. fr., P.H. Miyagi et al. 236 (ESA, SP). Ubatuba, 7.IX.1998, fl., O.S. Ribas et al. 2687 (MBM); I.2000, fl., A.I.L. Pinheiro et al. 30 (SP).

Anthurium sellowianum pode ser encontrada com hábito geralmente epifítico, ocasionalmente rupícola ou terrestre. Ocorre em áreas de mata úmida, sombreada a semisombreada, em florestas de baixada, submontana e montana até $1200 \mathrm{~m}$ altitude. Tem sua distribuição na Região Sudeste e Sul, de Minas Gerais (Araxá), passando pelo extremo Sul do Rio de Janeiro, até o norte catarinense.

Pode ser confundida com A. intermedium, sendo diferenciada desta pelos catafilos geralmente esverdeados, pecíolo mais espesso, nervuras secundárias geralmente tênues, pedúnculo mais espesso, geralmente até 5-carenado e com distribuição do sul do estado do Rio de Janeiro até Santa Catarina, enquanto A. intermedium apresenta catafilos geralmente variando de esverdeados até avermelhados, pecíolo mais fino, nervuras secundárias geralmente impressas adaxialmente e proeminentes abaxialmente, pedúnculo mais fino e geralmente cilíndrico até 3carenado, distribuindo-se do sul do estado do Rio de Janeiro até o extremo Sul da Bahia. De um 
modo geral A. sellowianum é uma espécie mais robusta em comparação àquelas espécies que faziam parte do “complexo harrisii”, incluindo $A$. intermedium. Provavelmente os espécimes denominados de A. harrisii ou A. harrisii var. beyrichianum Engl., por alguns autores, para os estados de Santa Catarina (Reitz 1957) e Paraná (Angely 1965), devem tratar-se de $A$. sellowianum.

Floresce o ano todo e frutifica nos meses de janeiro a abril, julho a setembro e novembro. Foi observado no espécime M. Nadruz 1492 o fenômeno de viviparidade, onde a germinação da semente ocorre no próprio espádice, com formação de plântula.

32. Anthurium simonii Nadruz, Aroideana 29: 99-100. 2006.

Fig. 13a-b

Tipo: BRASIL. RIO DE JANEIRO: Parati, Distrito de Parati-Mirim, Ilha da Cotia, face Sul, 19.XI.1992, fl., M.Nadruz et S.J.Mayo 808 (holótipo - RB!).

Terrestre, raramente rupícola ou hemiepífita; caule ereto; entrenós $0,2-2 \mathrm{~cm}$ compr.; catafilos e profilos membranáceos, esverdeados, rosados, avermelhados ou avermelhados em direção a base quando novos tornando-se cor-de-palha, acastanhados, inteiros a decompostos no ápice, acastanhados, pouco persistentes a caducos, fibrosos em direção a base do caule, 1,3-11 × 1,3 cm; bainha 1-6,5 cm compr.; pecíolo esverdeado-avermelhado quando novo, esverdeado, esverdeado com nuança arroxeada, rosado, vináceo, achatado, levemente sulcado a canaliculado, com margens agudas a carenadas adaxialmente, raramente obtuso, agudo a geralmente 1-3 carenado abaxialmente, 5,1-38,65 cm compr.; genículo mais claro e mais espesso que o pecíolo, 0,31,7 cm compr.; lâmina foliar esverdeada discolor, mais brilhante adaxialmente, ereta, cartácea em material vivo, cartácea a membranácea em material seco, não pruinosa abaxialmente, pontos glandulares ausentes, lanceolada, linear-lanceolada, raro igualmente estreitada para ambas as extremidades a geralmente mais estreitada em direção a base, ápice agudo, agudo curtamente acuminado, subrostrado, curtamente apiculado, base geralmente longamente cuneada, com a extremidade basal raramente aguda a freqüentemente obtusa, 30,8-72,3 × 4,1-14,1 $\mathrm{cm}$, nervura mediana totalmente aguda, arredondada a aguda sendo levemente achatada na base abaxialmente, roliça sendo as vezes carenada na base a carenada abaxialmente; nervuras secundárias levemente impressas a impressas adaxialmente e levemente proeminente a proeminentes abaxialmente, 1128 em ambas as faces; nervuras coletoras nascendo na base ou um pouco acima dela, 0,2$1,1 \mathrm{~cm}$ afastadas da margem; pedunculo cilíndrico a 1-carenado, esverdeado, esverdeado-arroxeado, vináceo, avermelhado, acastanhado-avermelhado, 15,2-56,7 cm compr.; espata esverdeada, esverdeadovinácea, rosada, avermelhada, vinácea, acastanhado-avermelhada, marcescente quando passada, linear-lanceolada, acuminada, triangular, 3,9-9,2 × 0,3-1,2 cm, decorrência 0,4-1,6 cm formando ângulo agudo com o pedúnculo; espádice avermelhado, vináceo, acastanhado, acastanhado-vináceo, 4-12 cm compr., séssil; bagas jovens esverdeadoarroxeadas no ápice, maduras vináceas a arroxeadas no ápice e esverdeadas a esverdeado-esbranquiçadas para a base.

Material selecionado: BRASIL. RIO DE JANEIRO: Parati, 17.V.1995, fl., R. Marquete et al. 2162 (RB); 2.XII.1995, fl., S.P. Oliveira et al. 09(RB). Petrópolis, 18.XI.1992, fl. e fr., M. Nadruz et al. 803 (RB); 18.XI.1992, fl. e fr., M. Nadruz et S. Mayo 801 (RB).

Possui hábito geralmente terrestre, rupícola e raramente hemiepífita, sendo encontrada nas florestas sombreadas e úmidas, do nível do mar até cerca de $600 \mathrm{~m}$ altitude. Até o momento é endêmica do estado do Rio de Janeiro, com maior concentração no município de Parati.

Espécie semelhante a $A$. harrisii e $A$. urvilleanum Schott, diferindo principalmente por características referentes à forma da lâmina foliar, coloração das bagas e distribuição geográfica.

Floresce nos meses de maio, junho, agosto e novembro, frutificando nos meses de agosto e novembro. 
Anthurium simonii, segundo a lista vermelha das espécies ameaçadas da IUCN (1998), encontra-se Em Perigo (EN), por possuir uma área estimada de distribuição menor que $5.000 \mathrm{~km}^{2}$, não existindo mais que cinco localidades de ocorrência. É recomendável a continuidade de coletas nas áreas adjacentes a fim de que se tenha um aumento do conhecimento das espécies do grupo, e uma verdadeira amostragem de $A$. simonii.

33. Anthurium unense Catharino \& Nadruz, Aroideana 29: 99-100. 2006. Fig. 13c-d Tipo: BRASIL, SÃO PAULO, Município de São Sebastião, P.E. da Serra do Mar, Cachoeira do Sítio Urucurana, trilha do


Figura 13 - a-b. Anthurium simonii - a. hábito; b. detalhe da base obtusa da lâmina foliar e margens carenadas (cr) do pecíolo (Nadruz 808). c-d. A. unense - c. hábito mostrando lâmina foliar com a superfície adaxial bulada; d. inflorescência, exibindo a espata (ep) navicular (Catharino s/n cultivado no JBRJ). e-f. A. urvilleanum - e. lâmina foliar (Nadruz 1399 cultivado no JBRJ); f. inflorescência, evidenciando o ângulo agudo (ae) formado pela espata em relação ao pedúnculo.

Figura 13 - a-b. Anthurium simonii - a. habit; b. detail of the obtuse base of the leaf blade and carenated margins (cr) of the petiole (Nadruz 808). c-d. A. unense - c. habit showing leaf blade with bulated abaxial surface; d. inflorescence, showing the navicular spathe (ep) (Catharino $s / n$ cultivated at the JBRJ). e-f. A. urvilleanum - e. leaf blade (Nadruz 1399 cultivated at the JBRJ); f. inflorescence, showing the acute angle (ae) between the spathe and the peduncle. 
escorrega, às margens do Rio Una, $130 \mathrm{msm}$,

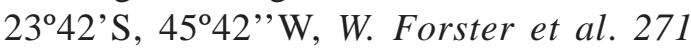
(holótipo - MBM !).

Terrestre; caule ereto; entrenós $1,5-8$ mm compr.; catafilos e profilos rosados a vináceos, acastanhados e inteiros no ápice, inteiros, persistentes a cor de palha para a base do caule, $1-4,4 \mathrm{~cm}$ compr.; bainha $0,7-2 \mathrm{~cm}$ compr.; pecíolo esverdeado, sulcado a raramente achatado com margens agudas a subcarenadas adaxialmente, obtuso abaxialmente, levemente rugoso, 6,9-26,4 cm compr.; genículo 0,6-1,5 cm compr.; lâmina foliar membranácea a subcartácea, face adaxial bulada, deflexa, ovado-elíptica, ápice obtusoacuminado curtamente apiculado, base cordada, seio subespatulado a triangular, lobos posteriores arredondados, não pruinosa abaxialmente, presença de pontos glandulares somente na face adaxial, 14,6-22,4 × 7,5-14 cm; nervura mediana aguda adaxialmente, subcarenada abaxialmente; nervuras basais 1-2, sendo que a mais externa desaparece na margem da base dos lobos posteriores, a mais interna termina na margem do terço basal da lâmina; nervuras secundárias 3-10 em ambas as faces, fortemente impressas na face adaxial dando uma aparência bulada e proeminentes na face abaxial; nervuras coletoras formando-se na base laminar, 4,5-8 $\mathrm{mm}$ afastadas da margem; pedúnculo anguloso, avinosado em pré-antese, tornando-se esverdeado, 7,9-50,3 cm compr.; espata esverdeada, navicular, lanceolada, linearlanceolada, subovada, $1,2-4 \times 0,4-0,7 \mathrm{~cm}$, formando ângulo reto com o pedúnculo; espádice estipitado, avermelhado, acastanhado, 1,5-6,1 cm compr., estípite 0,7-3,7 cm compr.; bagas não observadas.

Material utilizado: BRASIL. SÃO PAULO: 27.VIII.1972, fl., B. Marx s.n. (parátipo - RB!).

Espécie de hábito terrestre, comumente encontrada no interior da floresta atlântica baixomontana, não superior a $130 \mathrm{~m}$ altitude, na proximidade de rios em locais sombreados, com registro somente no vale do Paraíba paulista.

Espécie semelhante a A. hoehnei, diferenciando desta principalmente pelo pecíolo esverdeado, base da lâmina foliar cordada, pelas nervuras secundárias e basais mais impressas adaxialmente, dando a forma bulada à lâmina foliar e pelo número de nervuras basais 3-4, enquanto A. hoehnei apresenta pecíolo esverdeado-vináceo, base da lâmina foliar truncada a cordada, nervuras secundárias e basais não dando a forma bulada a lâmina foliar e número de nervuras basais 1-2.

Floresce no mês de abril, sem registro de frutificação.

Atualmente A. unense encontra-se em Criticamente em Perigo (CR), segundo os critérios da IUCN (1998), por possuir uma população estimada em menos de 250 indivíduos maduros, com nenhuma subpopulação estimada contendo mais que 50 indivíduos maduros. É recomendável a continuidade de coletas nas áreas de ocorrência a fim de que se tenha um aumento do conhecimento das espécies de Anthurium, e uma verdadeira amostragem de $A$. unense.

34. Anthurium urvilleanum Schott, Prod. Syst. Aroid.: 459. 1860. Tipo: BRASIL. SANTA CATARINA: J.S.C.D. d'Urville s.n. (=holótipo - B $†$ ); Schott Icone 446 (neótipo - W! designado por Coelho, 2007).

Fig. 13e-f, 14a-f

Terrestre, ocasionalmente rupícola e ou hemiepífita; caule ereto; entrenós 0,3-2,2 cm compr.; catafilos e profilos avermelhados quando novos, rosados, esverdeado-rosados, creme-esverdeados, esverdeados, esverdeadoamarelados, acastanhados, cor-de-palha, inteiros a decompostos, persistentes no ápice, acastanhados, raramente inteiros a decompostos, persistentes a geralmente caducos para a base do caule, 0,9-10,2 cm compr.; bainha $0,75-8,2 \mathrm{~cm}$ compr.; pecíolo jovem esverdeado sendo rosado na base, tornando-se esverdeado a avermelhado no ápice e rosado a avermelhado na base a totalmente esverdeado, rosado, esverdeadorosado, levemente achatado a achatado, canaliculado a sulcado com margens carenadas adaxialmente, obtuso, agudo a geralmente 1-carenado abaxialmente, 3,8-34,4 $\times 0,4-0,5 \mathrm{~cm}$; genículo concolor, esverdeadorosado a vináceo, mais claro a levemente mais escuro e mais espesso que o pecíolo, 0,25-3 

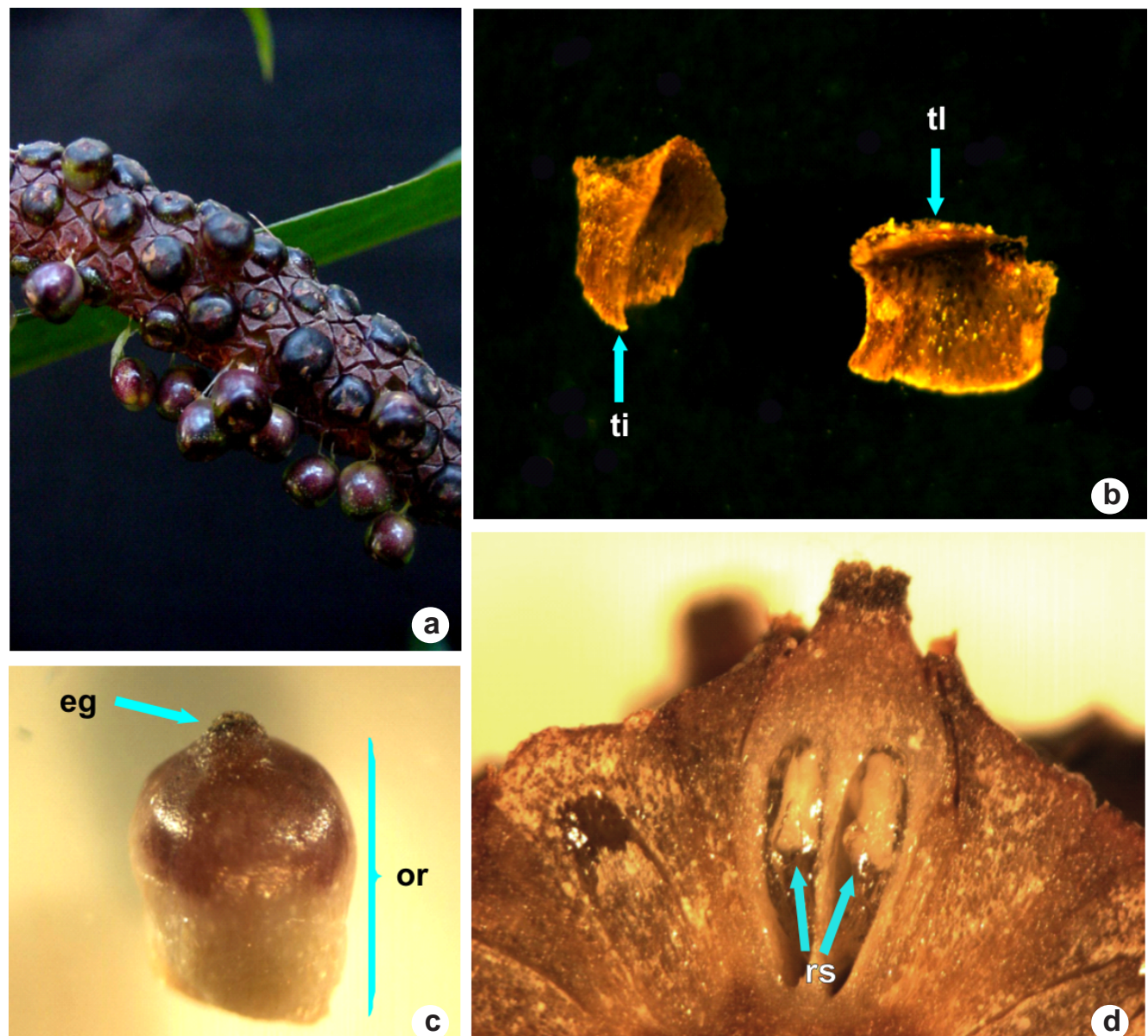

or

C
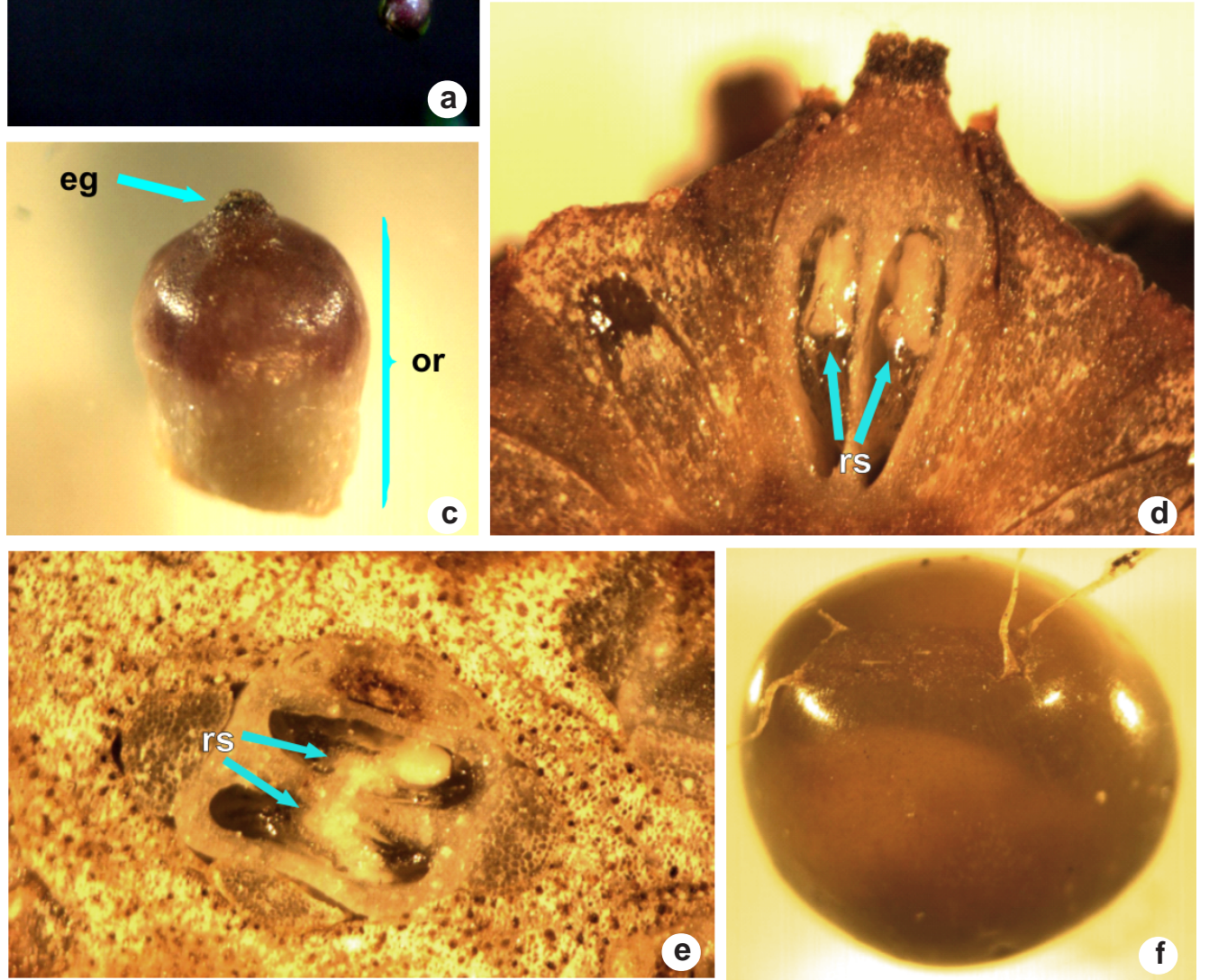

Figura 14 - a-f. Anthurium urvilleanum - a. detalhe da infrutescência, evidenciando bagas (Nadruz 1446 cultivado no JBRJ). b. detalhe das tépalas laterais (tl em vista ventral) e interna (ti) (Braga 7150 cultivado no JBRJ); c. detalhe do gineceu com ovário (or) e estigma (eg) séssil (Nadruz 1351 cultivado no JBRJ); d. ovário em corte longitudinal exibindo um rudimento seminal (rs) por lóculo de placentação axilar subapical (Nadruz 1395 cultivado no JBRJ); e. ovário em corte transversal, evidenciando dois lóculos com um rudimento seminal cada (Nadruz 1442 cultivado no JBRJ); f. vista basal do fruto (Nadruz 1442 cultivado no JBRJ).

Figura 14 - a-f. Anthurium urvilleanum - a. detail of the infrutescence, showing berries (Nadruz 1446 cultivated at the JBRJ). b. detail of the lateral (tl, ventral view) and internal (ti) tepals (Braga 7150 cultivated at the JBRJ); c. detail of the gynoecioum with ovary (or) and sessil stigma (eg) (Nadruz 1351 cultivated at the JBRJ); d. longitudinal section of the ovary showing one seminal rudiment (rs) for each locus of subapical axilar placentation (Nadruz 1395 cultivated at the JBRJ); e. transversal section of the ovary, showing two loci with one seminal rudiment each (Nadruz 1442 cultivated at the JBRJ); f. basal view of the fruit (Nadruz 1442 cultivated at the JBRJ). 
cm compr.; lâmina foliar geralmente acastanhada em material seco, jovem avermelhada tornando-se esverdeada discolor, membranácea a cartácea em material seco e vivo, ereta, não pruinosa abaxialmente, pontos glandulares ausentes, lanceolada a linearlanceolada, ápice agudo a geralmente rostrado, curtamente apiculado, base cuneada, sendo mais estreitada em direção a base, 15,9-73,3 $\times 2,6-16,55 \mathrm{~cm}$; nervura mediana aguda no comprimento total a subcarenada da metade para a base e raramente obtusa a achatada para o ápice adaxialmente, aguda a geralmente carenada no comprimento total, aguda a geralmente carenada para o ápice a levemente achatada para a base abaxialmente; nervuras secundárias impressas, levemente impressas ou raramente obscuras adaxialmente, proeminentes a levemente proeminentes abaxialmente a raramente tênues em ambas as faces, 7-24 pares, nervuras coletoras nascendo na base da lâmina ou um pouco acima dela, 0,2-1,65 cm afastadas da margem; pedúnculo esverdeado, esverdeado com nuança rosada na base, esverdeado-rosado, esverdeado-vináceo, rosado, avermelhado, vináceo, amarelado no ápice a esverdeadoamarelado para a base, amarelado quando em frutificação, geralmente 2-4-carenado, 9,15$59 \times 0,4-0,5 \mathrm{~cm}$; espata membranácea, cartácea, amarelado-esverdeada, esverdeada, esverdeada com máculas irregulares avermelhado-rosadas, esverdeado-avermelhada, esverdeado-vinácea, avermelhada, vinácea, amarelado-acastanhada, amarronzada a acastanhada quando passada, linearlanceolada, oblongo-lanceolada, lanceolada, acuminada, decorrência 0,1-2,7 cm, formando ângulo agudo a raramente obtuso com o pedúnculo, 1,9-11,1 ×0,5-1,4 cm; espádice cilíndrico, quando novo avermelhado, tornandose arroxeado, vináceo, acastanhado-vináceo, esverdeado-acastanhado, acastanhado, séssil a estipitado, estípite 0,2-2,1 cm compr., 2,5$16,6 \mathrm{~cm}$ compr., bagas imaturas esverdeadas a esverdeadas com ápice vináceo, quando maduras esverdeadas com nuanças vináceas, vináceas no ápice e verde-amareladas a hialinas para a base a raro totalmente vináceas, oblongas, globosas, sendo mais afuniladas para a base, com ápice subachatado a achatado e base achatada a arredondada.

Material selecionado: BRASIL. PARANÁ: Guaratuba, 26.VII.1970, fl., A. Duarte et al. 5333 (RB). Tunas do Paraná, 21.XI.1998, fl., J.M. Silva et al. 2530 (RB). RIO DE JANEIRO: Angra dos Reis, 12.X.2001, fl., Gonçalves et al. 172 (HB); 20.XII.2001 fl., S. Schneider et al. 433 (HB). Mangaratiba, 16.III.2001, fl. e fr., M. Nadruz et al. 1351 (RB); 31.V.2005 fl., M. Nadruz et al. 1633 (RB). Parati, 12.II.2003, M. Nadruz et al. 1541 (RB). Rio de Janeiro, 12.IV.1997, fl., C.M. Vieira et al. 895 (RB); 24.V.1997 fl., C.M. Vieira et al. 938 (RB). Silva Jardim, I.2003, fl., J.M. Braga 7150 (RB). SANTA CATARINA: Itajaí, 20.XII.1955, fl., R. Reitz et al. 2298 (HBR). São Francisco do Sul, 21.II.1952, fl. e fr., R. Reitz 4409 (HBR). SÃO PAULO: Bertioga, 24.III.2000, fl., M. Kirizawa et al. 3401 (SP). Caraguatatuba, 29.VI.1956, fl., J.G. Kuhlmann 3833 (SP). Cunha, 15.XII.1996, fl. e fr., J.P. Souza et al. 959 (ESA). Peruíbe, 21.V.2002, fl. e fr., M. Nadruz et al. 1472 (RB). Picinguaba, 2.X.1975, fl. e fr., D. Araujo et al. 839 (RB). São Sebastião, 22.IX.1962, fl., J. Mattos 10596 (SP); 3.VIII.1985, fl., P.C. Hutchison et al. 8866 (RB). Tapiraí, 9.IX.1994, fl., P.H. Miyagi et al. 236 (HRCB). Ubatuba, 16.VIII.1996, fl., M.A. Assis 843 (HRCB).

Anthurium urvilleanum possui ampla distribuição, ocorrendo desde o nordeste de Santa Catarina, extremo leste do Paraná, em regiões do litoral Sul, macro metropolitana, metropolitana e vale do Paraíba Paulista em São Paulo e nas regiões sul, metropolitana e na baixada litorânea do Rio de Janeiro. Encontrada até $1000 \mathrm{~m}$ altitude, em floresta de restinga, de baixada, submontana e montana, ocorrendo geralmente como terrestre ou rupícola e mais raramente como hemiepífita em locais úmidos, sombreados a semiheliófilos. Floresce e frutifica o ano todo.

Espécie até então conhecida do sul do estado do Rio de Janeiro e São Paulo. Com as recentes coletas, novas populações foram registradas, principalmente aquelas da região da baixada litorânea fluminense, mais especificamente do município de Silva Jardim, muito distante do que se pensava ser o limite norte de ocorrência da espécie (região 
metropolitana do Rio de Janeiro). Anthurium urvilleanum foi descrito por Schoot em 1860. Posteriormente Engler (1905) sinonimizou esta espécie para A. harrisii var. beyrichianum. Tendo em vista, principalmente, a sua distribuição geográfica e a coloração geralmente vinácea no ápice e esverdeada para a base da baga, elevou-se o táxon ao nível de espécie.

Muito semelhante a $A$. intermedium e $A$. harrisii, diferenciando-se de ambas por possuir bagas vináceas no ápice a esverdeadas ou hialinas para a base ou raro completamente vináceas, contra bagas totalmente esverdeadas nas espécies mencionadas. Anthurium urvilleanum possui lâmina foliar com base aguda a longamente cuneada contra lâmina de base subaguda a truncada em $A$. harrisii, e tem sua distribuição do Rio de Janeiro até Santa Catarina enquanto $A$. intermedium ocorre de São Paulo ao extremo sul da Bahia. A lâmina foliar de A. urvilleanum, quando seca, geralmente apresenta uma coloração acastanhado-ferruginosa, mostrando um caráter singular a espécie em questão.

A plasticidade da lâmina foliar, juntamente com variação do hábito, da proeminência e impressão das nervuras secundárias, das formas do pedúnculo, pecíolo e nervura mediana, sugeriu um estudo utilizando números e caracteres morfológicos cromossômicos entre alguns espécimes. Segundo Viegas et. al. (2006) as coletas M. Nadruz 1394, 1442, 1541 e 1543 apresentaram os seguintes resultados: os espécimes M. Nadruz 1541 e 1543, coletados no município de Parati, possuem número cromossômico diplóide básico $(2 n=2 x=30)$, porém M. Nadruz 1543 possui dois cromossomos adicionais, provavelmente cromossomos acessórios B, fazendo com que a fórmula cariotípica não seja idêntica, consequentemente, os espécimes provavelmente distintos; os espécimes $\mathbf{M}$. Nadruz 1394 e 1442, coletados nos municípios de Parati e Silva Jardim respectivamente, possuem $2 n=4 x=60$, podendo ser considerados provavelmente idênticos. Considerando os resultados apresentados e a permanência de dúvidas a respeito da delimitação taxonômica dos espécimes estudados, propõe-se uma reavaliação mais acurada dos caracteres morfológicos vegetativos e reprodutivos, e da caracterização citogenética mais precisa, incluindo estudos de bandeamento e técnicas moleculares.

Observação realizada no material cultivado de A. urvilleanum, constatou-se a visita, provavelmente, de um “tangará”, sobre a infrutescência, alimentando-se de bagas maduras. Com essa informação reforça-se a ornitocoria nas espécies estudadas.

35. Anthurium victorii Nadruz \& Catharino, Aroideana 29: 94. 2006. Tipo: BRASIL. SÃO PAULO: Santo André, Paranapiacaba, Estação Biológica Alto da Serra, mata atlântica nebular, trilha Washington Luiz, 23 46’ S, 46 $18^{\circ} \mathrm{W}$, 900 msm, 11.III.2003, fl., M. Nadruz et al. 1557 (holótipo - SP!, isótipo - RB!).

Fig. 15a, b

Terrestre; caule ereto; entrenós 5-9,5 mm compr.; catafilos e profilos acastanhados, levemente decompostos no ápice, acastanhados levemente decompostos para a base do caule, 2-4,2 cm compr.; bainha 1,21,5 cm compr.; pecíolo esverdeado, cilíndrico sendo levemente achatado na extremidade apical, $17,7-28 \times 0,15-0,3 \mathrm{~cm}$; genículo vináceo em folha jovem, concolor a levemente mais claro e levemente mais espesso que o pecíolo, achatado adaxialmente com margens subagudas, 1,6-2 cm compr.; lâmina foliar esverdeada levemente discolor, deflexa, levemente cartácea, não pruinosa abaxialmente, pontos glandulares ausentes, sagitada, ápice rostrado curtamente apiculado, seio parabólico 13,7-19,85 × 5,85-11 cm; nervura mediana aguda em ambas as faces; nervuras basais 2 para cada lobo posterior, a mais externa terminando na margem na extremidade inferior da lâmina, a mais interna terminando na margem no 1/4-1/3 basal da lâmina, lobos arredondados e direcionados para fora; nervuras secundárias levemente 
impressas adaxialmente, levemente proeminentes abaxialmente, 5 em ambas as faces; nervuras coletoras saindo da base laminar, 4,5-7 $\mathrm{mm}$ afastadas da margem; pedúnculo cilíndrico, esverdeado levemente vináceo a esverdeado, 21,05-24,1 × 0,2 cm; espata membranácea, perpendicular, subdeflexa, enroladas para baixo, lanceolada, esverdeada com a base vinácea, formando ângulo obtuso a quase reto com o pedúnculo, $2,9 \times 0,55 \mathrm{~cm}$; espádice estipitado, afunilado, 3,2-4,5 cm compr., estípite vináceo a esverdeado, 3-8 mm compr.; bagas imaturas esverdeado-vinácea a vináceas.

Material selecionado: BRASIL. SÃO PAULO: Santo André, 11.III.2003, fl. efr., M. Nadruz et al.1557 (RB).

Espécie terrestre, crescendo em mata de encosta montana acima $850 \mathrm{~m}$ alt., em local sombreado e úmido. Apresenta-se endêmica da Estação Biológica do Alto da Serra, município de Santo André (São Paulo), somente com uma localidade de ocorrência.

Floresce e frutifica no mês de março.

Esta espécie é um provável híbrido entre Anthurium acutum e A. marense, ocorrendo em área de distribuição comum às duas espécies apresentando características de ambos as táxons, tais como: catafilos maiores que $3 \mathrm{~cm}$ compr. e levemente decompostos no ápice, pecíolo cilíndrico, lâmina ovadotriangular, pedúnculo cilíndrico acima de 20 cm compr, características essas de $A$. acutum, e nervuras basais terminando na margem laminar e espata formando ângulo obtuso com o pedúnculo, características encontradas em $A$. marense. É reconhecida pelo seu hábito terrestre, juntamente pela forma da lâmina foliar triangular com o seio parabólico e os lobos arredondados.


Figura 15 - a-b. Anthurium victorii - a. hábito; b. inflorescência, evidenciando o ângulo reto da espata em relação ao pedúnculo (ae) (Nadruz 1557 cultivado no JBRJ).

Figura 15 - a-b. Anthurium victorii - a. habit; b. inflorescence, showing the right angle between the spathe and the peduncle (ae) (Nadruz 1557 cultivated at the JBRJ). 
Equivocadamente, quando da publicação da espécie, menciona-se a presença de pontos glandulares na face adaxial da lâmina foliar (Coelho 2006). Numa observação mais pormenorizada, constatou-se a ausência desta característica para $A$. victorii.

Até o momento, $A$. victorii encontra-se Criticamente em Perigo (CR), segundo a lista da IUCN (1998), por ocorrer numa área estimada menor que $100 \mathrm{~km}^{2}$ conhecida somente de uma única localidade. Propõemse mais coletas na localidade tipo em áreas adjacentes à estação, no sentido de melhor delimitar a distribuição de $A$. victorii.

\section{CONSIDERAÇõEs FINAIS}

Nas espécies estudadas a lâmina foliar foi considerada como o caráter taxonômico mais largamente utilizado, assim como sugerido por Croat (1983) em relação a taxonomia do gênero Anthurium como um todo.

Segundo Madison (1978) e Croat (1979, 1983, 1991), a proporção entre os tamanhos do pedúnculo e do pecíolo é um caráter útil na taxonomia de Anthurium, porém somente $A$. bragae, $A$. jureianum e $A$. parvum possuem o comprimento do pedúnculo menor que o pecíolo em relação às outras espécies da subseção.

A utilização de material cultivado, sobre os caracteres reprodutivos incluindo dados sobre proporção do comprimento entre espata e espádice, adicionando estudos anatômicos da espata, constitui-se em grande contribuição na separação das espécies da subseção Flavescentiviridia (Mantovani \& Pereira 2005), bem como na seção Urospadix como um todo.

Segundo Vieira (1999) 17 espécies de Araceae foram registradas em duas áreas contíguas de floresta atlântica (Saibadela e Barra Grande em São Paulo). As sementes de algumas espécies estudadas, incluindo Anthurium harrisii (provavelmente referindose a A. sellowianum ou $A$. urvilleanum), foram encontradas nas amostras fecais de primatas (Cebus apella Linnaeus e Brachyteles arachnoides E. Geoffroy) e de marsupiais (Didelphis aurita Wied, Micoureus demerarae Thomas, Gracilinanus microtarsus Tate). Os dados obtidos sugerem que aráceas são uma fonte alimentar importante para mamíferos arborícolas e semi-arborícolas, e que estes animais podem ser importantes dispersores de sementes deste grupo. Segundo Bown (2000), pelo fato das sementes estarem envolvidas em mucilagem hialina viscosa, sugere que os pássaros se alimentem da polpa esfregando as sementes nos ramos vegetais quando limpam o bico, deixando as mesmas grudadas (pelo menos em relação as epífitas) nos prováveis hospedeiros. Outro fator que corroboraria essa afirmação é a posição estendida para fora do espádice, e pendente, das bagas maduras, seguros por tiras muito finas e pequenas, formadas pela epiderme interna das tépalas, facilitando a apreensão destes, em pleno vôo, pelas aves. Observação realizada no material cultivado de A. urvilleanum, constatou-se a visita, provavelmente, de um "tangará" (Chiroxiphia pareola Linnaeus), sobre a infrutescência, alimentando-se de bagas maduras. Com essa informação reforça-se a ornitocoria nas espécies estudadas.

Os híbridos naturais, como provavelmente A. victorii, são muito comuns no gênero Anthurium, o que induz a realização de observações detalhadas em populações com mais de uma espécie na mesma região.

Os principais caracteres morfológicos utilizados na taxonomia da subseção Flavescentiviridia são: hábito, forma do pecíolo, forma da lâmina foliar, presença ou ausência de pontos glandulares nas faces laminares, proeminência das nervuras secundárias, ângulo formado pela espata no pedúnculo, presença de estípite e cor do fruto.

Segundo as categorias de espécies ameaçadas da IUCN (1998), oito em perigo crítico (CR), seis estão vulneráveis (VU) e cinco em perigo (EN). O grande número de espécies com algum grau de ameaça (19) demonstra a necessidade de conservação das áreas de ocorrência desses táxons. Entretanto, segundo 
a Base de Dados Tropical (BDT 2002), as espécies $A$. parvum e $A$. parasiticum eram consideradas raras e vulneráveis, atualmente são contempladas como quase ameaçada e em menor preocupação, respectivamente.

O cultivo das espécies, além de prático e fácil, foi de extrema importância na complementação das descrições e no acompanhamento do desenvolvimento das partes vegetativas, florais e, em alguns casos, na formação de bagas.

Com as descrições apresentadas enfatiza-se a importância do detalhamento das observações morfológicas vegetativas e reprodutivas do material vivo, principalmente o fruto, na taxonomia da subseção. Em se tratando do fruto, em particular, a coloração é de suma necessidade na separação de grupos ou até mesmo espécies. Consequentemente cuidados devem ser tomados na descrição desses táxons, já que a grande maioria das exsicatas estudadas, no caso de material em fruto, não possui tais informações, contribuindo deste modo para aumentar os obstáculos na determinação dos indivíduos e o número de espécimes herborizados quase sem utilidade.

Um estudo taxonômico-fitogeográfico mais eficaz da seção Urospadix como um todo é indispensável para a confirmação da sistemática do grupo e a manutenção ou não das subseções existentes. Tendo em vista o exemplo em que espécies das subseções Insculptinervia (A. comtum) e Obscureviridia (A. bellum, A. langsdorffii $e$ A. sellowianum) foram transferidas para Flavescentiviridia, é provável uma diminuição no número atual. Entretanto vale ressaltar que a subdivisão da seção Urospadix é imprescindível.

A espécie Anthurium minarum Sakuragui \& Mayo foi posicionada equivocadamente por Coelho (2004) na subseção Flavescentiviridia, porém revendo as características proeminência/ impressão das nervuras secundárias e o grau de discoloração da lâmina foliar, propõe-se o posicionamento da mesma na subseção Obscureviridia.

\section{Agradecimentos}

Aos curadores dos herbários aqui listados o empréstimo do material. Ao CNPq a concessão de bolsa de doutorado. Ao Programa de Pós-graduação em Botânica da Unversidade Federal do Rio Grande do Sul o apoio logístico dispensado, ao IBAMA as licenças de coletas e aos consultores ad hoc pelas valiosas sugestões.

\section{REFERÊNCIAS BIBLIOGRÁFICAS}

Angely, J. 1965. Flora analítica do Paraná: Araceae. Phyton: 193-196.

Barroso, G.M. 1957. Araceae novae. Arquivos do Jardim Botânico do Rio de Janeiro 15: 89-98.

Barroso, G.M. 1959/61. Araceae do Brasil. Arquivos do Jardim Botânico do Rio de Janeiro 17: 5-17.

Bogner, J. \& Hesse, M. 2005. Zamioculcadoideae, a new subfamily of Araceae. Aroideana 28: 3-20.

Catharino, E.L.M. \& Olaio, A.A.R. 1990. Anthurium jureianum Catharino \& Olaio, nova espécie de Araceae endêmica do litoral de São Paulo, Brasil. Hoehnea 17(2): 1-6.

CNIP. 2003. Checklist das plantas do nordeste, versão 13 (base de dados 2.0). Internet URL: http://umbuzeiro.cnip.org.br/db/pnechk/taxa/ 321.html Acessado em 2003.

McNeill, J.; Barrie, F.R.; Burdet, H.M.; Demoulin, V.; Hawksworth, D.L.; Marhold, K.; Nicolson, D.H.; Prado, J.; Silva, P.C.; Skog, J.E.; Wiersema, J.H. \& Turland, N.J. (eds.) 2006. International Code of Botanical Nomenclature (Vienna Code) adopted by the Seventeenth International Botanical Congress Vienna, Austria, July 2005. A.R.G. Gantner Verlag, Ruggell. [Regnum Veg.146].

CATE Araceae. 2009. Creating taxonomic e-science: Araceae. Disponível em http://www.catearaceae.org.

Coelho, M.A.N. 2000. Flora fanerogâmica da Reserva do Parque Estadual das Fontes do Ipiranga (São Paulo, Brasil). Hoehnea 27(1): 33-39.

Coelho, M.A.N. 2004. Taxonomia das espécies de Anthurium (Araceae) seção Urospadix subseção Flavescentiviridia. Tese de Doutorado Universidade Federla do Rio Grande do Sul. p.329

Coelho, M.A.N. \& Leoni, L.S. 2004. Duas espécies novas de Anthurium Schott (Araceae) para o Brasil. Pabstia 15(2): 1-9. 
Coelho, M.A.N. \& Catharino, E. L. M. 2005. Duas espécies novas de Anthurium Schott (Araceae) para o Brasil. Rodriguésia 56 (88): 35-41.

Coelho, M.A.N. 2006. New species of Anthurium (Araceae) from Brazil. Aroideana 29: 91-103.

Coelho, M.A.N. \& Mayo, S.J. 2007. Typifications of names of Brazilian taxa of Anthurium sect. Urospadix (Araceae). Taxon 56(1): 211-225.

Croat, T.B. 1979. Standardization of Anthurium descriptions. Aroideana 2(1): 15-25.

Croat, T.B. 1983. A revision of the genus Anthurium (Araceae) of Mexico and Central America. Part I: Mexico and Middle America. Annals of the Missouri Botanical Garden 70: 211-240.

Croat, T.B. 1985. Collecting and preparing specimens of Araceae. Annals of the Missouri Botanical Garden 72: 252-258.

Croat, T.B. 1991. A revision of Anthurium section Pachyneurium (Araceae). Annals of the Missouri Botanical Garden 78(3): 539-855.

Croat, T.B. 2000. History and current status of systematic research with Araceae. Missouri Botanical Garden. 20p.

Engler, A. 1878. Araceae. In Martius, C.F.P. von, Flora brasiliensis 3(2): 56-88, t. 11 - 102.

Engler, A. 1898. Engler's Botanische Jahrbücher (25): 393, 394, 400, 411, 413, 415.

Engler, A. 1905. Das Planzenreich. IV.23B. AraceaePothoideae, heft 21: 133-174.

Gonçalves, E.G. 2005. A revision of genus Dracontioides Engl. (Araceae), including a new species from Bahia, Brasil. Aroideana 28: 21-31.

Gonçalves, E.G. \& Salviani E.R. 2001. Anthurium mourae Engl. (Araceae): Uma espécie rara recoletada no Parque Nacional do Caparaó. Pabstia 12(2): 1-5.

Guerra M.S. \& Souza M.J. 2002. Como observar cromossomos: um guia de técnicas em citogenética vegetal, animal e humana. Ribeirão Preto. FUNPEC-Editora. 131 p.

Hickey, L.J. 1973. Classification of the architecture of dicotyledonous leaves. American Journal of Botany 60: 17-33.

Holmgren, P.K. \& Holmgren, N.H>. 1998 [continuously updated]. Index Herbariorum: A global directory of public herbaria and associated staff. New York Botanical Garden's Virtual Herbarium. http://sweetgum.nybg.org/ih/ .Index Herbariorum. Part I: The herbaria of the world. URL: http://sciweb.nybg.org/science2/ IndexHerbariorum.asp. Acessado em 2003

Keating, R.C. 2002. Anatomy of the monocotyledons IX. Acoraceae and Araceae. Clarendon Press. Oxford. 322p.

Koch, C \& Augustin, K. 1855. In Index Seminum Horto Berolinense App.: 5. (1856).

Madison, M.T. 1978. The species of Anthurium with palmately divided leaves. Selbyana 2(23): 239-282.

Mantovani, A. \& Pereira, T.E. 2005. Comparative anatomy of leaf and spathe of nine species os Anthurium (section Urospadix subsection Flavescentivirida) (Araceae) and their diagnostic potential for taxonomy. Rodriguesia 56(88): 145-160.

Mayo, S.J. 1991. A revision of Philodendron subgenus Meconostigma (Araceae). Kew Bulletin 46(4): 601-681.

Mayo, S.J.; Bogner, J. \& Boyce, P.C. 1997. The genera of Araceae. Royal Botanical Garden, Kew, London. 370p.

Mayo, S.J.; Coelho, M.A.N.; Ramalho, F.C.; Andrade, I.M. \& Nicolson, D. 1998. Araceae. In Sales, M.F.; Mayo, S.J. \& Rodal, M.J.N. Plantas vasculares das floresta serranas de Pernambuco: Um checklist da flora ameaçada dos brejos de altitude, Pernambuco, Brasil. Recife: Universidade Federal Rural de Pernambuco. 130p.

Mayo, S.J.; Félix, L.P.; Jardim, J.G. \& Carvalho, A.M. 2000. Anthurium bromelicola - a remarkable new species from Northeast Brazil. Aroideana 23: 89-99.

NYBG. 2003. Catalog of vascular plant species of eastern Brazil. Internet URL: www.nybg.org/bsci/ hcol/sebc/araceae.html. Acessado em 2003.

2002. Neotropical flora and mycota catalog. Internet URL: www.nybg.org/bsci/hcol/netr/ araceae.html. Acessado em 2002.

Reitz, P.R. 1957. Aráceas Catarinenses. Sellowia 8(9): 20-70.

Sakuragui, C.M. \& Mayo, S.J. 1999. A new species of Anthurium (Araceae) from south-eastern Brazil. Feddes Repertorium 110(7-8): 535-539.

Schott, H.W. 1855. Pflanzenskizzen. Oest. bot. Wochenbl. 5: 66-86.

Schott, H.W. 1860. Prodromus Systematis Aroidearum: 1-602.

Singh, R.J. 2002. Plant Cytogenetics, CRC Press, Boca Raton. 463p. 
Stearn, W.T. 1993. Botanical Latin. Fourth Edition. A David and Charles Book. London. 546p.

Veloso, E.M., Filho, A.L.R.R. e Lima, J.C.A. 1991. Classificação da vegetação brasileira, adaptada a um sistema universal. Rio de Janeiro. IBGE, Departamento de Recursos Naturais e Estudos Ambientais. 123p.
Viegas, J.; Coelho, M.A.A.; Corrêa, M.G.S. \& Corrêa, L.B. 2006. Taxonomic and Cytogenetic Analysis of Species of the Anthurium (Araceae) Genus Native to the Brazilian Atlantic Forest. Floriculture, Ornamental and Plant Biotechnology: Advances and Topical Issues (1 $1^{\text {st }}$ Ed), Teixeira da Silva JA (ed), pp 669-677. Global Science Books, UK.

\section{ÍNDICE DE EXSICATAS}

s/c (29); A.C. Aguiar 105 (15); V.R. Almeida 1299 (15); Altamiro 8 (7); Alves 2355 (27); Alves 4399 (7); Amado 22 (27); A. Amorim 638, 1366, 1696 (16); D. Araújo s.n. (11); 686, 6142, 6674, 6726, 7829, 9716, 9847, 9921, 10555, (12); 189 (15); 9253, 10611 (23); 3581, 4266, 4406, 4868, 10266 (27); Armond 321 (12); M.A. Assis 349 (32); J.B. Baitello 637 (34); E. Barbosa s.n. (15); K.D. Barreto 2702 (24); F. Barros 665, 666 (27); R.P. Belém 1519 (14); A.P. Bertoncini 726, 727 (34); R.S. Bianchini 43 (32); J.A.R. Bittencourt 117 (7); Boaro 33 (32); W. Boone 611 (6), 962 (13), 576, 708, 956 (16); P. Botelho 50 (15); M. Bovini 411, 690 (15), 787 (21), 451, 481 (33), 532 (34); A.C. Brade 20572 (12), 18573 (15), 8026 (19), 16599 (21), 7189 (24), 16510 (28), 16600 (29), 18745 (32); J.M. Braga 5182 (6), 2615 (7), 287, 732, 744, 1531, 2355, 3115, 3962 (15), 1234, 1242, 1256 (21), s.n. (23), 237, 2193, 2202 (27), 5265 (29), 385, 2747, 3451, 7150 (34); Brüger 22905, 22928, 24690 (25); R. Burle Marx s.n. (32); U. Caramaschi s.n. (12); J.P.P. Carauta 6329, 6736 (15), 1380, 3342 , 2245 (27), 6804 (34); S.M. Carmello 63, 79 (32); A.M. Carvalho 3370 (16); M.B. Casari 206, 861, 1039, 1056, 1150 (12), 913, 1051 (15), 133, 1013 (27), 213, 1138 (34); A. Castellanos 23592 (15), 22750 (27), 23848 (34); L.E. Catharino s.n. (2), 37, 346 (19), 1230, 1234, 1510 (19), 1117, 1344, 1530 (32); C. Chamas s.n. (7), 438, s.n. (16); I. Cordeiro 443 (19), 713 (32); C.M.B. Correia 162 (21), 328 34); Costa 481 (33); D. Cristovan s.n. (32); T.B. Croat 53791 (23), 53676, 53677 (27); N.M.L. Cunha 97 (33); C. Diogo s.n. (21); A.P. Duarte 3736 (29); P.K.H. Dusen 65, 6643, 15250 (19); G. Edwall s.n. (20); G. Eiten 6215 (32); M.C. Espada 1 (27); Eupunino 104 (7); C. Farney 4078 (12), 2419 (13), 2306 (27), 101, 3303 (28), 3081 (34); H.Q.B. Fernandes 1344, 1451, 2962 (5), 1381 (7), 1331 (10), 1566, 2522 (14), 2547 (15), 1267, 1305, 1453 (16); V.F. Ferreira 17 (15), 2109 (23), 2119 (27); M.D.M. Filho 136 (7), 80, 962, 1098, 1108, 1672, 1800, 1935, 2024, 2091 (32); J.B.P. Fonseca s.n. (15); A.P. Fontana 6404 (9); T. Fontoura 205 (12); H. Forero 8749, 8783 (32), 7697 (34); C. Fraga 644 (10); Frazão s.n. (7), s.n. (12), s.n. (15), s.n. (23), s.n. (27); Garcia 104 (33); A.L.S. Gatti 85, 354, 470 (32); A. Gehrt s.n. (32); A. Gentry 928 (21); L.C. Giordano 337, 508, 1306 (7), 547, 1552 (15), 343 (27), 1040, 1418 (32), 1100 (33), 1868, 2018 (34); A. Glaziou s.n. (15), 49 (21); J.M.L. Gomes 484, 485 (15); E.G. Gonçalves 1022 (19), 398 (32); M.R. Gorenstein 136, 143 (32); R. Guedes 20, 188, 191, 289, 290, 291, 296, 346, 395 (27); M.B.G. Guimarães 02 (15); O. Handro 529, 298, 2054 (13), 396 (20), 392, 397, 398, 414, 507 (24), 198, 1245 (32); R.M. Harley 18228 (16); G. Hatschbach 8317, s.n. (2), 1023 (7), 46734, 46771 (15), 6208, 10131, 42507, s.n. (19), 7087, s.n. (24), 2544, 15328, 15331, 16886, 62896 (32); R. Hertel 455, 456 (19); F.C. Hoehne 8076 (13), s.n. (20), s.n. (24), s.n. (32); N.M. Ivanauskas 18 (32); E.L. Jacques 105 (32); J. Jardim 825 (16); P.P. Jouvin 505 (15), 153, 493 (34); E.J. Judziewicz 4090 (16); S.L. Jung 46 (32); H. Kennedy 985 (11), 837, 910 (12), 902 (23); M. Kirizawa 2262 (2), 1741, 1753, 1912 (13), 1551, 1729, 2141 (20), 1748 (24), 589, 1087, 1737, 1746, 1751, 2078 (32), 1684, 2475 (33); V.G. Klein 1076 (15), 915, 1145 (34); L. Kollmann 732, 4940 (7), 3233, 6404, 6705, 6839, 7554, 7556, 7981 (9), 3051, 3892, 4107 (15); T. Konno 220 (7), 166, 315 (34); C. Kozera 1093, 1098, 1176 (7), 759 (19); P.L. Krieger 10504 (12) 11927, 13180 (5), 13180, 13181, 15093, 23218, 23375 (15), 23657 (25); Kuehn 1758 (32); J.G. Kuhlmann 1703, 2313 (32); R. Kummrow 1347 (19); B. Kurtz 160) (15); A.S. Leão 145 (34); H.F. Leitão 34527 (15); L. Leoni 4698, 4773 (15), 99, 1273, 1666 (21), 3095 (22), 3670 (25); T.E. Liene 4024 (12); H.C. Lima 5509, s.n. (21), 4291 (27), 3604 (29), 1724 (34); J.A. Lira 377 (27); A. Löefgren 4065, s.n. (19); Loques s.n. (15); R. Loureiro 16 (15); H. Lüderwaldt 15 (2); P. Maas 3311 (21), 3342 (29); R.A. Macedo 08 (15); O. Machado s.n. (23); F. Madeira 6, 7 (27); M.C.H. Mamede 181 (19), 210, 319, 348, 433 (32); R. Marquete 619, 1019, 1020, 1678 (7), 554, 647, 723, 747, 1160, 1450, 1467, 1958, 1993 (15), 245 (21), 463, 1734, 982, 1061 (28); G. Martinelli 9745 (5), 611, 1231, 3198 (7), 4106 , 4510, 4538, 4550, 5562, 9788 (12), 924 (15), 6074, 8047 (16), 3272, 3340, 9302, 11749, 11786, 12047, 12051, 12964 (21), 13156 (27), 8687, 2509, 13697, 10705 (28), 2510, 13434 (29), 11814 (31), 5737, 14403 (32), 532, 2891, 4195, 8851, 9560, 13283 (34); Martins 295 (32); Mattos s.n. (15); Mattos 12464, 13484, 15082 (32); S.J. Mayo 720 (3), 833 (16), 531 (29); Melo 12, 419 (32); P.H. Miyagi 82 (19); Moura 25 (7); C.F.S. Muniz 08, 37 (20), 249 (32); M. Nadruz 1544 (2), 1450, 1455 (6), 352, 447, 459, 636, 800, 823, 1097, 1103, 1418, 1431, 1432, 1434 (7), 1358, 1360, 1419, 1420, 1421, 1422, 1563 (11), 375, 1424, 1425, 1426, 1427, 1545 (12), 1532, 1546, 1547, 1375, 1397, $1611(14), 355,490,768$, 1138, 1139, 1153, 1156, 1157, 1158, 1161, 1162, 1167, 1168, 1374, 1409, 1410, 1451, 1497, 1530 (15), 1508, 1510, 
1515, 1516 (17), 449 (18), 1485, 1486, 1487, 1488, 1489, 1490, 1551, 1552 (19), 1390, 1550 (20), 368, 393, 417, 418, 437, 438, 510, 734, 735, 737, 742, 752, 769, 1380, 1385, 1386, 1404, 1413, 1416, 1448, 1481 (21), 1538, 1539, 1549 (22), 1537, 1548 (23), 1405, 1473 (24), 1363, 1365, 1478, 1495 (25), 1544 (26), 363, 1355, 1356, 1357, 1362, 1364, 1369, 1372, 1379, 1423, 1428, 1462, 1463, 1464, 1465, 1466, 1467, 1468, 1469 (27), 770, 1378, 1504 (28), 364, 365, 732, 772, 1447, 1449, 1500, 1501 (29), 483, 1527 (31), 1458 (32), 511, 512, 805, 808, 1689 (33), 635, 815, 1322, 1351, 1394, 1395, 1398, 1399, 1400, 1401, 1442, 1443, 1444, 1445, 1446 (34), 1557 (35); M.Y. Nakagomi 29, 34 (19); S.R. Neto 137 (15), 171 (19); C. Nogueira 06, 11 (15); J.V.C. Nunes 07 (12); P. Occhioni 39 (7), 575 (12), 7618 (15), 483 (27), s.n. (21); Oliveira s.n. (32); Oliveira 1091 (7), 352, 1219 (27), 1074 (34); G. Pabst 5655 (29); M. Passamani s.n. (7); Pedra do Cavalo 445, 463, 580, 769, 806 (3); Pedrosa 882 (27), 1390 (34); Pereira s.n. (32); O.J. Pereira 441, 516, 559 (21), 828 (26), 1922 (29); R.B. Pineschi 634 (12); Pinheiro 241, 422 (34); P. Pinto 12 (7), 39 (17); Pinto 44 (47); R.M. Piziolo 78 (7); T. Plowman 10121 (7), 10059 (16); M.L. Pomari 8, 11, 12, 21, 23 (19); S. Profice 37 (21); L.L. Pupatto 4 (19); R.C.C. Reis 39, 49 (34); R. Reitz 2955 (29), 1527, 1976, 2047, 2059, 2145 (32); A.F. Regnell 1297 (30); O.S. Ribas 4329 (2); R. Ribeiro 480 (15), 508 (21), 206, 395, 632, 2049, 2312 (34); Rocha 189 (27), 182 (34); Rodela 103 (15); N.A. Rosa 3878 (32); Rossa 36 (32); L. Rossi 554, 644 (32); C.R. Rubio 55 (32); D. Sampaio 222 (32), 2272 (21); S.A. Santiago 31 (15), 44 (27); Santos 172, 247 (27); Santos 615 (16); C.A. Schwacke 3020 (15); S. Schneider 220, 221 (12), 371, 372 (34); Senna 2 (7); L.L. Silva s.n. (12), 2, 4, 22, 23, 25 (15); Silva 453 (34); R.M. Silva 2406 (2); M.S.F. Silvestre 72 (32); L.B. Smith 1398 (6), 1892 (20); M. Sobral 7015 (32); Souza 15, 65, 247 (19), 167 (32), 904 (34); V.C. Souza 8959, 9025 (7), 12132, 12243 (15), 9202, 9265 (19), 11082 (27); J.F. Stancick s.n. (19); N. Stephan 18678 (12); H.E. Strang 390 (12), 465 (27), 242 (28); D. Sucre 5475 (5), 2545, 5352, 9962 (7), 1520, 1673, 3785, 3906, 4999 (12), 2627, 4307, 4450, 4881, 5073, 5304, 6544, 7227, 8128 (15), 2434, 3196, 3219 (21), 3527, 4944, 4991, 5333, 8131 (23) 5281, 5354, 7974, 9196, 10063 (27), 3183 (29); M. Sugiyama 1150 (2), s.n. (32); L. Sylvestre 719 (15), 307 (21), 419 (32); G. Tessmann 1953 (19); W.W. Thomas 8965 (14); J.M.D Torezan s.n. (19); O. Travassos s.n. (29); A. Usteri s.n. (32); A. Vaz 516, 658 (21); M.D.M. Vianna-Filho 539 (7), 1882, 1928, 3574, 4628 (15); A. Vidal 2094, 2464, 2538 (21), 604, 709, 2694, 5701 (28), 5325 (29); C.M. Vieira 80, 288, 326, 478, 566 (21), 773 (34); S.G. Vinha 116 (16); M.G.L. Wanderley 257 (32). 